UNIVERSIDADE DE SÃO PAULO

FACULDADE DE FILOSOFIA, LETRAS E CIÊNCIAS HUMANAS

DEPARTAMENTO DE LETRAS CLÁSSICAS E VERNÁCULAS

PROGRAMA DE PÓS-GRADUAÇÃO EM LITERATURA PORTUGUESA

\title{
A COMÉDIA CLÁSSICA DE SÁ DE MIRANDA E O DIÁLOGO INTERTEXTUAL COM SEUS PARADIGMAS LITERÁRIOS
}

Martha Francisca Maldonado Baena da Silva

Dissertação apresentada para obtenção do grau de Mestre em Letras ao Programa de Pós-Graduação em Literatura Portuguesa, do Departamento de Letras Clássicas e Vernáculas da Faculdade de Filosofia, Letras e Ciências Humanas da Universidade de São Paulo.

Orientador: Prof. Dr. Francisco Maciel Silveira 
A meu amigo Eduardo E. F. Gomes, por tudo 


\section{AGRADECIMENTOS}

Agradeço, em primeiro lugar e muito especialmente, ao Prof. Dr. Francisco Maciel Silveira, meu orientador, pela confiança em mim depositada e a atenciosa orientação.

Um agradecimento também especial devo à Profa. Dra. Marcia Arruda Franco, pela generosa colaboração, apresentando e cedendo textos que eu desconhecia, e pelos comentários no Exame de Qualificação.

Ao Prof. Dr. Paulo Martins, que, durante toda a minha graduação em Letras, me serviu de referência, por ser o professor que é, generoso na transmissão de conhecimentos, e pelas valiosas sugestões no Exame de Qualificação, muito obrigada.

Ao Prof. Dr. Oswaldo H. L. Ceschin, que tanto me ensinou e tanto incentivou este trabalho, muito obrigada.

Agradeço a todos esses professores maravilhosos, que, de alguma forma, colaboraram para que eu obtivesse os graus de Bacharel e, agora, de Mestre em Letras, ampliando os horizontes do conhecimento no meu mundo: Prof. Dr. Pedro Garcez Ghirardi, Profa. Dra. Elaine Cristine Sartorelli, Profa. Dra. Adriane da Silva Duarte, Prof. Dr. João Angelo Oliva Neto, Prof. Adriano Scatolin, Prof. Dr. Alcides Villaça.

Às minhas amigas, tão queridas, Cristina, Clara, Inez, Leila, Alleid e Cecília, obrigada pelo carinho e pelo apoio.

Ao Edson, meu grande amigo, presente nos momentos mais difíceis, muito obrigada por tudo.

Aos meus filhos e meus pais, agradeço a compreensão e à minha mãe, em especial, a alimentação.

E agradeço, ainda, à Capes, pelo apoio financeiro. 
"Novo Mundo, bom Sá, nos foste abrindo, Com tua vida e com teu doce canto, Nova água e novo fogo descobrindo. Não resplandecia antes o Sol tanto, Não era antes o Céu tão luminoso, Nem nos erguia o esprito em seu espanto.

Tu as fontes abriste, os céus aclaras, Às estrelas dás luz, vida aos amores, Santos amores dũas ninfas raras."

António Ferreira 


\section{SUMÁRIO}

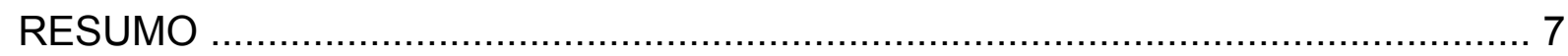

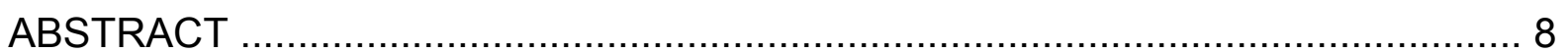

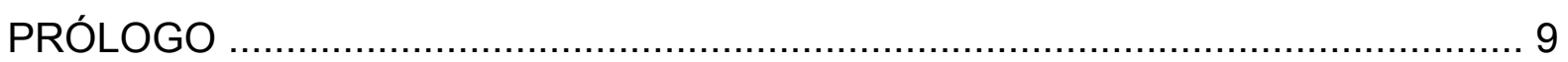

CAPÍTULO I - O mundo e o Portugal de Quinhentos ......................................... 14

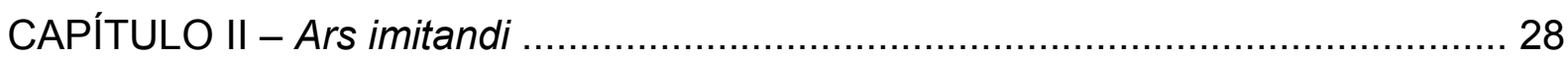

1. A apropriação intencional de textos....................................................... 28

2. "A alusão necessária" .......................................................................... 36

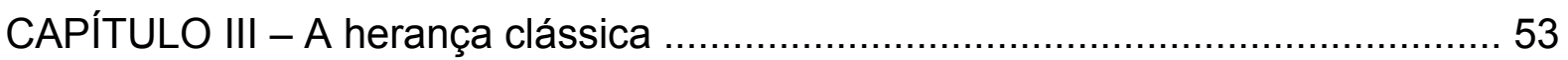

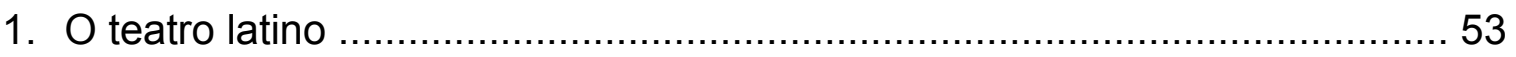

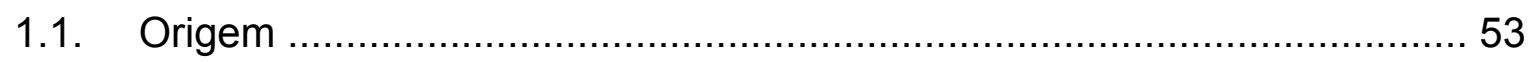

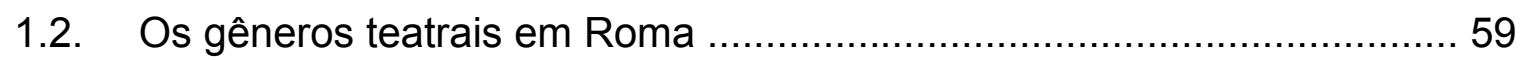

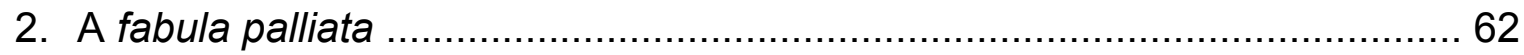

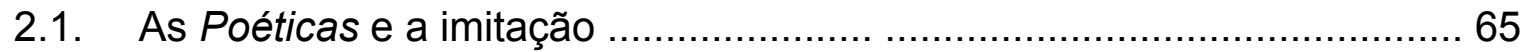

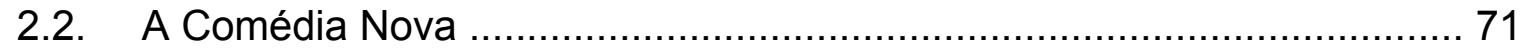

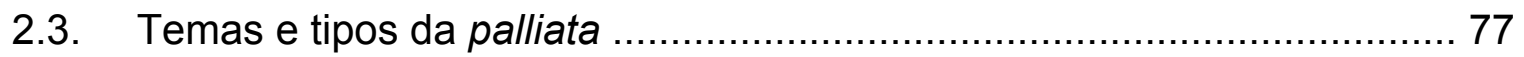

2.4. Categorias e modos da palliata .................................................. 82

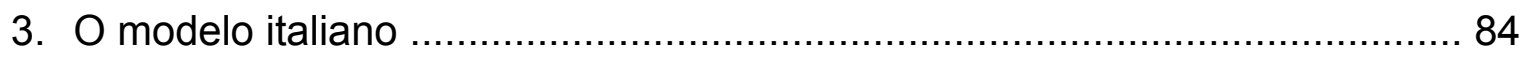

CAPÍTULO IV - Sá de Miranda e o diálogo intertextual com seus paradigmas ...... 95

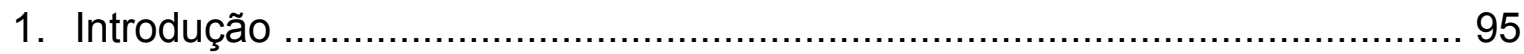

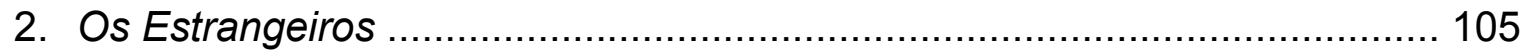

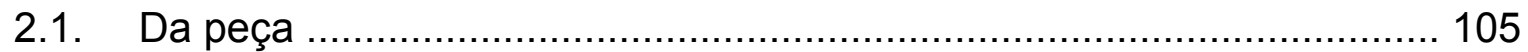

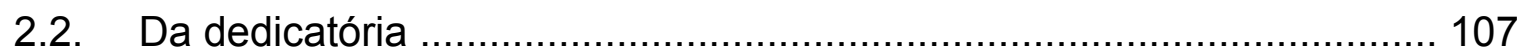

2.3. Do jogo alusivo - o diálogo intertextual ........................................ 113

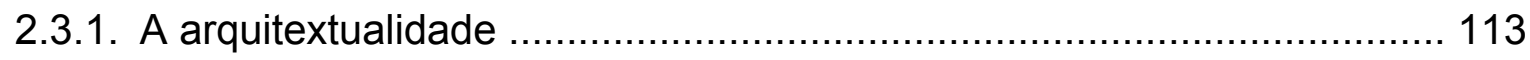

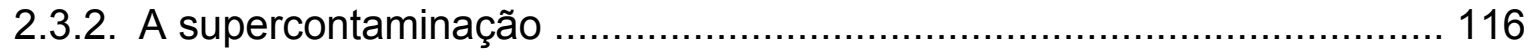

2.3.3. Citações, condensações e paráfrases ............................................ 124

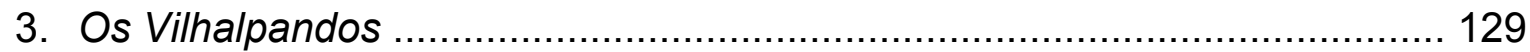

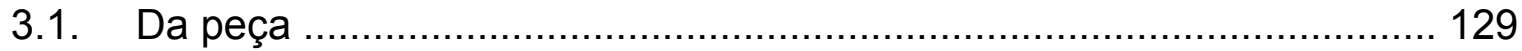


3.2. Do jogo alusivo - o diálogo intertextual ...................................... 132

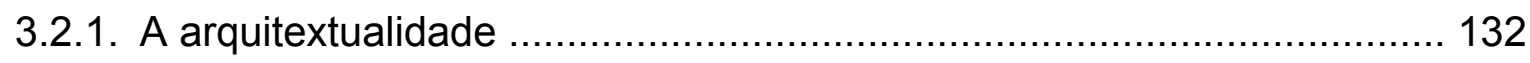

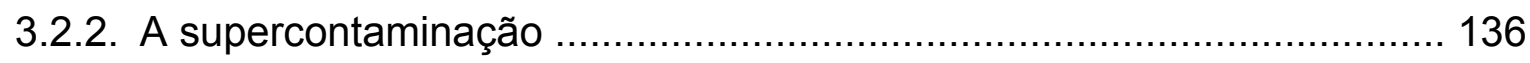

3.2.3. Citações, condensações e paráfrases ........................................... 141

3.2.4. A caricatura da sociedade ..................................................... 150

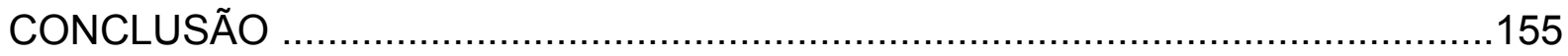

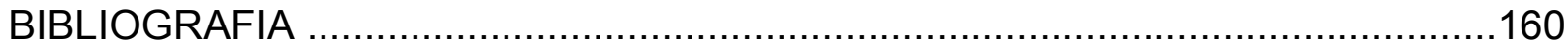

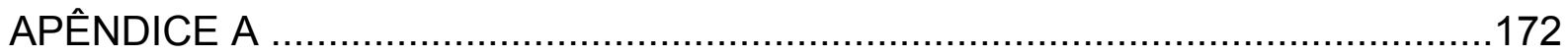

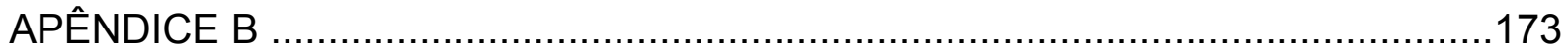




\title{
RESUMO
}

\section{A COMÉDIA CLÁSSICA DE SÁ DE MIRANDA E O DIÁLOGO INTERTEXTUAL COM SEUS PARADIGMAS LITERÁRIOS}

\begin{abstract}
Esta dissertação tem como objetivo examinar o método de composição das comédias de Sá de Miranda e a maneira como o autor utilizou o processo de recriação poética denominado imitatio para promover o diálogo intertextual com seus paradigmas. Trata-se aqui de analisar intertextualmente textos gerados dentro de um contexto histórico-literário específico, em que o imitar era a regra. O autor tem como primeira intenção ao compor esse tipo de obra inserir-se numa tradição poética que aceita e pressupõe a alusão a textos precedentes, ou seja, uma tradição poética autônoma, em que as relações intertextuais se dão de maneira consciente e técnica e a obra de imitação resulta da reelaboração criativa de modelos. O primeiro capítulo vem situar a obra cômica mirandina no contexto histórico-cultural em que foi gerada. O segundo capítulo trata de imitatio e intertextualidade, estabelecendo terminologia e métodos para a análise intertextual, especificamente, de obras que têm a apropiação intencional de textos como princípio de criação literária. O terceiro capítulo apresenta um breve histórico do teatro latino, das origens até o surgimento da fabula palliata, adaptação latina da Comédia Nova Grega, que foi o modelo de comédia imitado pelos poetas renascentistas italianos, cujas obras se tornaram também paradigmas para o poeta português. O último capítulo é dedicado à análise intertextual das comédias de Sá de Miranda.
\end{abstract}

PALAVRAS-CHAVE: Comédia clássica; Sá de Miranda; fabula palliata; imitatio; intertextualidade. 


\section{ABSTRACT}

\section{SÁ DE MIRANDA'S CLASSICAL COMEDY \\ AND DE INTERTEXTUAL DIALOGUE WITH ITS LITERARY PARADIGMS}

The objective of this dissertation is to examine the method of composition of Sá de Miranda's comedies and the way the author made use of the poetic recreation process denominated imitatio to promote the intertextual dialogue with their paradigms. It concerns to the intertextual analysis of texts produced within a specific historical and literary context in which imitating was the rule. The author who composes literary works under this rule has as his first intention to get into a poetic tradition which accepts and presupposes the alusion to preceding texts, i. e., an autonomous poetic tradition in which the intertextual relations take place in a conscious and technical manner and the work of imitation results of the creative reelaboration of the patterns. The first chapter comes to situate Sá de Miranda's comic work in the historical and cultural context in which it was generated. The second chapter deals with imitatio and intertextuality, establishing terminology and methodology for intertextual analysis of specifically literary works which have the intentional appropriation of texts as literary creation principle. The third chapter presents a brief history of the Roman theater, from its origins up to the arising of the fabula palliata, the Roman adaptation of the Greek New Comedy, which was the model of comedy imitated by the Italian poets of the Renaissance, whose works became paradigms to the Portuguese poet too. The last chapter is dedicated to the intertextual analysis of Sá de Miranda's Comedy.

KEY WORDS: Classical Comedy; Sá de Miranda; fabula palliata; imitatio; intertextuality. 


\section{PRÓLOGO}

A idéia de investigar a comédia clássica portuguesa brotou da vontade de unirmos, num único trabalho, estudos que compreendessem duas áreas de nosso maior interesse: a literatura latina, à qual vínhamos nos dedicando na graduação, com a literatura portuguesa, objeto de simpatia que nos levou à pós-graduação.

Principiávamos nossa pesquisa sobre o teatro clássico português, mais precisamente sobre as comédias do introdutor do Classicismo em Portugal, Sá de Miranda, quando observamos que poucos eram os estudos dedicados à comediografia desse autor. Posteriormente, ao buscarmos outros autores do Classicismo português que enveredaram pelo campo dramático, a saber, Jorge Ferreira de Vasconcelos, António Ferreira e Camões, observamos que escassos e superficiais eram os estudos, não só da obra teatral de Sá de Miranda, mas de toda aquela comédia que surgira da imitação dos clássicos, antigos e renascentistas.

A vontade de investigar profundamente toda a comédia clássica portuguesa foi grande, mas o prazo curto para a conclusão de um trabalho como este impôs limites à nossa ambição. Diante deste fato, nosso primeiro passo foi selecionar, dentre os textos que se ofereciam, aqueles que seriam nosso objeto de estudo. Optamos, primeiramente, pelas duas comédias de Sá de Miranda, Os Estrangeiros e Os Vilhalpandos, por ser seu autor pioneiro na composição de comédias nos padrões clássicos, somadas às duas de António Ferreira, as comédias de Bristo e do Cioso, por encaixarem-se perfeitamente à fôrma clássica, ou seja, por seguirem estritamente as regras e princípios de imitação preestabelecidos e reproduzirem com fidelidade as fórmulas e convenções da comédia latina, já retomada na Itália renascentista.

As comédias de Jorge Ferreira de Vasconcelos e de Camões, por não corresponderem, no aspecto formal, ao modelo latino, foram deixadas de lado logo de início. Embora ambos façam uso de alguns dos topoi da Antigüidade, desprezaram regras e convenções que regem o gênero. Além disso, suas comédias 
foram visivelmente influenciadas pela cultura e pela literatura humanista espanhola, especialmente no que diz respeito à obra teatral de Ferreira de Vasconcelos.

Posteriormente, por sugestão da banca no Exame de Qualificação, decidimos excluir de nosso rol de comédias a serem analisadas as de António Ferreira e focar nosso estudo nos processos de composição e recriação poética de Sá de Miranda. As primeiras décadas do século XVI foram um momento de experiências, uma fase do Renascimento marcadamente criativa, durante a qual se aprendia a "arte de imitar" praticada pelos antigos. Por ser esta a fase vivenciada por Sá de Miranda, durante sua permanência na Itália, interessa-nos mais especificamente o processo de composição das comédias mirandinas e a maneira como o autor utilizou o processo de recriação poética denominado imitatio para promover o diálogo intertextual com seus paradigmas. Já António Ferreira viveu uma outra fase do período clássico. Ele participa de um momento em que já começavam as discussões que levariam, no século seguinte, à formulação de princípios e de uma doutrina para a arte da imitação. Certamente, aprendeu muito com os erros e os acertos do mestre Sá de Miranda, e seu teatro cômico vale, sem nenhuma dúvida, uma investigação aprofundada, mas esta deixaremos para um próximo trabalho.

O caráter intertextual das obras investigadas é evidente, sendo produto de um período cultural em que a apropriação intencional de obras alheias era a regra. A erudição fazia-se qualidade essencial a quem produzia e a quem consumia tal obra intelectual, posto que se evocava uma tradição já a partir dos títulos das obras. A fôrma era a mesma utilizada pelos poetas cômicos latinos, a da fabula palliata imitação da Comédia Nova Grega. Encontrar as fontes, ou paradigmas literários, das peças de Sá de Miranda entre as comédias latinas e renascentistas apresentou-se como primeira necessidade, mas outras questões se impunham à investigação: Por que o modelo latino foi o escolhido para a imitação e não o grego aristofânico? Como se deu a imitação nas comédias do Renascimento, primeiramente na Itália e, pouco depois, em Portugal? De que forma foram compostas pela pena de Ludovico Ariosto - cuja influência sobre sua obra o próprio Sá de Miranda confessa - aquelas primeiras comédias regulares da Idade Moderna? Como se processou o jogo intertextual na comédia italiana e qual sua influência efetiva na composição das comédias portuguesas? 
Sabendo que a literatura imitativa pressupõe textos precedentes de alguma forma evocados, ou seja, que da literatura imitativa resultam intertextos que pressupõem paradigmas literários e que o valor dessas obras reside justamente no reconhecimento pelo leitor dos textos que Ihes serviram de base, questionamo-nos ainda quanto ao público a que se destinavam essas obras: havia em Portugal, como na Itália, um público suficientemente erudito para apreciar o novo gênero introduzido por Sá de Miranda?

É sabido que já existia em Portugal uma tradição teatral, representada pelos autos e farsas vicentinos, quando a Comédia Clássica se apresentou à platéia portuguesa. Que fatos ou fatores encorajaram Sá de Miranda a invadir um território consagrado a Gil Vicente e seus seguidores, empunhando uma bandeira estrangeira - a ação de suas peças se passa na Itália, seus personagens são italianos e estrangeiros em geral - e portando um ideal artístico e, especificamente, um modelo de teatro tão distante daquele conhecido e apreciado na tradição portuguesa? $\mathrm{A}$ busca de respostas a estas e tantas outras indagações decidimos dedicar nosso tempo e esforços.

Definidos os textos que seriam investigados, passamos à identificação de todos os seus possíveis paradigmas, seguindo as informações dadas pelo próprio autor em seus textos. Na dedicatória ao Infante Cardeal Dom Henrique, que precede a comédia Os Estrangeiros, Sá de Miranda refere-se a Plauto, Terêncio e Ariosto como modelos, sem indicar quais de suas obras, o que significa que todas as vinte e seis restantes comédias latinas - vinte de Plauto e seis de Terêncio - e as cinco de Ariosto poderiam ter servido de base. Considerando que, durante sua passagem pela Itália, Sá de Miranda deve ter conhecido as comédias de outros autores italianos, nomeadamente Maquiavel e Bibbiena, decidimos incluí-las como modelos não confessados pelo autor. Ou seja, consideramos como possíveis paradigmas, além das comédias latinas, as comédias clássicas italianas compostas e representadas ou publicadas antes da composição das comédias mirandinas. Levamos em conta, ainda, a tragicomédia espanhola $A$ Celestina, cuja personagem principal deixou suas marcas na alcoviteira da comédia italiana La Lena, de Ariosto, um dos modelos para Os Vilhalpandos de Sá de Miranda, e que viria, pouco depois, influenciar a caracterização do alcoviteiro da Comédia de Bristo, de António Ferreira. 
Identificados os possíveis paradigmas, dedicamo-nos ao estudo do teatro antigo e renascentista, da imitação e dos processos de composição da literatura "em segundo grau", na Antigüidade e no Renascimento, e das teorias e dos métodos para análise das relações intertextuais para, por fim, procedermos a uma análise minuciosa, ainda que não exaustiva, desses textos portugueses, visando não tão somente determinar os paradigmas Iterários de Sá de Miranda, mas apreender os sentidos que o jogo intertextual por ele praticado possa ter promovido.

O resultado de nossa pesquisa encontrar-se-á organizado, neste trabalho, em quatro capítulos precedidos deste prólogo. O primeiro capítulo, de caráter introdutório, pretende situar o autor e sua obra no ambiente e no contexto históricocultural em que surgiram. O segundo capítulo tratará da "arte de imitar", da apropriação intencional de textos e dos processos de composição imitativa, da intertextualidade, da terminologia e dos métodos para a análise intertextual. No terceiro capítulo, apresentaremos um breve histórico do teatro latino e de seus antecedentes, a encaminhar para o modelo reproduzido por Plauto e Terêncio e, posteriormente, pelos poetas do Renascimento, a fabula palliata. O modelo italiano, somado ao grupo de predecessores do poeta português, é também observado neste capítulo, assim como as Poéticas antigas, referências obrigatórias no estudo de obras clássicas, modernas ou antigas, desde o que concerne à divisão dos gêneros literários até às regras para a boa imitação. O último capítulo será dedicado à análise intertextual das comédias de Sá de Miranda.

Traduzimos todas as citações de textos em língua estrangeira. Com exceção dos prólogos das comédias de Ariosto, cujo texto citamos no original e a nossa tradução segue em nota de rodapé, todas as outras citações aparecem traduzidas no corpo do trabalho. Dos textos em latim para os quais encontramos tradução em português já publicada, citamos esta tradução; para os que não encontramos, a citação tem a nossa própria tradução; em ambos os casos, apresentamos o texto original, sempre que possível, ${ }^{1}$ em nota de rodapé, padronizando a grafia do $u$ e do $i$ consonantais sempre em $u$ e $i$, e não $v$ e $j$, como se apresentam em algumas das edições que utilizamos. Não modernizamos a ortografia dos textos em português

\footnotetext{
${ }^{1}$ Não dispúnhamos de todos os textos citados no original.
} 
desatualizado, nem modificamos a grafia de vocábulos de nossa língua que se apresentam sob formas variantes nas citações, nem nelas corrigimos qualquer erro gramatical, ou seja, mantivemos os textos citados exatamente como se apresentam no original, e já o avisamos aqui, evitando imprimir nas citações uma imensa série de sic que, pensamos, dificultaria a leitura.

Incluímos, ao final do trabalho, como apêndices, duas edições críticas, uma semidiplomática e outra modernizada, que fizemos da carta-dedicatória endereçada ao Infante Cardeal Dom Henrique, constante no Manuscrito Asensio (Biblioteca Nacional de Lisboa), apógrafo produzido em torno de 1540, correspondente ao texto da edição de 1559 da comédia Os Estrangeiros, por conter este dados importantes para a compreensão do processo criativo do poeta. ${ }^{2}$

Nosso estudo pretende ser mais analítico do que crítico, muito embora seja difícil não cair na tentação de tecer juízos de valor, colocando os modelos latinos e italianos como pedra de toque para a avaliação das comédias portuguesas. Nosso interesse reside principalmente na caracterização da comédia clássica recriada por Sá de Miranda, na descoberta de seus paradigmas literários, dos métodos de composição e dos processos de imitação levados a efeito em seus textos, tendo em mente que a criação "em segundo grau" deve ser sempre uma reelaboração criativa de seus modelos.

\footnotetext{
${ }^{2}$ Uma cópia do manuscrito foi-nos gentilmente confiada pela Profa. Dra. Marcia Arruda Franco, cujo trabalho acerca das duas versões da dedicatória, citado ao longo desta dissertação, também foi de grande ajuda na elaboração de nosso trabalho.
} 


\title{
O mundo e o Portugal de Quinhentos
}

\begin{abstract}
"Uma geração literária distingue-se e caracterizase das demais, não só por um conjunto peculiar de categorias expressivas que lhe dão forma, mas por uma atitude especial perante a vida e o mundo que lhe dão substância."
\end{abstract}

Segismundo Spina ${ }^{3}$

O começo do século XVI, início da Idade Moderna, é um momento de grande agitação e de mudanças na Europa, que, se por um lado, é marcado pela efervescência cultural e pelos avanços científicos, por outro, eivado pelo hedonismo, traz as marcas das disputas pelo poder e da turbulência nas esferas política e religiosa. É um momento em que se evidenciam as contradições do mundo moderno que se inicia e que à absoluta Verdade pregada pela Igreja se contrapõem as dúvidas geradas pela percepção dessas contradições - o que se prega não é o que se faz. Instala-se a chamada "crise do absoluto"4 - crise das certezas medievais que serão contestadas no Renascimento e que se verá refletida na literatura do período em forma de critica à sociedade e às suas instituições.

Assim, enquanto França, Espanha e Alemanha (Sacro Império RomanoGermânico) disputam o poder sobre a opulenta Itália - a privilegiada posição geográfica da península contribuía para que mantivesse o monopólio do tráfico de especiarias pelo Mediterrâneo, gerando a invejada riqueza que possibilitou a grande e fausta produção artística do Renascimento -, Lutero revoluciona o cristianismo com a Reforma, contestando a autoridade moral da Igreja; a ciência moderna nasce, propondo métodos e procedimentos científicos válidos até nossos dias; Portugal

\footnotetext{
${ }^{3}$ A cultura literária medieval. São Caetano do Sul: Ateliê, 1997, p. 41.

${ }^{4} \mathrm{O}$ tema foi tratado pelo professor Pedro Garcez Ghirardi no curso de pós-graduação da FFLCH-USP "Crise do absoluto e criação poética: o Orlando Furioso de Ariosto", ministrado no segundo semestre de 2004.
} 
investe contra "mares nunca d'antes navegados", descobrindo novas terras, expandindo o reino e trazendo riquezas para o país.

Em meio a esse amontoado de acontecimentos, um novo padrão do Belo se estabelece e espraia daquela Itália invadida e saqueada por estrangeiros. A Antigüidade Clássica ressurge como paradigma de excelência estética e renasce nas novas composições poéticas nela espelhadas.

Não há, no entanto, que se pensar no Renascimento como um abalo sísmico que acontece repentina e inesperadamente, nem que as transformações se dão da mesma forma e ao mesmo tempo por toda a Europa. As mudanças decorrem de um longo processo do qual o Renascimento é, poderíamos dizer, o termo. ${ }^{5}$

Durante a Idade Média, o mundo não deixara de evoluir. Assiste-se ao longo de seus séculos ao aparecimento de conceitos como o de individualidade e de nação; à expansão do ensino universitário; à preparação para o capitalismo, com o desenvolvimento da indústria e a organização do comércio; à urbanização da Europa. Mas, se com o progresso vêm riqueza e conforto, vêm também os problemas provocados pela mudança de valores, como observa Spina, dos quais nem os representantes da Igreja, com toda sua pretensa santidade, escapam:

O desenvolvimento econômico acarreta no século XIV um contraste violento de valores: ao lado do idealismo cavaleiresco e dos ideais ascéticos surge a força poderosa do DINHEIRO [...]: em oposição às proezas desinteressadas da Cavalaria surge a consciência aguda do TRABALHO; à ânsia de fama e santidade se sobrepõe o ideal hedonístico de gozar amavelmente a vida.[...] Os grandes burgueses (a classe rica), [...] entregam-se freneticamente ao luxo e aos prazeres da vida ...

Esse estado de coisas evolui até a instalação da crise que se observa no Renascimento. E a degradação dos costumes e a corrupção do clero estarão entre as mazelas estampadas nas páginas de uma literatura que, se por princípio é bela e culta, é, além disto, uma forma de contestação.

Quanto ao resgate da Antigüidade Clássica - de sua cultura e seus valores -, é bom lembrarmos que ela nunca esteve completamente soterrada (os textos dos

\footnotetext{
${ }^{5}$ Cf. BUESCO, M. L. Carvalhão. Aspectos da herança clássica na cultura portuguesa. Lisboa: Instituto de Cultura Portuguesa - Secretaria de Estado da Cultura, 1979, p. 22.

${ }^{6}$ Op. cit., p. 95 . Grifos do autor.
} 
antigos gregos e romanos não reapareceram numa descoberta de arqueólogos no Renascimento do Quinhentos, eles foram preservados nas bibliotecas dos mosteiros) e sobreviveu durante a Idade Média, ainda que como resíduo cultural, "atenuada e descaracterizada pela Igreja". ${ }^{7}$ Paralelamente ao desenvolvimento de uma literatura influenciada pela cultura cristã, a literatura dos antigos era estudada nas escolas e mosteiros e, muitas vezes, evocada em novos textos. Segundo Buescu, Cícero, Sêneca, Ovídio e Virgílio são autores "que a Idade Média não chegara a esquecer." ${ }^{8}$ Spina afirma que Ovídio foi o best-seller do século $\mathrm{XII}^{9}$ e Curtius que, para a Idade Média, tanto quanto para o último período da Antigüidade, Virgílio foi "o altíssimo poeta" ${ }^{10}$ Nunca houve, na verdade, uma ruptura da Idade Média com a Antigüidade. Houve, sim, uma "Antigüidade medieval”, que é como a Idade Média via a Antigüidade, e uma Idade Média latina que "é a desgastada estrada romana que conduz da Antiguidade ao Mundo Moderno."11 Por essa estrada, de alguma forma preservada, pôde chegar o espírito humanístico, característico dos antigos, que animou o Renascimento. Pode-se afirmar isso da Europa como um todo, como uma unidade cultural, visto que suas raízes históricoculturais transmitem um legado comum, o que não quer dizer que todos os herdeiros do Império Romano tenham feito uso de sua herança da mesma maneira. Nas palavras de Buesco, a esse legado, que ela chama de "denominador comum",

... podemos designar por herança clássica, sem que, no entanto, essa unidade e essa herança assumam o aspecto duma identidade despersonalizadora. Efectivamente, cada sociedade joga com a sua própria formulação do aparato cultural e a herança comum pressupõe a utilização dum espólio livre de cláusulas e orientado segundo o estatuto autônomo de cada comunidade cultural. ${ }^{12}$

\footnotetext{
${ }^{7}$ SPINA, op. cit., p. 16.

${ }^{8}$ Op. cit., p. 22.

${ }^{9}$ Op. cit., p. 77. Devemos lembrar que o século XII viveu o segundo Renascimento, algo parecido com o do Quinhentos no que toca à retomada dos textos clássicos antigos. O primeiro, foi o Carolíngio, entre o final do século VIII e o começo do século IX, marcado pela "reconstituição gramatical dos textos antigos." (ibidem, p. 68)

${ }^{10}$ CURTIUS, E. R. Literatura Européia e Idade Média Latina. São Paulo: Hucitec: Edusp, 1996, p. 50.

${ }^{11}$ Ibidem, p. 51.

${ }^{12}$ Op. cit., p. 9.
} 
Não se pode, pois, pensar em um Renascimento unívoco. Há, antes, que se pensar, conforme Silveira,

... que tal conceito deriva, na verdade, de vários renascimentos que ocorrem, não simultaneamente, nos diversos países e que atingem ou não sua plenitude, com peculiaridades e idiossincrasias que merecem atenção. ${ }^{13}$

Assim, se na Itália o Renascimento é precedido pelo movimento humanista, que, inspirado na cultura clássica e "mercê das preocupações filológicas de Francesco Petrarca (1304 - 1374), conquistou o norte, o sul e o oeste europeus"14, o Renascimento português, animou-o um espírito prático e empreendedor, que fez desenvolver a ciência náutica e levou o reino, com as conquistas ultramarinas, à expansão territorial, ao avanço do comércio marítimo e ao enriquecimento. Muito contribuiu para o pragmatismo português a posição do pequeno país no continente: de um lado, apartado da "Europa culta" pelos Pirineus - a cultura e o pensamento humanista lá chegaram aos poucos e lentamente atravessando a Espanha - e de outro, aberto ao oceano, única possibilidade de expandir seus domínios. "Faltavanos o trigo, precisávamos de ouro - e sobrava-nos energia combativa para os ir buscar aonde abundavam", explica Cidade. ${ }^{15}$

Silveira lembra que, em Portugal, "é só no zênite dos descobrimentos marítimos que se acentua o contato do País com os meios humanistas além Pirineus"16 e que "só a partir de 1534 [...] se pode apurar e rastrear historicamente uma corrente humanística, metodológica e doutrinal." ${ }^{17}$ Antes disso, nas palavras de Cidade, não se ouvem "mais do que tímidos, quase apagados ecos das novidades doutrinárias" 18 que vinham de fora.

\footnotetext{
${ }^{13}$ SILVEIRA, Francisco Maciel. Introdução. In: Poesia clássica: literatura portuguesa. São Paulo: Global, 1988, p. 12.

${ }_{14}$ Ibidem, p. 9-10. O autor assinala as peculiaridades do Renascimento nas diversas regiões européias: "A fruição existencial que caracterizava a Itália não repercutiu nos povos do norte, que tendiam a ver os problemas da vida por um prisma religioso e moral. A 'paganização' italiana não chegou também a atingir Portugal e Espanha, que não só se mantiveram presos ao dogmatismo da fé católica, como não vieram a aderir totalmente à onda de críticas que enfraqueceram a autoridade da Igreja." (p. 12)

${ }^{15}$ CIDADE, Hernani. Lições de Cultura e Literatura Portuguesa (séculos XV, XVI e XVII). 7. ed.

Coimbra: Coimbra Editora, 1984, v. 1, p. 116.

${ }_{17}^{16}$ Loc. cit., p. 13.

17 Ibidem, p. 14.

${ }^{18}$ Loc. cit., p. 156.
} 
Em Portugal, assiste-se, pois, a um Renascimento que começa pelo desenvolvimento científico, voltado para as necessidades expansionistas e comerciais do reino e que somente pelo "rigoroso espírito de exactidão" ${ }^{19}$ pode ser comparado ao que se assiste na "Europa culta", como bem observa Picchio:

O espírito científico e o rigor analítico com que em Itália os homens da Renascença evocam o mundo antigo são os mesmos que assistem o homem português na construção de um mundo novo; enquanto em Florença e em Roma se estudam os velhos códices recuperados, no ermo de Sagres compulsam-se portulados e roteiros. As grandes navegações, a descoberta de novas terras, paisagens e tipos humanos conferem ao Renascimento lusitano um inconfundível caráter nacional, repassado de exotismo e de consciência de Império. ${ }^{20}$

Nem por isso se deve pensar num Portugal iletrado. D. Dinis $(1279$ - 1325) já havia fundado os Estudos Gerais (uma espécie de Universidade) em 1290. E, daí em diante, a educação superior seria sempre incentivada nos reinados seguintes. Desde o reinado de D. Manoel (1495 - 1521), estudantes portugueses eram mantidos em universidades estrangeiras e, depois, professores estrangeiros foram convidados a lecionar na Universidade portuguesa. (Naturalmente, esse ensino se destinava a uma elite favorecida pela corte, o que não diferia - nem diferirá - da educação oferecida em outros centros e em outros tempos.) É sabido que o rei D. Duarte $(1433-1438)^{21}$ cultuou as letras, promoveu traduções, organizou a primeira biblioteca de que se tem notícia em Portugal, onde não faltaram Cícero, Sêneca, Aristóteles, entre outros, ${ }^{22}$ e que a cultura na corte foi sempre incentivada. Mas não se pode esquecer, como assevera Cidade, que a "corte era de um catolicismo severo e estreito" 23 e que todo conteúdo cultural vindo de além Pirineus passava pelo filtro religioso e esbarrava na enraizada cultura tradicional ibérica. Mesmo a poesia do Cancioneiro Geral de Garcia de Resende, que expressa já “incipientes

\footnotetext{
${ }^{19}$ CIDADE, op. cit., p. 128.

${ }^{20}$ PICCHIO, Luciana Stegagno. História do teatro português. Lisboa: Portugália, 1964, p. 114.

21 As datas que seguem os nomes dos reis neste parágrafo indicam o período de seus reinados.

${ }^{22}$ Cf. CIDADE, loc. cit., p. 92-93.

${ }^{23}$ Ibidem, p. 158.
} 
ares humanistas" e "influências de leituras greco-latinas" 24 , além de petrarquistas, mantém a temática medieval e caracteriza-se como "mero entretenimento para ócios ilustrados."25

Não é de causar estranheza, assim, que os poetas do Classicismo português, em pleno século XVI, ainda se exercitassem na "medida velha" ${ }^{26}$ e nos temas medievais, sem muito se interessarem pelas novas fôrmas poéticas e pela renascente estética clássica, enquanto essas novidades vinham ganhando forças na Itália desde o início do século XIV, com Dante (1265 - 1321) e a retomada do modelo épico - A Divina Comédia, embora não narre feitos heróicos, traz de volta o paradigma homérico, antes seguido por Virgílio, que é personagem do poema, evocando a tradição clássica - e com a renovação formal da lírica implementada por Petrarca.

Gêneros, formas e processos de criação da poética clássica, retomados pelos italianos, marcariam, no Quinhentos, a literatura de alguns dos maiores poetas do Classicismo português: Sá de Miranda (1487 - 1558), o introdutor; António Ferreira (1528 - 1569), o doutrinador; e Camões (1524 ou 1525 - 1580), o grande nome do movimento em Portugal. Mas dentre estes, somente António Ferreira fugiria à tradição ibérica, aderindo totalmente à clássica. Para os outros, a "medida nova", 27 trazida da Itália por Sá de Miranda, veio enriquecer a poesia, mas a tradição ibérica e o pensamento medieval permaneceriam.

A relativa liberdade criativa de que gozavam os escritores no tempo dos papas mecenas (entre a segunda metade do século XV e primeira do XVI) também permitiu que fantasia e paganismo se misturassem a elementos do mundo cristão nas fábulas dos poetas e que a crítica fosse uma das marcas da literatura desse período. Assim, tanto o universo maravilhoso de poemas como o épico Orlando Furioso (1516), ${ }^{28}$ de Ludovico Ariosto, quanto "pilhérias" como as de Erasmo de

\footnotetext{
24 SILVEIRA, op. cit., p. 16.

${ }^{25}$ Ibidem.

26 “No século XVI deu-se a designação de 'medida velha' aos metros e fôrmas poéticas que, de origem ibérica, foram exercitadas pelos poetas do Cancioneiro Geral (1516)." Ibidem.

27 “'Medida nova' é o rótulo que se aplicou à inovação métrica (o verso decassílabo), às combinações estróficas (terceto, oitava-rima) e fôrmas poéticas (soneto, carta, elegia, canção, écloga) que, de origem italiana ou greco-latina, vestiram à clássica a poesia quinhentista." Ibidem, p. 19.

${ }^{28}$ Essa é a data do aparecimento do poema, incompleto. A edição definitiva é de 1532.
} 
Rotterdam, ${ }^{29}$ no seu Elogio da Loucura (1509), eram toleradas em solo italiano, ${ }^{30}$ enquanto que, em Portugal, o fanatismo religioso que dominava o pensamento de seus governantes e, em seguida, a Inquisição, vieram impor limites à criatividade e à sensibilidade artística. Lembremos que Camões, n'Os Lusíadas, precisou esclarecer - talvez pela própria mão do censor Bartolomeu Ferreira - que os deuses dos pagãos não eram mais do que soluções estéticas, que o Belo podia ir além da religião.

No que concerne ao gênero dramático, é a comédia nos moldes clássicos, imitação dos latinos Plauto e Terêncio, que vem inaugurar o teatro da Idade Moderna. Surge da pena de Ariosto, em Ferrara, na Itália, em 1508, com a representação de sua primeira comédia, La Cassaria, que seria o paradigma do gênero tanto para os próprios italianos, quanto, mais tarde, para o restante da Europa. Mas foram os portugueses os primeiros a seguirem os passos dos italianos e a comporem comédias na fôrma clássica. Dentre eles, dois nomes se sobressaem: Francisco de Sá de Miranda (1487-1558) e António Ferreira (1528-1569), seu discípulo e seguidor.

É na bagagem de Sá de Miranda, de retorno da Itália, em 1527, que a comédia clássica chega a Portugal. A data marca também o início do Classicismo na terra de Camões, o poeta que mais alto elevou a poesia clássica portuguesa. Mas é Sá de Miranda quem vem introduzir a "medida nova" e a imitatio, o processo de recriação poética que abriu caminhos para o surgimento de obras literárias como as de Camões e daquele que viria a ser o teórico do Classicismo português, António Ferreira. Por seis anos, ${ }^{31}$ Sá de Miranda esteve em contato com as novas tendências da arte, com o novo ideal estético do Renascimento - o retorno aos

\footnotetext{
${ }^{29}$ O próprio Erasmo denomina assim sua sátira, já se prevenindo de detratores: "Na verdade, haverá maior injustiça do que, sendo permitida uma brincadeira adequada a cada idade e condição, não poder um literato pilheriar, principalmente quando a pilhéria tem um fundo de seriedade, sendo as facécias manejadas apenas como disfarce, de forma que quem as lê, quando não seja um solene bobalhão, mas possua algum faro, encontre nelas ainda mais proveito do que em profundos e luminosos temas?" Tradução de Alex Marins. São Paulo: Martin Claret, 2004, p. 12.

${ }^{30}$ A tolerância da Igreja na Itália para com as críticas expressas na literatura do período acabou por exercer alguma influência em Portugal quanto à aceitação do novo ideal poético e à recepção das comédias mirandinas, como se verá no Capítulo IV deste trabalho.

${ }^{31}$ Earle (Traição e Amargura nas comédias de Francisco de Sá de Miranda, 2003) aponta a possibilidade de que a ida do poeta para a Itália, que tem por data o ano de 1521, tenha ocorrido antes disso e, assim, sua permanência em solo italiano teria sido mais longa, mas não indica nenhum fato concreto que corrobore sua posição.
} 
modelos greco-latinos - e no convívio com artistas que praticavam esse ideal e deles recebeu inspiração para o projeto de renovação da poesia portuguesa, que pôs em prática assim que voltou à pátria, aplicando logo a "medida nova" e a imitatio, levando à cena, em 1528, sua primeira comédia, Os Estrangeiros, que muito agradou a D. Henrique, o infante cardeal.

Contudo, Sá de Miranda teve que explicar o que era essa técnica de composição que permitia "furtos" a obras precedentes e a que vinha esse novo gênero de teatro, a comédia, que tanto se distanciava daquela da tradição teatral portuguesa, fundada nos autos e farsas vicentinos, e o fez numa dedicatória ao cardeal, que precede sua primeira comédia, e em seu prólogo, ${ }^{32}$ numa espécie de capitatio beneuolentiae, que não parece ter comovido senão um número restrito de intelectuais. "Era a primeira vez que a Comédia de intriga e de caracteres escrita em prosa portuguesa, culta e aprimorada, se oferecia no palco. Quão diferente do teatro de Gil Vicente simples, popular e vasado [sic] naqueles versos correntes da redondilha, onde a graça esfusiava [sic] a jorros", lembra Remédios. ${ }^{33}$

O Classicismo já ia avançado na Itália, fazendo reviver gregos e latinos através de seus textos exemplares, entre eles os de Plauto e Terêncio, quando Sá de Miranda lá desembarcou, em $1521,{ }^{34}$ a fim de completar sua educação de humanista e de aprender as técnicas daquela arte de recriação literária, praticada e esquematizada por gregos e romanos antigos e retomada pelos italianos.

Desde a segunda metade do século $X V$, as comédias latinas já eram encenadas na Itália, mas no original, em latim. ${ }^{35}$ A princípio, o que se desejava era trazer de volta à cena os autores clássicos. Depois, esses autores passaram a ser traduzidos para o italiano vulgar. Em 1486, em Ferrara, foi representada a primeira tradução de uma comédia latina, a comédia d' Os Menecmos, de Plauto.

\footnotetext{
${ }^{32}$ Tanto a dedicatória como o prólogo de Os Estrangeiros serão analisados no Capítulo IV deste trabalho.

${ }^{33}$ REMÉDIOS, J. Mendes dos. As comédias de Sá de Miranda. In: Revista da Universidade de Coimbra. Vol. XI. Coimbra: Imprensa da Universidade, 1933, p. 1050.

${ }^{34}$ Mais uma vez lembramos que o estudioso das comédias mirandinas T. Earle não concorda com essa data.

${ }^{35}$ Segundo María Teresa Navarro Salazar, em 1429 foi descoberto o Codice Orsiniano, contendo doze comédias de Plauto desconhecidas durante a Idade Média e, em 1433, outro códice com os comentários de Donato sobre as comédias de Terêncio é encontrado. Os comentários de Donato foram publicados em 1470 e com eles os italianos aprenderam "como construir uma comédia latina à maneira de Terêncio.” Introducción. In: ARIOSTO. El Nigromante. Barcelona: Bosch, 1976, p. 40.
} 
Os italianos continuaram a representar traduções até que Ariosto passou a imitar aquelas comédias, seguindo as regras e os princípios da imitação "em segundo grau", ${ }^{36}$ de que trata Horácio, e construindo seu texto como uma montagem de fragmentos de diversas comédias latinas e, também, de obras consagradas da literatura italiana, como o Decamerão, de Boccaccio. A cena era ambientada fora da Itália, numa cidade grega, como faziam Plauto e Terêncio ao imitar o modelo grego, a Comédia Nova, mas o texto era entremeado de fatos do cotidiano italiano e recheado de críticas aos costumes da época, para torná-lo atual, reconhecível e apreciável à platéia local. Suas comédias foram escritas em prosa e na língua vernácula, e assim também o fizeram outros autores italianos que tomaram por base o modelo clássico, como Maquiavel - a sua Mandrágora, de 1513, é considerada a obra prima da comédia clássica italiana - e Bibbiena, com a Calândria, de 1518. A eles imitou Sá de Miranda, ambientando suas peças fora de Portugal - na Itália, como a indicar seu paradigma -, e também compondo em prosa e na língua materna, embora carregando pouco menos na acidez da crítica.

Sabe-se que em Portugal houve representações de comédias latinas, em latim, no meio estudantil. Adrien Roig dá-nos notícia de um "alvará real, de 28 de Setembro de 1546", que "pedia aos professores de terceira e quarta regra de latinidade da Universidade e aos do Colégio de São Jerônimo, que cada um compusesse e representasse uma comédia todos os anos", ${ }^{37}$ mas nada informa sobre estas composições. Pela data do alvará infere-se que essa influência no modelo educacional português foi tardia - Sá de Miranda havia feito representar sua primeira comédia regular quase vinte anos antes.

Bem se vê que o teatro latino não tinha entre os portugueses o mesmo destaque que Ihe davam os italianos. O teatro apreciado no Portugal de Quinhentos era, e continuaria a ser, o de Gil Vicente, que soube tirar proveito tanto dos

\footnotetext{
${ }^{36}$ Já se desenvolvia na Itália, desde o começo do século XV, um teatro humanista, escrito em latim, que fazia uso de topoi do teatro clássico de Plauto e Terêncio, mas não era regular.

${ }^{37}$ O teatro clássico em Portugal no século XVI. Lisboa: Instituto de Cultura e Língua Portuguesa Ministério da educação, 1983, p. 16. (Biblioteca Breve, v. 76). O estudo de Roig é um tanto falho e ufanista, mas traz algumas informações sobre datas de edições e traduções de comédias latinas em Portugal, sobre as comédias de Jorge Ferreira de Vasconcelos e sobre o cenário adotado nas representações italianas, que não foram encontradas em outros estudos. Deve-se lê-lo com certa cautela.
} 
elementos mais espetaculares das manifestações teatrais primitivas que atravessaram a Idade Média na Europa - os Mistérios, os momos, as mascaradas, as manifestações profanas das celebrações religiosas, que não parecem distanciarse muito das origens rituais do teatro - como da cultura humanística espanhola, na construção de um teatro bastante popular. Suas peças satirizavam a sociedade portuguesa, seus membros e instituições, naquele momento português de riqueza gerada pelos descobrimentos. Embora tratasse de temas tão sérios e fosse feito e representado para a corte, na corte, era um teatro popular e alegre, que reunia muitos efeitos cênicos e em que o autor tinha grande liberdade de composição, sem se prender a convenções e regras, como as do teatro antigo.

$\mathrm{Na}$ historiografia do teatro português, a comédia clássica consta mais pelo fato de marcar o início de um movimento literário, o Classicismo, do que por sua importância como gênero. Sá de Miranda, embora tenha sido não só o introdutor da comédia clássica mas do Classicismo em Portugal, como autor teatral mereceu parcos estudos por parte de seus próprios conterrâneos ${ }^{38}$ e sua contribuição para o teatro tem sido muitas vezes avaliada com menos mérito do que a de outros autores seus contemporâneos, como o próprio Gil Vicente - que por seus autos e farsas passou à história como tendo "inventado" o teatro português - e António Ferreira, cuja tragédia Castro Ihe rendeu o título de "inventor" da tragédia nacional (por esse raciocínio, Sá de Miranda deveria ser considerado o "inventor" da comédia erudita portuguesa, mas, como essa não despertou grande interesse, no que concerne ao teatro ele não "inventou" coisa nenhuma).

Autor de duas comédias regulares, Os Estrangeiros e Os Vilhalpandos, Sá de Miranda destacou-se na literatura portuguesa não por seu teatro mas por sua poesia lírica, que compôs tanto na "medida nova", por ele importada da Itália, como na "medida velha", da tradição medieval, deixando o título de doutrinador do movimento para o discípulo António Ferreira, poeta que aderiu totalmente ao Classicismo, rejeitando de todo a herança medieval e o bilingüismo cultivado pela literatura portuguesa da época e que acabou por superar o mestre em fama e talento dramático.

\footnotetext{
${ }^{38}$ Atualmente, Thomas Earle, da Universidade de Oxford, tem dedicado muitos trabalhos à obra teatral de Sá de Miranda.
} 
Além da tragédia Castro, que obteve grande êxito e tem sido sempre objeto de trabalhos acadêmicos, António Ferreira escreveu duas comédias seguindo as regras clássicas e o exemplo do mestre, a de Bristo e a do Cioso. Ao contrário da tragédia, suas comédias, do mesmo modo que as de Sá de Miranda, têm inspirado muito pouco os pesquisadores e recebido parcos estudos.

Outros autores que se aventuraram pela trilha clássica e merecem menção são Jorge Ferreira de Vasconcelos e Luís de Camões. O primeiro escreveu a Eufrosina (1555?), comédia com cenas imensas, longos monólogos e falas repletas de provérbios e citações, que teve como modelo principalmente $A$ Celestina, tragicomédia de Fernando de Rojas. ${ }^{39}$ "Comedia lhe chama o seu auctor [...], mas ella é na verdade uma novella dialogada, para ser lida, pacientemente, saboreandose na analyse e na meditação as suas longas divagações moraes." Assim define Fidelino de Figueiredo ${ }^{40}$ essa primeira peça de Ferreira de Vasconcelos, que foi seguida de Aulegrafia (1555) e Ulissipo (1569?), peças em que o autor não observa a unidade de ação, uma das regras do teatro antigo. "As três comedias de Jorge Ferreira têm um valor exclusivamente documental sobre os costumes sociaes, sobre a lingua e sobre o gosto da sua epoca, portanto valor historico e muito limitadamente esthetico", conclui Figueiredo. ${ }^{41}$

O teatro de Camões resume-se a três peças. São elas três autos nos quais o autor explora de alguma forma a cultura clássica da época: Auto dos Enfatriões, Auto do Filodemo e El Rey Seleuco. Segundo Marques Braga, o poeta "traduziu e parafraseou DUZENTOS VERSOS do Amphitryon do célebre poeta cómico latino"42 no seu Auto dos Enfatriões - informação que não se confirma pela nossa verificação: encontramos no auto camoniano 93 versos do Anfitrião de Plauto,

\footnotetext{
${ }^{39}$ Cf. BRAGA, Teófilo. História da Literatura Portuguesa II - Renascença. Sintra: Europa-América, [s.d.], p. 227. O autor afirma ser a Eufrosina anterior às comédias de Sá de Miranda "por que em uma cena se lê uma carta datada de Goa de 28 de Dezembro de 1526," (p. 226) tese derrubada por estudos posteriores, mas importa a informação que se segue: "Jorge Ferreira partia da forma medieval da Moralidade, vivificando-a pelo interesse das situações. Castigando o vício pela sua representação exagerada, tomava por modelo fundamental do gênero a Celestina." Tal informação se confirma na leitura de ambas as peças.

${ }^{40}$ Historia da Litteratura Classica - $1^{a}$ Epocha: 1502 - 1580. Lisboa: Livraria Clássica Editora de A. M. Teixeira \& Cia, 1922, p. 148.

${ }^{41}$ Ibidem, p. 152.

${ }^{42} \mathrm{Na}$ introdução aos Autos. Lisboa: Imprensa Nacional, 1928, p. 7. O célebre poeta latino a que se refere é Plauto.
} 
literalmente traduzidos ou parafraseados. O tema de El Rey Seleuco, Camões foi buscá-lo junto à literatura grega, no caso de amor de Antíoco pela mulher de seu pai, o rei Seleuco, narrado anteriormente por Plutarco, Valério Máximo, Apiano e retomado por Petraca nos Triunfos. E no Auto do Filodemo, o poeta mostrou destreza na prática da arte alusiva, se confirmada a informação que nos dá Marques Braga: "Consagra-se nesta obra dramática a genial tragicomédia castelhana La Celestina, alude-se ao petrarquismo, a Juan Boscan, a Garcilaso de la Vega e estampam-se versos [....] dos Romances de Bernardo del Carpio e del Cautivo."43 $\mathrm{O}$ autor d'Os Lusiadas manteve, porém, a tradição lírica nos autos em versos redondilhos, além de combinar elementos do romance de cavalaria com os clássicos e vicentinos, privilegiando a tradição medieval.

Inspirado na Antigüidade Clássica, Sá de Miranda escreveu ainda uma tragédia em versos intitulada Cleópatra, da qual restam somente poucos versos. Não são conhecidas as datas de composição e de representação desta peça, nem se ela guarda alguma relação com a Cleopatre Captive, de Jodelle, que é de 1552.

Ainda no que se refere ao teatro clássico português, temos notícia de uma tragédia de Anrique Aires Vitória, de 1536, que teria sido a tradução de uma peça espanhola adaptada da Electra de Sófocles, denominada A Vingança de Agamenon, mas o texto desapareceu e também desta não se sabe local e data de representação.

O teatro clássico português, com exceção da tragédia Castro, não foi apreciado senão por intelectuais e não vingou na terra de Gil Vicente. A comédia diferentemente do que ocorreu na Itália, berço do Renascimento, onde a primeira peça de imitação surge e se torna a base para o teatro moderno - vagou por algum tempo paralelamente ao teatro popular, de modelo vicentino, mais ao gosto dos portugueses. Seria o código do humor estabelecido pelo português diferente daquele do italiano? Poderíamos aventar a hipótese de que a comédia escrita em prosa não mantinha os jogos lexicais, as aliterações e o ritmo que, em conjunto, provocavam o riso nas comédias plautinas. Porém, observamos que pelo menos os jogos lexicais foram mantidos. "Os jogos de palavras, assim como os chistes de reflexão, são

${ }^{43}$ Op. cit., p. 7. Não conferimos a veracidade dessa informação. 
fontes de prazer porque nos permitem dispensar a relação de sentido entre as palavras e as coisas," afirma Verena Alberti, ${ }^{44}$ mas quer nos parecer que somente esses jogos, sem o acompanhamento de outros artifícios que o verso poderia proporcionar, não produziam o efeito cômico desejado. ${ }^{45}$ Entretanto, se pensarmos na comédia italiana, modelo para os portugueses, temos que, a princípio, ela também foi escrita em prosa, obtendo um êxito que não se repetiu ao ser reescrita em versos. ${ }^{46}$

Carregada de críticas ao clero, talvez essa comédia não encontrasse ambiente propício para o seu desenvolvimento em Portugal, cerceada que fora a liberdade de expressão à época, não só por quem exercia o poder, mas pelo próprio povo que se prostrava servil diante da Igreja. Por outro lado, sabemos que Sá de Miranda teve o apoio dos príncipes portugueses, que muito apreciaram suas comédias e as fizeram representar e publicar. Mesmo assim, a comédia clássica portuguesa jamais ganhou terreno na disputa com o teatro vicentino e acabou por perecer antes que pudesse amadurecer.

Seja como for, o fato é que a comédia clássica é erudita, segue as regras das poéticas clássicas e modela-se nas comédias de Plauto e Terêncio - e, em Portugal, também nas dos italianos -, de várias delas reproduzindo temas e versos os mais diversos. Este é o próprio princípio da imitação no Classicismo, como havia sido para os antigos, o que implica, nas palavras de Massoud Moisés, na "aceitação de modelos preexistentes à elaboração da obra de arte, sejam eles os escritores grecolatinos, sejam os quinhentistas que lhes seguiram as pegadas. $\mathrm{E} o$ acatamento de moldes pressupunha, inclusive, o empréstimo de versos inteiros ou temas." ${ }^{27}$

A imitação, ou o jogo alusivo, pressupõe também que o leitor ou ouvinte seja capaz de reconhecer as alusões e de fazer a relação entre os textos evocados e o texto recriado, ou esse jogo não cria nenhum sentido para além do da própria fábula (e o enredo das comédias, diga-se de passagem, é por vezes muito lento e recheado de longos monólogos, o que torna a fábula pouco atraente).

\footnotetext{
${ }^{44}$ O riso e o risível na história do pensamento. Rio de Janeiro: Jorge Zahar, 2002, p. 19.

${ }^{45}$ Sobre como se obtém o riso na comédia, ver o Tractatus Coislinianus. In: JANKO, Richard. Aristotle on comedy: towards a reconstruction of Poetics II. Los Angeles: University of California Press, 1984.

${ }_{47}^{46}$ Ariosto reescreveu suas comédias em verso.

${ }^{47}$ A literatura portuguesa através dos textos. São Paulo: Cultrix, 1991, p. 72.
} 
Repleto de intertextos, de alusões que não produziriam prazer algum se não pudessem ser reconhecidas, o teatro clássico é dirigido a um público douto, portanto, restrito a poucos. Sem reconhecer os antecedentes por ele evocados, o espectador, acostumado com o riso fácil provocado pelas farsas vicentinas, deveria sentir-se frustrado e aborrecido. O prazer do reconhecimento, a que se referia Aristóteles na Poética, era algo para poucos no caso de textos assim construídos.

Para tratar do processo de construção desses textos e de como a evocação de textos precedentes pode gerar sentidos para o leitor capaz de ouvir e reconhecer as tantas vozes que ecoam numa obra de imitação, passamos ao próximo capítulo. 


\section{Ars imitandi}

\section{A apropriação intencional de textos}

A principal característica da literatura clássica - compreenda-se tanto a literatura da Antigüidade Clássica como a do Classicismo - é ter como princípio de criação poética a apropriação intencional de textos precedentes, sejam eles muito anteriores ou mesmo sincrônicos ao que os toma como matéria exemplar. "Por princípio, um poeta jamais partirá do nada, mas criará sempre a partir de outros textos modelares," ${ }^{48}$ assevera Vasconcellos.

O autor que compõe sob esse princípio faz reconhecer seus predecessores e a tradição à qual se filia, empregando fórmulas e convenções que caracterizam o gênero da obra e tomando por empréstimo versos, ou partes de versos (textos ou parte de textos), temas e conteúdos conhecidos de um público determinado, que serão reproduzidos em um novo arranjo e em um novo contexto, num processo de recriação literária a que os romanos antigos denominaram imitatio.

Falamos, portanto, da imitatio como processo de criação de uma literatura "em segundo grau", da relação mimética que se estabelece entre uma obra literária e outra(s) obra(s) literária(s), ${ }^{49}$ relação que foi fundamental para o desenvolvimento de uma rica literatura na antiga Roma e que, por diferentes razões, torna a se impor como processo de criação poética entre os autores do Renascimento. ${ }^{50}$

\footnotetext{
${ }^{48}$ VASCONCELLOS, Paulo Sérgio. Efeitos intertextuais na Eneida de Virgílio. São Paulo: Humanitas, 2002, p. 23-24.

${ }^{49} \mathrm{O}$ termo correspondente a imitatio em grego, mímesis, designa, a princípio, outro tipo de relação: a que se estabelece entre as artes, em geral, e o mundo.

${ }^{50}$ No Renascimento, as causas que levaram à elaboração de uma literatura baseada na dos antigos são diferentes das que promoveram a literatura latina. A história é outra, o momento é de trazer de volta o homem para o centro das preocupações do próprio homem, destronando Deus do seu posto centralizador de todas as atenções. O homem, a natureza humana, que é o tema clássico por excelência, por suas qualidades de eterno e universal, sobrepõe-se aos temas sacros, religiosos, que determinaram as artes ao longo da Idade Média, voltando novamente a ser o tema central também
} 
No caso da literatura latina, houve uma causa histórica para que ela se estabelecesse por esse meio, que não foi unicamente "sua dependência inicial da literatura grega", considerada paradigma de excelência, como explica Vasconcellos:

Roma estreita seu contato com esta última no período helenístico, em que se praticava a atividade literária com amplo recurso às alusões intertextuais; de fato, sobretudo na poesia, desenvolve-se então a arte da intertextualidade, que se torna parte integrante do fazer literário. ${ }^{51}$

Temos, assim, que os poetas latinos tomaram de empréstimo à cultura grega não somente suas formas e conteúdos, textos ou partes de textos, mas também um modo de compor que já os poetas helenísticos praticavam, aludindo a outros textos, aperfeiçoando-o até a sofisticação alcançada por poetas como Virgílio e Horácio.

Claro está que aqui se trata de uma literatura produzida dentro de uma cultura escrita, que se baseia no culto, no estudo e no conhecimento profundo de textos escritos que são tomados como exemplo e que, para chegar ao nível de sofisticação a que chegou, desenvolve uma técnica de reelaboração criativa dos textos exemplares, uma técnica poética - nisso implicando o emprego de métodos de composição e de artifícios que promovam o jogo intertextual - a que chamamos, dando título a este capítulo, ars imitandi, mas que podemos perfeitamente denominar, na expressão de Pasquali, "arte alusiva”, posto ser a alusão o meio pelo qual o poeta evoca o texto precedente, além de ser matéria e instrumento a serviço do poeta - doctus imitator - na construção do texto novo.

Antes, porém, de buscarmos desvendar os segredos daqueles doutos poetas e de sua elaborada poética, gostaríamos de lembrar, citando Edmunds, "que havia poesia antes de livros de qualquer espécie e mesmo antes da escrita - poesia antes de textos." 52 Pensemos em Homero e na transmissão oral de seus poemas pelos aedos, geração após geração, o que permitiu que permanecessem vivos na memória coletiva desde o século VIII a.C., quando foram compostos, até o VI a.C.,

das artes, como havia sido na Antigüidade. Sobre a Razão como guia do homem renascentista na busca da Verdade, do Bem e do Belo universais, ver SPINA, Segismundo. Introdução à Poética Clássica. São Paulo: F.T.D., 1967.

${ }^{51}$ Op. cit., p. 23.

${ }^{52}$ EDMUNDS, Lowell. Intertextuality and the reading of Roman poetry. Baltimore: Johns Hopkings University Press, 2001, p. viii. 
quando foram fixados pela escrita. Pois Edmunds nos chama a atenção para a existência de um hexâmetro inscrito num jarro grego, o chamado Dipylon Oinochoe, de cerca de 740-730 a.C. (segundo o autor, é "a mais primitiva inscrição grega de mais de poucas letras"), em que se observa que tanto a linguagem quanto a versificação são homéricas. ${ }^{53}$

Mesmo se alguém assegurar que a escrita não era usada para composição em inscrições, mas somente para registrar uma fala que deveria ser lida em voz alta[...], permanece o fato de que a linha citada aqui é um texto escrito e esta escrita pressupõe e depende de uma composição antecedente, à qual me referi como sendo "homérica". Se, contudo, a épica homérica era conhecida do compositor da inscrição [...] somente a partir de performances, se o primeiro texto escrito de Homero tem data posterior à da inscrição, qual é a base em Homero da imitação do compositor? ${ }^{54}$

A explicação está no fato de que a fixação da poesia, do estilo poético de Homero, se deu antes de sua fixação pela escrita, antes do "texto". É o que nos mostra o exemplo de Edmunds, que a "intertextualidade" antecede o texto, pelo menos o texto escrito de que vínhamos tratando parágrafos acima, para o qual se elaboraram regras, métodos e princípios de composição. A poesia de Homero está no início de uma tradição que começa a se perpetuar independentemente da escrita. Evocar uma tradição é princípio da imitatio. E a própria imitatio era já uma tradição antes de se tornar a arte que ora investigamos - observe-se que não nos referimos à imitatio, ou mímesis, no mundo grego, entendida como a relação da obra de arte com o mundo, mas à que relaciona uma obra de arte com outra obra de arte, no caso da literatura, um texto com outro texto.

Recorremos a essa digressão para fazer lembrar que a intertextualidade, objeto de tantos estudos na atualidade, é tão antiga quanto a poesia e que, nesse sentido, a própria noção de texto pode se confundir com a de poesia. É lembrar que a poesia já era poesia, "composição", antes de ser "literatura", que Homero compunha seus poemas baseado "em copioso material preexistente, isto é, em poemas de proporções menores, em sagas, lendas, mitos de origem variada, que

\footnotetext{
${ }^{53}$ Op. cit., p. 5.

54 Ibidem., p. 5-6.
} 
iam sendo incorporados a conjuntos cada vez mais complexos. ${ }^{25}$ Tinha já, pois, predecessores de uma tradição oral com quem praticava o jogo alusivo.

Mas, desde que o jogo intertextual que a imitatio promove passa a ser concebido como fundamento do processo da criação poética, toda uma literatura começa a ser construída com base na apropriação intencional de textos e o jogo se transforma numa arte que regula e estabelece critérios para a composição literária e, mais que isso, que permite ao escritor imprimir sutilezas em seu fazer literário.

A realização dessa literatura implica, antes de tudo, na "aceitação [...] da imitação como um elemento essencial em toda composição literária" ${ }^{26}$, mas essa aceitação não implica em que a obra resulte numa cópia servil do modelo, nem exige que o poeta se torne escravo do predecessor, ou a sua será uma imitação "mal sucedida”. Nas palavras de Russell, "o poeta não pode deixar de ser imitator, esta é sua condição inevitável", mas ele pode evitar "a adesão meticulosa a aspectos verbais e superficiais de seu modelo." ${ }^{" 57}$ A imitatio propõe ao poeta aprofundar-se no universo de significações do texto imitado, permitindo-lhe aperfeiçoar e até corrigir possíveis falhas do modelo, incorporando, assim, o conceito de aemulatio - tentativa não só de igualar, mas de superar o modelo.

São, pois, imitatio e aemulatio, como seus correspondentes gregos mímesis e zēlōsis, conceitos que não se excluem, fazendo ambos parte do mesmo processo; "eles se complementam, quiçá como ars e ingenium na avaliação de Horácio sobre sua função em poesia", explica Russell. ${ }^{58}$

Os dois sempre se complementam; o processo que eles denotam pode ser bem ou mal feito, e a diferença reside não em mais ou menos mimēsis ou mais ou menos zēlōsis, mas na escolha do objeto, na profundidade do entendimento e no poder do escritor de tomar posse do pensamento para si mesmo. ${ }^{59}$

\footnotetext{
${ }^{55}$ NUNES, Carlos Alberto. A questão homérica. Na introdução de sua tradução de HOMERO, llíada. Rio de Janeiro: Ediouro, 2001, p. 10.

${ }^{56}$ RUSSELL, D. A. De imitatione. In: WEST, David \& WOODMAN, Tony (editors). Creative imitation and Latin Literature. Cambridge: Cambridge University Press, 1979, p. 1.

${ }^{57}$ Ibidem.

${ }^{58} \mathrm{Ibidem}$, p. 10. Russell não inclui nesse estudo, e não deixa claro se de modo proposital, o caso da inversão de sentido promovida pela paródia, que não supõe a intenção do poeta de igualar ou superar o modelo.

59 Ibidem.
} 
Para estabelecer critérios que definam como esse processo pode ser "bem feito", ou como a imitatio pode ser "bem sucedida", Russell, baseando-se em Longino, aponta cinco princípios - já revistos e comentados no trabalho de Vasconcellos, de quem nos valemos da tradução: ${ }^{60}$

1. "O objeto deve ser digno de imitação".

2. "Deve-se reproduzir o espírito mais que a letra".

3. "A imitação deve ser tacitamente reconhecida, na compreensão de que o leitor informado reconhecerá e aprovará o empréstimo".

4. "O empréstimo deve se tornar algo próprio, pelo tratamento individual e assimilação a seu novo contexto e propósito".

5. "O imitador deve pensar de si mesmo que está competindo com seu modelo, ainda que saiba que não é capaz de superá-lo".

O próprio Russell admite serem estes critérios vagos, gerais e evidentes, não explicitando exatamente o que era "a prática dos poetas", mas também sugere que não devem ser desprezados. São, afinal, pistas para o começo da análise literária e sugestões para quem deseja fazer um julgamento crítico desse tipo de texto.

Vasconcellos apõe observações a cada um desses princípios, que merecem ser mencionadas, pois esclarecem alguns pontos por demais vagos.

Quanto ao primeiro princípio, se há dúvida do que seja um "objeto digno de imitação", diz que se trata, "na maioria das vezes, de uma homenagem ao precursor, ainda quando as intenções do poeta são emulativas"61 e esclarece, em nota de rodapé, que não é sempre, "pois se pode, por exemplo, parodiar um mau verso citando-o de alguma forma." Assim, "na maioria das vezes", e não sempre,

\footnotetext{
${ }^{60}$ Op. cit., p. 36-39, e RUSSELL, op. cit., p. 16.

${ }^{61}$ Ibidem, p. 36.
} 
... o poeta venera seus modelos, inserindo-se numa tradição da qual não poderia prescindir. Sua obra incorpora a dos precursores que o poeta estima como paradigma de excelência, cuja "imitação" confere, por si só, a dignidade da auctoritas dos patres. ${ }^{62}$

Quanto ao segundo princípio, Vasconcellos julga ser esta a afirmação mais discutível das arroladas por Russell, por ser o jogo alusivo mais sutil e compreender ainda "o confronto estilístico com o modelo". 63

O terceiro princípio é mais claro. A alusão não pode passar despercebida ao leitor. A significação da alusão se completa no reconhecimento que dela faz o leitor, como veremos, mais adiante, neste capítulo.

Também o quarto princípio é claro, mas parece melhor explicado através das palavras de Vasconcellos:

... a operação intertextual jamais pode ser neutra, isto é, sempre cria novos sentidos que se sobrepõem ou contrastam com o do original reproduzido ou evocado. As formas de tratamento do material "tomado emprestado" são múltiplas [...] e nem sequer podem ser catalogadas de modo esquemático em sua totalidade, pois as possibilidades do jogo intertextual são virtualmente ilimitadas. ${ }^{64}$

Aemulatio é o conceito evocado no quinto princípio proposto por Russell e traz o sentido de competição: imitar para rivalizar com o modelo, buscando superálo. Como advertimos anteriormente, a aemulatio é parte do processo denominado imitatio. Não há aemulatio sem imitatio. Contudo, a imitação não pressupõe a emulação. Um autor pode aludir a um texto para parodiá-lo, como observou Vasconcellos sobre o primeiro princípio. Assim, "nem sempre a intenção é rivalizar com o modelo (corrijamos, pois Russell), mas, por vezes, simplesmente provocar o riso", 65 o que observamos muitas vezes nas comédias, especialmente na fala dos escravos, quando evocam um verso trágico, geralmente exagerando na expressão, em meio ao contexto cômico. ${ }^{66}$

\footnotetext{
${ }^{62}$ VASCONCELLOS, op. cit., p. 37.

63 Ibidem.

64 Ibidem, p. 38.

65 Ibidem, p. 40.

${ }^{66} \mathrm{O}$ conceito de aemulatio compreende, além da idéia de superação do modelo, a idéia de homenagem àquele que o poeta admira e, por isso, busca imitar e emular. Já a paródia nem sempre tem em vista a destruição do modelo, mas sim, com a descontextualização, provocar o riso. É o que
} 
Resumindo os princípios listados por Russell, juntamente com as observações de Vasconcellos, como os compreendemos, a imitatio bem sucedida é aquela em que a retomada de um texto anterior por um autor, envolvendo ou não aemulatio, e o reconhecimento dessa retomada caminhem juntos. Apropriar-se é tornar algo próprio e sem o reconhecimento não há apropriação. É através da alusão que um autor busca apropriar-se do outro. A alusão faz referência a um texto e/ou contexto que se supõe presente no universo referencial do leitor e o jogo alusivo deve imprimir novos sentidos ao texto retomado dentro do contexto novo, sem que se perca o sentido anterior, pois é no jogo de sentidos que a alusão promove que reside o prazer da leitura intertextual. Assim, o leitor deve reconhecer o sentido anterior e perceber o novo, encerrando o processo de apropriação e, por conseguinte, o de imitação.

A título de exemplo da imitação bem sucedida, citaremos um único verso de Virgílio comparado a seu modelo, verso que já inspirou diversas interpretações e, entre os autores que pesquisamos, é mencionado por Russell, Vasconcellos e Conte. O modelo é o verso 39 do poema 66 de Catulo; a apropriação é o verso 460 do livro VI da Eneida, ambos acompanhados da tradução de Vasconcellos:

Catulo: Inuita, o regina, tuo de vertice cessi.

"Foi contra a vontade, ó rainha, que saí de tua cabeça".

Virgílio: $\quad$ inuitus, regina, tuo de litore cessi.

"Foi contra a vontade, rainha, que saí de teu litoral". 67

A elegia de Catulo é tradução da de Calímaco "A Trança de Berenice". Nela, Catulo faz falar a própria trança, a relembrar à dona o momento em que fora cortada e depositada num templo para cumprir a promessa feita pela volta de seu marido ileso da guerra. ${ }^{68}$

se vê no Satiricon de Petrônio, como lembra Vasconcellos (op. cit., p. 40), ou na Apocoloquintose de Sêneca.

${ }^{67}$ Op. cit., p. 86.

${ }^{68}$ Cf. OLIVA NETO, João Ângelo. Nas notas aos poemas, por ele traduzidos. In: CATULO. O Livro de Catulo. São Paulo: Edusp, 1996, p. 228. 
Em Virgílio, quem fala é Enéias, dirigindo-se à sombra de Dido nos Infernos. Contextos absolutamente díspares e, no entanto, Virgílio integra o verso perfeitamente em seu poema, fazendo uso de uma das mais simples formas de alusão: a citação com modificações mínimas, que poderia ser tomada até mesmo como "adorno". "A semelhança quase total [...] induz ao confronto; trata-se, porém, de alusão difícil de interpretar," diz Vasconcellos, que cita as interpretações de vários outros estudiosos. Em sua própria interpretação, na Eneida,

... tudo o que diz respeito à história de amor entre Dido e Enéias é filtrado pelo código elegíaco (e trágico), desse modo incorporado ao épico; a reminiscência catuliana, em passagem que encerrará o episódio das relações entre os amantes, selando o fim definitivo de uma paixão que obstaculizava o cumprimento dos destinos, faz comparecer, num vislumbre, a atmosfera elegíaca que tinha dominado o livro IV, repleto de expressões do código da poesia elegíaca. Sua inserção num contexto diverso, em que adquire novo sentido, é belo índice da mudança de estatuto do herói Enéias: Dido permanece sempre a "ferida" por amor, [...] mas Enéias superou-se, e, ao invés de sucumbir ao mero papel de amante elegíaco, [...] transcendeu sua subjetividade, assumindo objetivamente a tarefa de tornar-se veículo do divino, executor piedoso, ainda que sofrido, dos destinos. O código elegíaco é integrado na estrutura da epopéia e ultrapassado pelo código épico; está presente com toda a força poética que Ihe conferiu Virgílio, mas submetido à visão de mundo da ação heróica, unificadora ideológica da obra. ${ }^{69}$

Russell e Conte dão também interpretações interessantes a essa retomada de Virgílio do verso catuliano, mas, para não nos alongarmos mais, julgamos ser a de Vasconcellos suficiente para fazer entender a função de uma retomada, de uma alusão, que, bem sucedida, pode produzir os mais diversos efeitos de sentidos, transformando o texto retomado em novo e próprio.

$\mathrm{Na}$ literatura do Renascimento, o processo será o mesmo: a imitatio; e a técnica será basicamente a mesma empregada pelos antigos, baseada na evocação num texto novo de textos precedentes, tendo a alusão como elemento de primeira necessidade para sua composição.

${ }^{69}$ Op. cit., p. 88. 


\section{2. "A alusão necessária"70}

A esta altura do trabalho, urge definir o termo "alusão" e outros a ele relacionados. O sentido de alusão confunde-se freqüentemente com os de evocação e referência, mas principalmente com o da própria imitação.

Para tentar esclarecer esse quadro confuso, apresentaremos, de forma resumida, os conceitos com que trabalham alguns dos mais importantes estudiosos de obras concebidas como literatura "em segundo grau". Comecemos pelas definições de Giorgio Pasquali, a quem a maioria dos autores que pesquisamos se volta no estudo dessa arte, à qual o filólogo italiano batizou de "arte alusiva" no tão breve quanto célebre artigo, assim intitulado, levado a público pela primeira vez em 1942. Neste artigo, Pasquali instituía, nas palavras de Bonanno, "um dinâmico jogo a três (autor, texto, leitor)," quem sabe, pressagiando os "futuros impulsos teóricos sempre em movimento." ${ }^{71}$

A relevância que Pasquali deu ao papel do leitor nesse jogo é de suma importância para a compreensão do conceito de alusão, como foi para sua formulação do conceito de "arte alusiva" em substituição ao de imitatio como arte, técnica de composição. ${ }^{72}$

Para Pasquali, "as imitações, o poeta pode desejar que escapem ao público", enquanto que "as alusões não produzem o efeito desejado senão sobre um leitor que se recorde claramente do texto ao qual se referem."73 Desse modo, entendemos que, para o filólogo italiano, as imitações - quer o autor cite literalmente ou prafraseie um texto anterior - incluem o plágio, se o poeta não deseja o seu reconhecimento pelo leitor; neste caso, o jogo intertextual, se assim o podemos chamar, não produz outra significação que não a superficial - o texto sob o texto não

\footnotetext{
${ }^{70}$ Aludimos aqui ao livro de BONANNO, Maria Grazia, L'allusione necessaria. Roma: Ateneo, 1990, cujo sugestivo título - e, naturalmente, sua instigante matéria - nos inspirou este tópico do trabalho. ${ }^{71}$ BONANNO, op. cit., p. 13.

${ }^{72}$ Vale lembrar que o trabalho de Pasquali, tanto quanto os de Conte, Bonanno, Russell, Edmunds, Cairns, entre outros, de que nos valemos para o desenvolvimento desta dissertação, dizem respeito à "poesia culta, douta", que é a que temos como objeto de pesquisa. A teoria bakhtiniana de dialogismo e ambivalência, que começa a ser divulgada por Kristeva em 1966, e o próprio trabalho de Kristeva, mais voltados para a análise do discurso e as ciências da linguagem, são de pouca valia para os estudos da intertextualidade na poesia clássica - pouca, mas não nenhuma, como se verá adiante. ${ }^{73}$ PASQUALI, Giorgio. "Arte Allusiva”. In: Stravaganze - Quarte e Supreme. Venezia: Neri Pozza, 1951, p. 11. Grifos nossos.
} 
transparece, ficando somente o próprio autor ciente de sua existência. Já a alusão pressupõe o reconhecimento e a compreensão por parte do leitor do texto e do contexto que ela evoca, e deixa de fazer sentido se o leitor não a percebe. Em ambos os casos, o leitor é predeterminado pelo autor: no primeiro, ele é um leitor que não conhece o texto imitado; no segundo, é o capaz de reconhecê-lo.

A arte alusiva é, assim, um jogo que se estabelece entre três partes: autor, texto(s) e leitor. Nesse jogo, em que "a alusão é o meio, a evocação o fim", ${ }^{74}$ a intertextualidade faz a seleção entre os leitores. ${ }^{75}$

Tomando essa posição, Pasquali deixa clara a sua intenção de colocar-se ao largo da Quellenforschung (investigação da fonte) e da idéia de que "a fonte da poesia está sempre e unicamente na alma do poeta" ${ }^{76}$ Foge, também, do que Edmunds chama, citando Hinds, de "fundamentalismo filológico"77: enxergar intenção do autor e reminiscências em tudo. "As reminiscências podem ser involuntárias", diz Paquali. ${ }^{78}$

Quanto à Quellenforschung, não há como negar o seu valor para os estudos da intertextualidade, mas havemos de lembrar que a análise intertextual não se encerra na descoberta da fonte. Como lembra Vasconcellos,

... é passo indispensável e primeiro para a análise intertextual, pois que de início, obviamente, é preciso detectar a alusão, tarefa árdua, que exige conhecimento extenso e ativo dos escritores da tradição cultural em que se insere o poeta ou prosador em foco, bem como a perspicácia de perceber sutilezas alusivas, mas não se pode dizer que se compreendeu a função de uma retomada de outro texto simplesmente quando se apontou a "fonte" ou "fontes" certas ou possíveis. ${ }^{79}$

Assim, se, para a filologia, "alusão é material que está objetivamente no texto", ${ }^{80}$ para o jogo a três que propõe Pasquali, alusão é algo subjetivo e os significados que ela pode gerar só se integram ao texto se o leitor for capaz de identiificá-los. As reminiscências, por outro lado, podem ser alusões que só existem

\footnotetext{
${ }^{74}$ PASQUALI, op. cit., p. 13.

${ }^{75}$ Ou, nos termos de Edmunds (op. cit., p. 165), "a intertextualidade discrimina um leitor de outro."

${ }^{76}$ BONANNO, op. cit., p. 11.

${ }_{77}$ Op. cit., p. xix.

${ }^{78}$ Op. cit., p.11.

${ }^{79}$ Op. cit., p. 25.

${ }^{80}$ EDMUNDS, op. cit., p. 43.
} 
da parte do leitor, provindas de seu universo de referências e não, efetivamente, do pensamento do autor. Combinadas com uma tendência a se buscar as fontes de tudo e a tudo imputar a intenção do autor, as reminiscências involuntárias podem resultar em má ou superinterpretação. Edmunds dá como exemplo de confusão causada por referências desse tipo a provocada por uma frase encontrada na obra de T. S. Eliot The Waste Land (1922), exemplo que aqui reproduzimos:

\begin{abstract}
John Newton identificou a fonte da frase "handful of dust" em The Waste Land como sendo um poema de Charlotte Mew (1916). Em questão de semanas, apareceram cinco desafiantes para Newton. Eles encontraram a fonte da frase diferentemente em Alfred, Lord Tennyson (duas vezes), John Donne, Joseph Conrad, e Walter de la Mare. Eles também compararam pulueris exigui iactu (Virg. G. 4, 87) e pulueris exigui ... parua munera (Hor. C. I, 28, 3-4). Todos estes são autores e obras que Eliot provavelmente leu. Se Eliot fosse vivo, seria capaz de nomear um destes como sua fonte? [...] Considerando que Eliot pode ter pretendido aludir a uma ou mais das fontes citadas, ainda assim sua intenção não pode ser averiguada, temos também que levar em conta o caso em que a intertextualidade não é pretendida de forma alguma mas é percebida pelo leitor - intertextualidade a despeito da intenção." 81
\end{abstract}

No caso de textos como os que analisamos, a alusão é necessária, é indispensável para que o autor faça com que seu texto evoque outro texto que deve ser reconhecido pelo leitor, apontando para a também necessária existência de um leitor-modelo, um leitor-intérprete, que é aquele culto, instruído na mesma tradição do autor - este o leitor capaz de tomar parte no jogo intertextual praticado na imitatio. Existe, porém, entre estes, aquele leitor a que Eco denomina "intérprete paranóico", 82 o que se questiona o tempo todo quanto aos "motivos misteriosos" que levam um autor a "aludir" a determinado texto, não considerando jamais a involuntariedade de uma "retomada". Neste caso, a intentio lectoris e não a intentio auctoris produz a evocação e a interpretação tomará o rumo que melhor servir aos propósitos interpretativos desse leitor. ${ }^{83}$

Paralelamente a esse tipo de leitura superinterpretativa, encontra-se aquela leitura influenciada por teorias como a divulgada por Kristeva, que supõem a

\footnotetext{
${ }^{81}$ Op. cit., p. 22.

${ }^{82}$ ECO, Umberto. Interpretação e Superinterpretação. São Paulo: Martins Fontes, 2005, p. 57.

${ }^{83} \mathrm{Ibidem}$. Essa idéia perpassa todo o livro.
} 
alienação do "sujeito da escritura" e não levam em conta a literatura que se constrói consciente e intencionalmente como "mosaico de citações". 84 É uma leitura que concebe o texto como um processo de entrelaçamento de idéias várias, que provêm tanto de outro(s) texto(s) como do meio social e da história do(s) sujeito(s) da escritura - o da atual e o(s) da(s) evocada(s) -, somadas às idéias que carrega o leitor atual, de forma que "a palavra (o texto) é um cruzamento de palavras (de textos) onde se lê pelo menos uma outra palavra (texto)." ${ }^{85}$ Para designar essas relações entre texto, sociedade e história - considerando as duas últimas também como "textos" -, Kristeva cunhou o termo intertextualidade. ${ }^{86}$ Desta perspectiva, todo texto é, por natureza, intertextual, independentemente da vontade do escritor.

Em contraposição à corrente revolucionária que instituiu a "morte do sujeito", encontramos Conte, apostando nas alusões como figurae elocutionis, na "função retórica da alusão como um aspecto do caráter sistemático da composição literária,"87 estando, assim, de alguma forma, sob o controle do escritor. Como as figuras, a alusão provoca "uma tensão entre o significado literal e o figurativo, entre o 'uerbum proprium' e o 'improprium'." ${ }^{88}$ A tensão entre as duas realidades contrapostas cria a dimensão poética do texto.

Conte compara a alusão à metáfora, por serem ambas 'formas 'impróprias' de expressão":

Ambas existem em virtude de sua "duplicidade" semântica, e seu valor literário reside em sua capacidade de encerrar em tensão, dentro delas mesmas, o espaço vazio que se estende entre seu valor lexical e a imagem que elas obliquamente evocam. ${ }^{89}$

A comparação é interessante, mas, como bem observa Edmunds, ${ }^{90}$ desconsidera o fato de que a metáfora pode ser percebida por qualquer leitor,

\footnotetext{
${ }^{84}$ A expressão utilizada e tornada pública por Kristeva no artigo "Le mot, le dialogue et le roman",

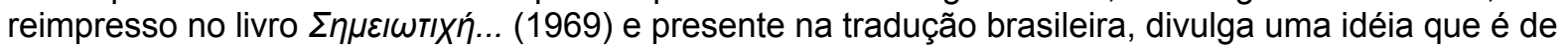
Bakhtin.

${ }^{85}$ KRISTEVA, Julia. Introdução à semanálise. 2. ed. São Paulo: Perspectiva, 2005, p. 68.

${ }^{86}$ Ver a interessante análise do trabalho de Kristeva que faz EDMUNDS, op. cit.

${ }^{87}$ CONTE, G. B. The Rhetoric of Imitation. Ithaca and London: Cornell University Press, 1996, p. 26.

${ }^{88}$ Ibidem, p. 24.

${ }^{89}$ Ibidem, p. 53.

${ }^{90}$ Op. cit., p. 166.
} 
enquanto a alusão é uma "figura" que só um leitor "instruído" pode reconhecer como tal. A leitura que Conte propõe privilegia o texto, a construção do texto, as relações entre textos que se dão de forma consciente e técnica, tendo em mente a tradição dentro da qual o texto surge, uma tradição que ele define como "língua poética", "a projeção simultânea de modelos e códigos literários, [...] um sistema de regras e prescrições." 91 Essa tradição, ou língua poética, prevê o que ele denomina memória poética, que é ativada pela alusão, e pressupõe que autor e leitor estejam familiarizados com seus modelos e códigos - ou com o "modelo-código".

Antes de a alusão poder ter o efeito desejado sobre o leitor, primeiro ela deve exercer aquele efeito sobre o poeta. Quanto mais facilmente o original puder ser reconhecido - quanto mais "citável" (porque memorável) ele é - mais intenso e imediato será o seu efeito. [...] Assim, a alusão ocorrerá como um ato literário se uma vibração concordante puder ser estabelecida entre as memórias do poeta e do leitor quando elas estiverem direcionadas para uma fonte já armazenada em ambos. [...] Uma única palavra no novo poema será muitas vezes suficiente para condensar uma inteira situação poética e reavivar o seu ânimo. ${ }^{92}$

Para Conte, despojado da carga ideológica, o termo intertextualidade pode equivaler à expressão "memória poética" “- uma equivalência funcional estratégica adequada às nossas necessidades", avisa. ${ }^{93}$

Da mesma forma Genette, desobrigando-se de implicações com o trabalho de Kristeva, usa o termo como paradigma para criar uma terminologia útil à análise de textos "em segundo grau", ${ }^{94}$ como se verá mais à frente. Para ambos, o termo imitação tem um sentido limitado, referindo-se à apropriação de um estilo, ou de um tipo específico de texto. Mas enquanto Conte - assim como Pasquali - liga "imitação" ao impulso de emular (lembrando que, para Conte, a "memória poética" não se reduz a esse impulso), Genette, cujo trabalho privilegia os processos de inversão de sentido, distingue dois tipos de obra imitativa: um em que o autor se

\footnotetext{
${ }^{91}$ CONTE, op. cit., p. 27.

92 Ibidem, p. 35.

${ }^{93}$ Ibidem, p. 29. É interessante lembrar que Michel Pêcheux, um dos maiores nomes da Análise do Discurso, estabelece a noção de interdiscurso, definindo-o como "memória discursiva", aquela que evoca ditos preexistentes que constituem o novo discurso (ver, além da própria obra de Pêcheux, os estudos de Eni Orlandi, entre outros, sobre o assunto). O que Conte define por memória poética poderia, assim, ser estabelecido como interpoesia.

${ }^{94}$ GENETTE, Gérard. Palimpsestes - la litttérature au second degré. Paris: Seuil, 1982.
} 
apropria do texto e outro em que ele se apropria do estilo. Ao primeiro tipo denomina "transformação", ao segundo, "imitação". A transformação lúdica resulta na paródia, a satírica, no disfarce, e a séria, na transposição do texto. A imitação lúdica resulta no pastiche, a satírica, na caricatura, e a séria, no forjamento de um estilo. ${ }^{95}$

Genette distingue ainda alusão, citação e plágio, entendendo cada qual como uma forma diferente de relação intertextual. De seu ponto de vista, a citação é a forma de relação intertextual mais explícita e mais literal, "com aspas, com ou sem referência precisa"; o plágio é "uma forma menos explícita e menos canônica, [...] é um empréstimo não declarado, mas ainda literal"; e a alusão é "uma forma ainda menos explícita e menos literal [...], um enunciado cuja plena compreensão supõe a percepção de uma conexão entre ele e um outro ao qual remete". ${ }^{96}$

No que diz respeito à alusão, o quadro, que a princípio nos propusemos a esclarecer, parece ter-se tornado ainda mais nebuloso; quanto ao conceito de imitação, não menos obscuro. Mas, antes de concluirmos qualquer coisa a esse respeito, consideremos ainda o que diz Bakhtin, nos termos de Kristeva, sobre a utilização por um autor da "palavra de outrem". Apenas para contextualizar, Bakhtin, segundo Kristeva, ao tratar da classificação das palavras na narrativa, distingue três categorias de palavras: a primeira é a palavra direta, que é a palavra denotativa, a do autor; a segunda, a palavra objetal, que é o discurso direto das personagens.

Mas o autor pode se servir da palavra de outrem para nela inserir um sentido novo, conservando sempre o sentido que a palavra já possuía. Resulta daí que a palavra adquire duas significações, que ela se torna ambivalente. Essa palavra ambivalente é, pois, o resultado da junção de dois sistemas de signos. [...] A junção de dois sistemas de signos relativiza o texto. É o efeito da estilização que estabelece uma distância relativamente à palavra de outrem, contrariamente à imitação (onde Bakhtin tem em vista, sobretudo a repetição), que toma o imitado (o repetido) a sério, torna-o seu, apropria-se dele, sem o relativizar. Essa categoria de palavras ambivalentes caracterizase pelo fato de que o autor explora a palavra de outrem, sem ferir-lhe o pensamento, para suas próprias metas; segue sua direção deixando-a sempre relativa. Nada disso ocorre na segunda categoria das palavras

\footnotetext{
${ }^{95} \mathrm{O}$ quadro geral dessas práticas, que o autor denomina hipertextuais, encontra-se à $\mathrm{p}$. 37. Usamos a tradução dos termos feita por Possebon, em seu estudo sobre HOMERO, Batracomiomaquia. São Paulo: Humanitas, 2003, p. 73.

${ }^{96}$ Op. cit., p. 8.
} 
ambivalentes, da qual a paródia é um tipo. Aqui o autor introduz uma significação oposta à da palavra de outrem. ${ }^{97}$

A alusão pertence justamente a essa categoria de palavras ambivalentes, que carregam dois, ou mais, sentidos, o novo e o que já possuíam no(s) texto(s) e contexto(s) anteriores - um autor pode aludir a um texto que já aludia a outro anterior. Tem, assim, uma função semelhante à da figura, como propõe Conte. E, como figura do discurso poético, a alusão serve à construção da obra literária em seus vários gêneros e nas várias formas em que a imitação (como a entendemos) pode se processar: a estilização, a paráfrase e a paródia, processos em que, numa definição bastante simples, podemos dizer, com Sant'Anna, "a paródia deforma, a paráfrase conforma e a estilização reforma." 98 Dizemos bastante simples - de forma nenhuma desmerecendo o trabalho deste autor - porque o processo de imitação é bem mais complexo, quanto mais o que envolve a construção do texto como montagem de fragmentos, em que cada fragmento pode indiferentemente estilizar, parafrasear ou parodiar o fragmento que evoca e, ainda assim, ser o texto no seu todo - na sua arquitextualidade - uma paródia, uma paráfrase ou uma estilização. Note-se que Bakhtin (por Kristeva) dá ao termo imitação o sentido que a paráfrase apresenta em Sant'Anna: "a paráfrase, repousando sobre o idêntico e o semelhante, pouco faz evoluir a linguagem", 99 ou seja, é repetição. E a estilização se aproxima da emulação, que relativiza mas não fere o sentido da texto anterior: "na estilização não ocorre uma 'traição' à organização ideológica do sistema como ocorreria na paródia, onde há uma perversão do sentido original."100 Mas, havemos de lembrar que nenhum desses processos é neutro. Repetindo o que já citamos de Vasconcellos, "a operação intertextual [...] sempre cria novos sentidos que se sobrepõem ou contrastam com o original reproduzido ou evocado", e tantas são as formas de se tratar o "material 'tomado emprestado"” que "nem sequer podem ser catalogadas de

\footnotetext{
${ }^{97}$ KRISTEVA, op. cit., p. 76-77. Os itálicos são da autora, os negritos, nossos. Estranhamente, Bakhtin (por Kristeva) diz ser o romance "o único gênero que possui palavras ambivalentes", quando sabemos que, em poesia douta, a alusão, que se caracteriza pela ambivalência, toma parte na composição de todos os gêneros poéticos.

${ }_{98}$ SANT'ANNA, Affonso Romano de. Paródia, paráfrase \& Cia. 7. ed. São Paulo: Ática, 2001, p. 41.

${ }^{99}$ Ibidem, p. 27-28.

100 Ibidem, p. 39.
} 
modo esquemático [...], pois as possibilidades do jogo intertextual são virtualmente ilimitadas." 101

Ao longo desta pesquisa, observamos que, entre os teóricos da "arte alusiva", ou da intertextualidade, que é um termo mais abrangente, citar um ao outro é a maneira de defender seus pontos de vista e redefinir conceitos conforme as necessidades de suas próprias teorias, resultando seus textos - como este que ora desenvolvemos - num "mosaico de citações" e num exemplo de operação intertextual. Assim, também nós, partindo dos vários pontos de vista observados - e citados - e sem criar nenhum termo novo, apresentaremos definições para os conceitos relativos a essa arte, conforme os entendemos e deles faremos uso em nossa análise.

Tomamos as obras que investigamos como produto de um contexto históricoliterário específico, de uma tradição literária autônoma, como propõe Conte, em que o imitar era a regra. O poeta tem como intenção primeira ao compor esse tipo de obra inserir-se numa tradição literária que não só aceita como pressupõe a alusão a textos precedentes, ou seja, uma tradição literária em que as relações intertextuais se dão de maneira consciente e técnica.

À técnica poética, cujo processo de apropriação intencional de textos alheios - não importando se a intenção do poeta é emular ou parodiar o modelo examinamos neste trabalho, chamamos ars imitandi - arte de imitar - ou "arte alusiva", indiscriminadamente. O processo será aqui denominado imitatio, considerando a aemulatio e a paródia como formas de imitação. Processo alusivo, por excelência, a imitatio promove a intertextualidade - a relação entre textos.

Apropriação é a ação de tomar um texto anterior (que pode ser do próprio autor), incorporá-lo a um texto novo e torná-lo próprio pelo novo sentido que ele adquire dentro do novo contexto em que se insere. A apropriação, em poesia culta, é sempre intencional, e é a alusão que dinamiza seu processo.

A alusão é o principal dos artifícios do imitador, doctus imitator, que, naturalmente, lança mão também de outros recursos na construção de sua obra. Nas comédias, por exemplo, os trocadilhos e jogos de palavra, em geral, são

${ }^{101}$ Op. cit., p. 38-39. 
bastante usados para atingir-se o cômico. Hipérbatos, anáforas, metáforas e um sem número de figuras podem enriquecer o texto, mas é a alusão, ao fazer a referência a outro texto, que ativa o jogo intertextual praticado em poesia douta. Parafraseando Pasquali, alusão é o meio pelo qual o poeta evoca outro texto e a evocação, a finalidade de se aludir - fazer lembrar, levando em conta que o leitor tem as mesmas referências que o autor, que ele é um doctus lector.

A alusão pode evocar por diversos meios e com diversos fins. ${ }^{102} \mathrm{O}$ meio mais comum e mais simples é a citação literal, não necessariamente entre aspas: reprodução (se em língua estrangeira, tradução) de versos inteiros ou trechos de versos. A citação pode também se apresentar com pequenas modificações - como no exemplo citado acima do verso de Virgílio - ou mais transformada, como paráfrase, dizendo o mesmo em outras palavras - lembrando que se pode confundir uma citação literal com paráfrase por conta das diferentes escolhas vocabulares dos tradutores; a paráfrase, em geral, como observamos nos diversos textos cômicos investigados, condensa falas (ou versos) do texto original, especialmente porque 0 modelo latino, que é originalmente composto em versos, é reproduzido em prosa pelos escritores renascentistas.

Outro meio pelo qual a alusão evoca outro(s) texto(s) é a "condensação"103 _ e agora o termo não diz respeito à paráfrase. Trata-se da fusão de duas metades de versos diferentes, numa "espécie de contaminatio em miniatura", ${ }^{104}$ evocando, ao mesmo tempo, dois textos ou contextos diferentes.

O poeta pode ser ainda mais sutil - e habilidoso - ao evocar todo um contexto através de uma única palavra. Essa é uma alusão de caráter muito mais complexo e que só é explícita a um leitor suficientemente atento.

A alusão pode, às vezes, ter a simples função de ornato, pela "beleza evocativa dos sons", ou ainda uma função meramente estrutural, ao evocar a

\footnotetext{
102 Orientamo-nos, aqui, por Vasconcellos, op. cit., Capítulo II.

103 Nome, segundo Vasconcellos, sugerido por Joseph Farrell, na obra, por ele citada, Vergil's Georgics and the Traditions of Ancient Epic. The Art of Allusion in Literary History.

${ }^{104}$ A contaminatio é uma técnica de criação literária que consiste em misturar dois ou mais textos modelares para obter um texto inédito. Utilizada, principalmente, pelos comediógrafos latinos, pode ser observada também em outros gêneros. No proêmio da Eneida, por exemplo, temos um exemplo de contaminatio - ver VASCONCELLOS, op. cit., p. 112-124. Trataremos desta técnica no capítulo seguinte deste trabalho.
} 
"situação" que se imita, "confrontando duas unidades narrativas semelhantes." Pode também servir à retomada de fórmulas - no caso das comédias, fórmulas do cômico - para situar a obra numa tradição literária, num "conjunto de textos que definem o gênero ao qual se filia", funcionando, assim, como "marca de gênero". E, como se pode notar nos textos do Classicismo, o poeta evoca também, com freqüência, a Antigüidade em geral, aludindo a acontecimentos reais ou fictícios, a personagens históricas ou da ficção, encontradas nos vários gêneros poéticos, como que afirmando sua inserção não só num gênero mas em todo um contexto clássico e erudito. Mas a principal função da alusão é provocar o "estranhamento", que é ocasionado pela colocação da citação, mais ou menos transformada, mais ou menos sutil, no novo contexto.

Segundo Vasconcellos, o poeta pode também, ao retomar modelos, "resgatálos desviando-se, porém, em certos aspectos estilísticos":

Trata-se do que poderíamos denominar "correção estética" do precursor, um dos pontos mais difíceis de detectar e interpretar no domínio intertextual [...]. Antes de mais nada, esse desvio do original não invalida o valor de homenagem da citação; o poeta venera os modelos que incorpora, ainda quando opera sobre eles a "retificação" estilística que the parece adequada. ${ }^{105}$

Pode ainda o poeta desejar que a alusão provoque o efeito de ironia. Em geral, a ironia resulta na paródia, que é, novamente nas palavras de Vasconcellos,

... uma das formas de intertextualidade mais fáceis de detectar. Por vezes, basta reproduzir tal e qual um verso célebre fora de seu contexto, transportando-o para contexto totalmente diverso, e se produz ironia, só percebida pelo leitor que tenha na memória a expressão reproduzida e, pela transposição, distorcida. ${ }^{106}$

É claro que o "estranhamento" - qualquer efeito que o poeta possa desejar provocar através da alusão - só ocorre havendo o reconhecimento, por parte do leitor, do contexto anterior. Senão, não há evocação e a alusão não cumpre sua função.

\footnotetext{
${ }^{105}$ VASCONCELLOS, op. cit., p. 161.

${ }^{106}$ Ibidem, p. 170.
} 
Que a alusão, nesses textos, é consciente, intencional e técnica, obedecendo ao propósito de imitar como princípio de criação poética, compreendemos como fato. Que a leitura desses textos deve levar em conta as relações intertextuais que neles se travam produzindo sentidos, é também incontestável - embora o leitor "não instruído" possa encontrar sentidos no texto que não os que provêm da percepção da intertextualidade - e, por assim ser, exige um leitor-modelo, que é aquele que tem o domínio do campo de referências em que o texto se constrói, podendo decodificá-las e interpretá-las. ${ }^{107} \mathrm{O}$ que permanece em questão é como interpretar essas relações, como detectar qual foi a intenção do poeta ao evocar determinado texto ou contexto, quando não é e nunca será dado ao leitor acessar a mente do poeta.

Bem lembra Edmunds que o intérprete "deve ser um leitor do poema; ele não pode ser um leitor da mente."108 $\mathrm{O}$ que o leitor tem à mão para iniciar o trabalho de interpretação é o "material que está objetivamente no texto". Alcançar os significados subjacentes implica em conhecimento profundo dos textos da tradição e na observação cautelosa de todo o contexto em que a alusão se insere e, ainda assim, toda interpretação será somente uma possibilidade. No caso da alusão de Virgílio, com que exemplificamos a imitação bem sucedida, há outras possibilidades de interpretação, embora a de Vasconcellos nos pareça perfeita. Russell, por exemplo, numa interpretação muito menos trabalhosa - e muito menos cautelosa - supõe que Virgílio quis mostrar como colocar em melhor uso um verso que Catulo desperdiçou. ${ }^{109}$

Outra coisa que devemos ter em mente ao entrar no jogo alusivo e tentar interpretar uma alusão é que uma eventual semelhança entre um texto e outro pode resultar de dois autores terem se voltado para um mesmo texto precedente, ou

\footnotetext{
${ }^{107}$ Lembramos que a poesia douta circulava num meio restrito - à roda de Augusto, na Roma antiga, nas cortes do Renascimento - e era, em geral, dedicada a um patrocinador ou a quem o poeta desejasse agradar com seu texto - a Augusto, a Mecenas; mais tarde, aos duques e príncipes. Estes exemplificam o leitor-modelo de então, sem contar que os textos gregos eram lidos na escola. Hoje, com os estudos e notas que acompanham as edições dos textos que chegaram até nós, qualquer leitor - não é preciso ser um filólogo - pode sentir o prazer da leitura intertextual.

${ }^{108}$ Op. cit., p. 20.

109 Op. cit., p. 13.
} 
ainda, nas palavras de Conte, "para um código literário comum" $" 110$ e não necessariamente um ao outro.

O jogo alusivo é praticado por diversos meios, como temos até aqui observado e buscado explicitar, mas a análise intertextual exige ainda uma terminologia que se desdobre e abarque todas as possibilidades do processo. Assim, quanto a essa terminologia, nos apoiaremos especialmente na proposta por Genette para definir os casos de "transtextualidade" 111 - a transcendência textual do texto. $O$ autor identifica cinco casos de relações transtextuais:

- Intertextualidade: cunhado por Kristeva, o termo tornou-se paradigma terminológico, e define-se, de maneira geral, "pela presença efetiva de um texto dentro de um outro."112 Segundo o autor, a relação intertextual se apresenta em três formas, já citadas e definidas acima, que são a citação, o plágio e a alusão.

- Paratextualidade: um texto pode promover a relação intertextual a partir de seu título, ou da capa do livro, ou de ilustrações, entre "outros tipos de sinais acessórios[...]."113 Bom exemplo de paratexto nos dá Vasconcellos, tratando da Eneida:

Já o título da epopéia de Virgílio estabelece com o leitor o pacto de intertextualidade que deverá reger a leitura da obra; diríamos, utilizando a nomenclatura de Genette, que a relação hipertextual da Eneida com o modelo homérico em especial é assinalada por Virgílio nesse componente do "paratexto" que é o título. De fato, Aeneis informa o leitor de que se terá como tema um herói de nome Enéias, como a Odisséia centra seu foco narrativo em Odisseu. ${ }^{114}$

\footnotetext{
${ }^{110}$ Op. cit., p. 28.

${ }^{111}$ Op. cit., p. 7.

112 Ibidem, p. 8.

113 Ibidem, p. 9.

114 Op. cit., p. 125.
} 
- Metatextualidade: comentário que um texto faz de outro, sem necessariamente citá-lo. Ocorre quando há uma relação crítica entre os textos. $^{115}$

- Hipertextualidade: "toda relação que une um texto B (... hipertexto) a um texto anterior A (... hipotexto) no qual ele se enxerta de uma maneira que não é a do comentário." ${ }^{116} \mathrm{Em}$ outras palavras, refere-se a um texto "em segundo grau" ou derivado de um outro texto preexistente. A Eneida, de Virgílio, e o Ulisses, de James Joyce, por exemplo, mantêm uma relação hipertextual com o hipotexto Odisséia, de Homero.

- Arquitextualidade: relação abstrata e implícita, muitas vezes não mais que uma menção paratextual de pertinência taxionômica - Poemas, Romance, Ensaios - ou indicações que acompanham o título do livro na capa, por exemplo. ${ }^{117}$ Tal relação diz respeito ainda aos tipos de discurso, modos de enunciação, gêneros literários a que o texto alude em suas fórmulas e convenções. $\mathrm{O}$ arquitexto quer inserir-se num gênero ou tradição literária.

Entre esses termos definidos por Genette, não empregaremos em nosso trabalho "transtextualidade", por considerarmos que o conceito excede as nossas necessidades. "Intertextualidade", que em sua definição é um dos tipos de transtextualidade, é um termo cuja conceituação é suficientemente abrangente para cobrir nossa área de pesquisa. Também o termo "metatextualidade" ficará de fora, visto que o tipo de relação intertextual que define, obviamente, não se dá nas obras que analisamos e aqui constou somente por estarmos listando todas as definições do autor. Todos os outros termos interessam a este trabalho e definirão as relações intertextuais verificadas em nossa análise.

Além das relações definidas por Genette, sob os termos expostos acima, é possível encontrar num hipertexto - que pode derivar de um ou de vários hipotextos

\footnotetext{
${ }^{115}$ Cf. GENETTE, op. cit., p. 10.

116 Ibidem, p. 11 e 12. Grifos nossos.

117 Ibidem, p. 11.
} 
- outras relações intertextuais. Para outros dois tipos de relação entre textos não definidos pelo estudioso francês, faremos uso dos termos empregados por Vasconcellos, em sua análise da Eneida:

- Intratextualidade: "concebida como evocação, no curso de uma obra, de passagens da mesma obra: alusão interna, portanto". ${ }^{118}$

- Autotextualidade: "consiste na autocitação, isto é, na evocação, em dada obra, de uma passagem de outra obra do mesmo autor". ${ }^{119}$

Verificamos essas relações, os meios e modos de imitação e as possibilidades do jogo alusivo até aqui apresentados na literatura latina e também na renascentista italiana, modelos para Sá de Miranda, e ora buscaremos desvendar como se deu o processo criativo da imitatio nas comédias portuguesas.

Em resumo, é preciso não esquecer que a finalidade do jogo alusivo é evocar sentidos e não simplesmente adornar um texto com citações de outro(s) texto(s). Por isso não basta num trabalho de análise intertextual detectar as fontes ou paradigmas literários, o que é, como já dissemos, só o primeiro passo, sem compreender o sentido que a alusão suscita. Na apropriação intencional, o autor que retoma textos precedentes quer que o leitor reconheça a alusão e decodifique sua mensagem, sentindo assim o prazer de que Aristóteles já falava em suas considerações sobre a mímesis. Está na Poética, em sumário, no primeiro parágrafo do capítulo IV, o prenúncio do processo criativo que impulsionaria as literaturas latina e renascentista:

13. Ao que parece, duas causas, e ambas naturais, geraram a poesia. $O$ imitar é congênito no homem (e nisso difere dos outros viventes, pois, de todos, é êle o mais imitador, e, por imitação, apreende as primeiras noções) e os homens se comprazem no imitado. ${ }^{120}$

\footnotetext{
${ }^{118}$ Op. cit., p. 130 .

119 Ibidem, p. 148.

120 ARISTÓTELES. Poética. Tradução de Eudoro de Souza. Porto Alegre: Globo, 1966. Grifos nossos.
} 
A partir da reflexão do estagirita, entendemos que são quatro os elementos básicos da arte mimética: o exemplo a imitar; o imitador; a obra de imitação; e aquele que se compraz no imitado. Igualmente, na "arte alusiva" temos os textos exemplares, que são evocados; o poeta, doctus imitator; a obra literária, produto da imitação; e o leitor, o doctus lector, que se compraz no reconhecimento do imitado.

$\mathrm{Na}$ Antigüidade, o reconhecimento, ou seja, a percepção da intertextualidade fazia-se de modo mais fácil, pois que se aprendia a língua grega na escola, através de textos exemplares que deveriam ser memorizados. Na Itália humanista, o estudo dos textos produzidos pelos antigos e a revalorização de sua cultura e, ainda, o incentivo ao ensino das línguas grega e latina, fazem reacender o interesse por aquela literatura douta do passado. No Renascimento, a versão para o vernáculo de textos gregos e latinos torna possível a expansão do conhecimento literário. Toda essa imersão na cultura clássica acaba por conduzir à reprodução do processo de criação literária praticado pelos latinos, a imitatio. Vale lembrar que a língua italiana se estabelece através da literatura. Assim, quando temas da literatura nacional, já arraigados na memória, são tomados a Dante, Pretarca, Boccaccio, e também os temas medievais, como os das narrativas do ciclo carolíngeo, e incorporados aos da literatura renascente, são facilmente reconhecidos. Isso, somado ao coloquialismo da linguagem do teatro - primeiro gênero imitado aos antigos - e à difusão da imprensa, faz levar o referente literário a um número mais elevado de pessoas do que o que, possivelmente, se viu em Portugal, apesar dos esforços de seus governantes para integrar o país à "Europa culta". O que se observa é que, nesse momento de transbordamento intelectual na Itália, Portugal permanece apegado às suas próprias tradições, tanto que Sá de Miranda, quando escreve sua primeira comédia, precisa explicar no prólogo que gênero é esse, traçando uma espécie de histórico da Comédia desde seu surgimento na Grécia. Precisa ainda apresentar Ariosto, poeta já ilustre quando de seu retorno a Portugal, àquele que será seu protetor em sua empreitada classicizante, o Infante Cardeal Dom Henrique, e explicar o processo criativo da imitatio para que seu texto não seja mal interpretado e tomado como "furto". Ora, se a própria nobreza não estava preparada para tal tipo de arte literária, quem seria aquele leitor-decodificador do jogo alusivo em Portugal do começo do Quinhentos? Escreveria Sá de Miranda pelo próprio prazer de 
reconhecer-se como erudito? O fato é que, se Sá de Miranda escreve, nesse primeiro momento, para meia dúzia de letrados, e é incompreendido pela maioria inculta, mesmo na corte, ele abre uma porta para que os novos ideais de arte se instalem em Portugal e sejam abraçados por novos poetas, como António Ferreira e Camões, o aedo dos heróicos lusíadas - lembrando que tanto a Castro quanto Os Lusíadas são obras que resgatam valores portugueses, da história e da tradição de Portugal.

Para o leitor dos textos da Antigüidade Clássica hoje, aquele nível de percepção intertextual dos antigos torna-se impossível, pois grande parte dos textos gregos, ou mesmo do latim arcaico, a que os escritores latinos aludem, se perdeu e não pode ser confrontada, e certas sutilezas das alusões passariam despercebidas por não encontrarem o respaldo cultural que tinha o leitor antigo. No caso dos textos renascentistas, buscar o confronto com os modelos é tarefa penosa mas praticável, pois o que chegou até aquele momento foi, de alguma forma, preservado até nossos dias, se não no original, através de traduções e estudos críticos.

Quanto à análise e interpretação desses textos, cabe-nos ainda, antes de terminarmos este capítulo, tocar numa última questão, a nosso ver, um tanto controversa: a questão da "originalidade" em poesia douta - como avaliar o quão original um poeta pode ser dentro dos limites impostos pelo gênero poético ao qual filia sua composição. Dissemos que a questão é controversa porque nos parece uma contradição buscar originalidade numa poesia que é, desde a sua concepção, imitativa e deve se encaixar numa fôrma genérica, com fórmulas prontas e convenções peculiares, restringindo seus temas aos que são próprios desse gênero. Talvez "criatividade" fosse um termo mais adequado para designar a engenhosa maneira como o poeta dribla a realidade poética em que está inserido. Um poeta pode ser criativo de diversas formas, além das já identificadas no jogo alusivo, ao buscar diferenciar sua obra. Cairns ${ }^{121}$ define quatro categorias sob as quais, de modo geral, se pode observar a "originalidade" (criatividade) em composições genéricas. Na primeira, diz Cairns, a novidade se apresenta pela "introdução em um modelo genérico de topoi e noções até então não associados a ele." A segunda

\footnotetext{
${ }^{121}$ CAIRNS, Francis. Generic Composition in Greek and Roman Poetry. Edinburgh: Edinburgh University Press, 1972, p. 99.
} 
categoria diz respeito à "própria escolha, combinação e arranjo dos topoi comuns a um gênero particular". Na terceira, são observadas as "alterações e modificações" que o poeta faz em cada topos separadamente. E a quarta, trata do "emprego pelo escritor de sofisticações genéricas importantes, que são potencialmente aplicáveis a todos os gêneros." Note-se que a primeira categoria inclui o jogo alusivo, pois os "topoi e noções" não associados a um gênero que o poeta introduz em seu texto podem aludir a outros gêneros, sugerindo uma relação, no mínimo, entre contextos. Vemos, assim, que também através de relações intertextuais o poeta consegue escapar às restrições genéricas.

Este aspecto da criação poética, a criatividade na composição de um gênero, também será considerado em nossa análise dos textos de Sá de Miranda. Se o poeta português fez uso de todos os recursos que o processo criativo da imitatio possibilita e se bem aproveitou a herança clássica que lhe coube, saberemos depois de procedermos à análise. Faz-se necessário, agora, apresentar essa herança: quais foram os modelos que ele herdou e imitou e como se caracteriza o gênero ao qual se filiou. 


\section{A herança clássica}

\section{O teatro latino}

\subsection{Origem}

A origem do teatro latino não é diferente da origem do próprio teatro, cujas manifestações primitivas estão ligadas às danças de fertilidade e colheita, aos mais diversos cultos divinos, enfim, aos impulsos vitais do homem.

O primeiro registro de manifestação teatral em Roma - o que não significa que não houvesse alguma manifestação do teatro romano anteriormente - diz respeito à origem dos Iudi scenici. Segundo Tito Lívio (Ab Vrbe Condita, VII, 2), os jogos teatrais surgiram em Roma por razões religiosas e foram dedicados aos deuses. Conta o historiador que uma grande peste assolava a cidade e já se estendia pelo segundo ano seguido (364 a.C.), dizimando a população, apesar dos esforços - incluindo oferendas aos deuses, como o lectisternium ${ }^{122}$ - empreendidos para exterminá-la:

... e como a violência da moléstia não era abrandada nem por expedientes humanos nem pela ajuda divina, ficando os espíritos entregues à superstição, diz-se que, entre outros meios para aplacar a ira celeste, foram instituídos também os jogos cênicos [ludi scenici] - novidade para aquele povo belicoso, pois o espetáculo de circo havia sido o único até então. ${ }^{123}$

Para esses jogos foram trazidos ludiones - dançarinos, músicos e mimos da Etrúria - que, "sem cantar, dançavam ao ritmo da flauta com movimentos graciosos,

\footnotetext{
${ }^{122}$ Banquete solene que se oferecia aos deuses, colocando suas estátuas em ricos leitos em volta da mesa (SARAIVA, 2000).

123 "...et cum uis morbi nec humanis consiliis nec ope diuina leuaretur, uictis superstitione animis ludi quoque scenici - noua res bellicoso populo, nam circi modo spetaculum fuerat - inter alia caelestis irae placamina instituti dicuntur..."
} 
à maneira etrusca." Ainda conforme o relato de Tito Lívio, os ludiones passaram a ser imitados pelos jovens romanos, que criavam versos rudes para gracejar e, em vez de movimentos de dança a acompanhar o ritmo da música, gesticulavam de acordo com o que os versos diziam. A brincadeira dos jovens foi aceita e mantida, incorporando-se aos costumes.

Aos artistas locais foi dado o nome de histriões, porque de ister era chamado o ator na língua etrusca; estes não mais, como antes, lançavam ao acaso rudes versos improvisados, semelhantes aos fesceninos, mas representavam sátiras [misturas] cheias de melodias ritmadas, com um canto agora regulado para a flauta e com gestos em harmonia. ${ }^{124}$

Quanto aos versos fesceninos, aos quais Tito Lívio se refere como sendo a gênese do teatro latino, podem ter sido assim designados por conta do nome da cidade etrusca de Fescennia, mas, segundo Mendes, ${ }^{125}$ admite-se a possibilidade de o nome derivar do vocábulo fascinum, que significa mau-olhado, que se acreditava poder afastar com os versos. Foster ${ }^{126}$ sugere que derive do mesmo vocábulo fascinum, mas no sentido de símbolo fálico. Esta acepção de fascinum como uirile membrum ${ }^{127}$ é dicionarizada - segundo Saraiva, foi usada por Horácio e, parece-nos, faz sentido que a designação dos versos derive daí, pois que esses versos eram insultuosos e impregnados de licenciosidade obscena.

Também Horácio faz remontar aos fesceninos a origem do teatro romano. Em Epístolas, II,1, fala dos antigos camponeses que, tão logo terminavam de preparar a terra e repor os grãos, festejavam com seus companheiros, mulheres e filhos, sacrificando um porco e oferecendo leite ao deus Silvano ${ }^{128}$ e flores e vinho ao Gênio, ${ }^{129}$ com vistas a obter uma boa colheita: "Por este costume, estabeleceram-se os licenciosos cantos fesceninos / que, em versos alternados, lançavam insultos

\footnotetext{
124 "Vernaculis artificibus, quia ister Tusco uerbo ludio uocabatur, nomen histrionibus inditum; qui non, sicut ante, Fescennino uersu similem incompositum temere ac rudem alternis iaciebant sed impletas modis saturas descripto iam ad tibicinem cantu motuque congruenti peragebant."

125 MENDES, Andréa Cristina. O Espetáculo Teatral Romano e a Peça Otávia. Dissertação de mestrado, FFLCH-USP, 2001, p. 11.

${ }^{126}$ FOSTER, B. O. Em nota à sua tradução de Ab Vrbe Condita: LIVY. From the founding of the city. Vol. III (Books V-VII). London: Willian Heinemann Ltd, 1984, nota 3, p. 361.

${ }^{127}$ SARAIVA, F. R. dos Santos. Novíssimo Dicionário Latino-Português. Rio de Janeiro: Garnier, 2000.

${ }^{128}$ Protetor dos bosques.

${ }^{129}$ Espírito responsável pelo poder gerador de cada homem.
} 
rústicos." ${ }^{130}$ Espécie de desafio, como os dos repentistas brasileiros, os fesceninos eram cantados também por ocasião das festas de casamentos - sempre houve uma estreita relação entre obscenidade e fertilidade com o grotesco e o burlesco, basta lembrar Priapo, o deus de enorme falo, ao mesmo tempo venerado como deus da fertilidade e vítima de escárnio por conta de sua obscena deformidade. ${ }^{131}$ Há que se lembrar, também, que Teócrito de Siracusa, no século III a.C., compôs versos bucólicos para serem cantados em desafio, os seus Idílios - mais tarde imitados por Virgílio - inspirados nos cantos sicilianos em honra aos deuses do campo e nos mimos de Sófron, fato que nos leva a inter-relacionar os dois tipos de manifestações, e que sugere uma origem comum.

$\mathrm{Na}$ mesma linha entre o burlesco, o obsceno e o grotesco está a hilarotragoedia. Nascida na colônia grega de Taras, em Tarento, importante centro teatral da Itália, por volta de 350 a.C., a hilarotragoedia - literalmente, tragédia engraçada - parodiava a tragédia grega. Seus atores, os flíacos, eram trocistas que abusavam de enchimentos para formar falos enormes ou imitar pessoas obesas de forma grotesca, com o objetivo de alcançar maior efeito cômico. É possível que as paródias flíacas tenham exercido influência sobre as manifestações teatrais populares em Roma, como sugere Moussinac, especialmente sobre a farsa atelana. ${ }^{132}$ Essa influência, segundo o estudioso, teria garantido "uma espécie de transição entre o teatro grego e o latino."133

Entre as brincadeiras cênicas primitivas apresentadas nos jogos constava também o mimo, farsa burlesca improvisada, desenvolvida originalmente na Sicília, representada por atores saltimbancos que imitavam pessoas comuns do povo, figuras velhacas encontradas em qualquer lugar: ladrões, alcoviteiras, cortesãs, entre outras, e animais, especialmente o asno - animal carregado de simbolismo cômico desde tempos imemoriais -, todos caricaturados pelos mimos, que eram os atores e atrizes desse teatro (as mulheres não eram admitidas em outros tipos de encenação). Os mimos romanos não usavam máscaras, vestiam-se como a gente

\footnotetext{
130 "Fescennina per hunc inuenta licentia morem / uersibus alternis opprobia rustica fudit." (v. 145-6).

${ }^{131}$ Sobre a priapéia grega e latina, ver OLIVA NETO, João Angelo. Falo no jardim. Tese de doutoramento, FFLCH-USP,1999.

${ }_{132}$ MOUSSINAC, Léon. História do Teatro - das origens aos nossos dias. Tradução de Mário Jacques. Amadora: Livraria Bertrand, [s.d.], p. 72.

${ }^{133}$ Ibidem, p.74.
} 
das ruas e eram, ao mesmo tempo, músicos e dançarinos, acrobatas e malabaristas, e representantes da mais pura arte mimética. Criação mais antiga e mais duradoura do que a comédia, o mimo - que recebeu forma literária por Sófron de Siracusa em torno de 430 a.C. - atravessou todo o período teatral romano, sobrevivendo às crises políticas que acabaram por fechar os teatros e proibir as representações teatrais, e chegou até a Idade Média.

Pouco se sabe sobre essas manifestações do teatro primitivo romano. Algumas referências, como as encontradas em Tito Lívio e Horácio, uns poucos fragmentos, pinturas em vasos, são esses os elementos que levam os estudiosos a reconstituir sua história e trajetória. Mas é certo que, desde suas origens, o teatro latino esteve sempre relacionado aos ludi, jogos públicos, e era apresentado nas festas romanas juntamente com outros tipos de espetáculos, como as lutas de gladiadores, corridas de carros e competições diversas, bem característicos do espírito romano, guerreiro e competitivo, embora não sejam uma invenção romana muito antes de serem introduzidos nos ludi romani, os espetáculos de lutas, assim como os teatrais, já eram comuns entre os etruscos.

Não havendo uma festa específica para a representação teatral, diferentemente dos festivais de teatro gregos, o teatro romano também não contava com um espaço especificamente seu, sendo representado no mesmo espaço em que se apresentavam os outros jogos. O palco era montado para a encenação e desmontado após o seu término. A primeira tentativa de um teatro fixo, de pedra, ocorre em 155 a.C. sem sucesso, pois ainda não se aceitava em Roma o teatro instalado. Deve-se a Pompeu o estabelecimento do primeiro teatro de pedra romano, erguido em 55 a.C. no Campus Martius. Sobre o interesse de Pompeu na construção de um teatro permanente e como alcançou seu intento, conta Berthold, na sua História Mundial do Teatro:

Pompeu se impressionara muito com os teatros gregos durante suas várias campanhas marítimas e terrestres. Lesbos Ihe parecia um modelo ideal quando, durante seu consulado em 55 a.C., obteve permissão das autoridades em Roma para edificar um teatro de pedra. Usando de um inteligente estratagema, ele afastou o perigo de o teatro ser demolido depois dos jogos: acima da última fileira do anfiteatro semicircular, ergueu um templo 
para Vênus Victrix, a deusa da vitória. Os assentos de pedra - ele argumentou - eram o lance de escadas que levavam ao santuário. ${ }^{134}$

Tácito conta (Anais, XIV, 20), traçando uma comparação com a instituição por Nero dos "jogos qüinqüenais ao modo dos gregos", que esse ato de Pompeu, à sua época, não foi visto com bons olhos pela opinião pública, que acreditava que o fato de não mais se assistir às encenações de pé poderia levar o espectador ao ócio. Novidades eram recebidas com o receio de que pudessem acarretar a degradação dos costumes:

Assim é que alguns recordavam ter sido $\mathrm{Cn}$. Pompeu muito censurado em seu tempo por ter construído um teatro permanente. Porquanto os espetáculos eram dados antes disso em cenários improvisados na ocasião, e em época ainda anterior o povo assistia de pé, para que a ociosidade não o conservasse dias inteiros no teatro. Deviam-se conservar, diziam, o costume antigo dos espetáculos dados pelos pretores, em que os cidadãos não eram obrigados a disputar prêmios. Assim aos poucos ir-se-iam abolindo, com a adoção de práticas forasteiras, as pátrias usanças, de sorte que em Roma viesse a ter guarida quanto no mundo fosse meio de corrupção, e a mocidade, dada ao ócio, [...] de todo degenerasse ... ${ }^{135}$

No que diz respeito ao teatro propriamente dito, entendido como o conjunto de encenação e texto previamente escrito, o teatro latino que podemos estudar hoje é o que foi imitado da Comédia Nova e da Tragédia gregas, paradigmas utilizados pelo teatro mundial mais tarde, do Renascimento aos nossos dias.

Também sobre o início da imitação romana do teatro grego e a sua recepção pelos romanos, encontramos o registro de Tito Lívio na seqüência de seu relato sobre as primeiras manifestações teatrais em Roma:

Lívio, ${ }^{136}$ alguns anos depois, foi o primeiro a abandonar as sátiras e compor uma peça com argumento. Diz-se que foi também, como todos eram naquela época, ator de suas próprias peças e que, por ser freqüentemente chamado de volta à cena, sua voz enfraqueceu. Pediu e obteve, então, permissão para colocar diante do flautista um jovem para cantar, enquanto ele, não tendo mais que se preocupar com a própria voz, representava com movimentos mais vivazes. Desde então os histriões começaram a usar cantores para

\footnotetext{
134 São Paulo: Perspectiva, 2001, p. 151.

${ }^{135}$ TÁCITO. Anais. Tradução e prólogo de Leopoldo Pereira. Rio de Janeiro: Ediouro, [s.d.], p. 217.

${ }^{136}$ Refere-se a Lívio Andronico, escravo grego, capturado em Tarento, que fez a primeira tradução para o latim de peças teatrais gregas, assim como da Odisséia, dando início à literatura latina em 240 a.C.
} 
acompanhar seus movimentos, deixando suas próprias vozes para os diálogos. Desde que esse sistema foi adotado, as representações afastaramse do riso e dos gestos livres e o teatro transformou-se, pouco a pouco, em arte. Os jovens, então, deixaram as representações teatrais para os histriões e retomaram o costume antigo de improvisar gracejos entremeados com versos. Daí surgiram as pequenas representações, mais tarde chamadas de êxodos, que foram relacionadas sobretudo com as fábulas atelanas, um gênero de espetáculo herdado dos oscos, do qual a juventude se apossou, não permitindo que fosse violado pelos histriões ... 137

Embora tenha existido em Roma um teatro com bases não-gregas, com ambientação e assunto romanos, como se verá no próximo tópico, a única influência essencialmente latina para o teatro mundial parece ter sido a das atellanae, espécie de farsa que provavelmente deu origem à Commedia dell'Arte, teatro que divide com o de origem grega o mérito de ter sido a base do teatro moderno.

É possível, com esses dados, concluir-se que a comédia imitada dos gregos por Plauto e Terêncio, entre outros comediógrafos cujas obras não chegaram até nós, não fosse tão popular quanto as outras manifestações teatrais essencialmente burlescas, padrão de humor para o romano comum. Pode-se, mesmo, depreender do relato de Tito Lívio que a fabula atellana se afirma como reação dos jovens latinos ao teatro importado da Grécia. Interesses diferentes moviam os povos grego e romano. A recepção da comédia de modelo grego pelos romanos deve ter sido como a de algo estranho, fora de contexto, algo que exigisse um conhecimento prévio da cultura e dos modelos gregos para ser compreendido. Era, possivelmente, uma comédia quase tão erudita para eles quanto foi, mais tarde, sua imitação para o público do Classicismo. Sabe-se que na primeira representação da Hecyra, de Terêncio, o público abandonou a platéia para assistir a pugilistas e equilibristas. As peças de Plauto, porém, que misturavam elementos do mimo, da farsa atelana e de outras manifestações populares, com alguma obscenidade, parecem ter atraído mais a atenção do público do que as de Terêncio.

\footnotetext{
137 "Liuius post aliquot annis, qui ab saturis ausus est primus argumento fabulam serere, idem scilicet - id quod omnes tum erant - suorum carminum actor, dicitur, cum saepius reuocatus uocem obtudisset, uenia petita puerum ad canendum ante tibicinem cum statuisset, canticum egisse aliquanto magis uigente motu, quia nihil uocis usus impediebat. Inde ad manum cantari histrionibus coeptum, diuerbiaque tantum ipsorum uoci relicta. Postquam lege hac fabularum ab risu ac soluto ioco res auocabatur et ludus in artem paulatim uerterat, iuuentus histrionibus fabellarum actu relicto ipsa inter se more antiquo ridicula intexta uersibus iactitare coepit; unde exorta quae exodia postea appellata consertaque fabellis potissimum Atellanis sunt; quod genus ludorum ab Oscis acceptum tenuit iuuentus nec ab histrionibus pollui passa est ..."
} 
Para concluir este tópico, observamos que Tito Lívio distingue cinco estágios no desenvolvimento do espetáculo cênico romano, que são, nos termos de Foster,

(1) danças, acompanhadas pela flauta; (2) improvisação de versos rudes somados à música e à dança; (3) misturas [saturae], de caráter musical, acompanhadas por flauta e dança; (4) a comédia com um enredo regular, cantores especiais para as partes líricas, etc.; (5) o acréscimo de uma pequena peça após a peça principal, exodium ou Atellana. ${ }^{138}$

\subsection{Os gêneros teatrais em Roma}

Os textos dramáticos latinos eram denominados fabulae (fábulas), que significa narrativas. Todo espetáculo cênico que narrasse uma história, ou seja, que tivesse um enredo ou intriga, era uma fabula.

O palco de Roma recebeu três gêneros de fabula com ambientação e assunto romanos - a fabula atellana, a fabula togata e a fabula praetexta - e um que imitava a Comédia Nova Grega - a fabula palliata.

A fabula atellana, um dos gêneros cômicos, foi assim denominada por ter, provavelmente, sido criada na cidade de Atella, na Campânia, sul da Itália. Era um tipo popular de farsa, cantada e dançada, que, como dissemos anteriormente neste trabalho, está possivelmente na origem da Commedia dell'Arte. Como esta, ela também não era escrita, era improvisada e contava com personagens-tipo fixos:

- Maccus: um tipo rústico, mas malicioso;

- Bucco: beberrão e, por isso, um tipo falador e fanfarrão;

- Pappus: um velho rabugento ou ingênuo, objeto de chacota e vítima de trapaças.

- Dossenus: um tipo parasita e glutão, dado a filosofar, e objeto de zombaria.

${ }^{138}$ Op. cit., nota 2, p. 360. 
Esses personagens-tipo, identificados por máscaras próprias, têm características semelhantes às de alguns dos caracteres traçados por Teofrasto do que trataremos mais adiante - que se tornaram os tipos da Comédia Nova Grega, e é possível que tenham sido contaminados por essa cultura. As trapalhadas que esses personagens faziam, chamadas pelos estudiosos do teatro de disfarces e equívocos, é que originavam a intriga da peça. E a origem da palavra "intriga" pode vir daí: a estes disfarces e equívocos se dava o nome de tricae atellanae. ${ }^{139}$

Representada originalmente em osco, a comédia atelana recebeu forma literária mais tarde, por volta de 90 a.C., quando já havia uma literatura desenvolvida em Roma, pelos escritores Pompônio e Nóvio. É a eles que devemos o conhecimento que temos hoje dessa comédia, conforme relata Moussinac:

Alguns fragmentos de Pompónio e Nóvio, citados por gramáticos, dão-nos uma ideia do movimento, da fantasia e do sabor de um diálogo no qual o emprego do verso fescénio e a mistura do dialecto osco e do latim facilitam a naturalidade e definem a originalidade. Quanto aos assuntos das atelanas, eles inspiram-se nos incidentes vulgares da vida dos camponeses e nos ridículos dos citadinos. Descrevem situações pouco verosímeis, mas que permitem um tal choque de personagens que o riso estala como que provocado mecânicamente, enquanto o cinismo das falas e a sua obscenidade fazem-Ihe prolongar o êxito. ${ }^{140}$

As atellanae, como depois os mimos, eram encenadas no final de um espetáculo principal e por isso eram chamadas exodia (fim, conclusão), como visto no tópico anterior, pelo relato de Tito Lívio. Tinham o papel de fazer descansar o público, ao modo dos dramas satíricos gregos que se apresentavam entre as peças encenadas nas competições teatrais, e já eram bastante populares em Roma no século III a. C., quando se acentua a influência da literatura grega sobre os romanos. É a partir desse período, no final da Primeira Guerra Púnica, que passa a existir oficialmente uma literatura latina. E, juntamente com a tradução da Odisséia de Homero, o marco inicial da literatura latina é justamente a versão para o latim de

\footnotetext{
${ }^{139}$ Encontramos esta afirmação em VASCONCELLOS, Luiz Paulo. Dicionário de Teatro. São Paulo: L\&PM Editores, 1987, p. 88. Alguns estudiosos não concordam com ela.

${ }^{140}$ Op. cit., p. 71-72.
} 
uma tragédia e uma comédia gregas, por Lívio Andronico, que foram apresentadas num dos ludi romani, em 240 a.C. ${ }^{141}$

Fabula palliata é a comédia cujo assunto é o cotidiano do homem grego comum. O uso do pallium - espécie de manto comum ao vestuário grego - pelos seus atores é o responsável pela denominação palliata. É uma imitação da Comédia Nova Grega, em latim, adaptada para os costumes romanos. A palliata foi o gênero de comédia que serviu de modelo aos autores renascentistas e por essa razão será tratada à parte, mais adiante.

Da fabula togata, comédia que surge posteriormente ao "período áureo" da palliata, quase nada restou senão referências, uns poucos títulos e fragmentos. Sabe-se que era uma comédia ambientada em Roma e que discutia problemas locais, fazendo sátira social em tom de farsa. É provável que se tenha originado "da necessidade do público de ver discutidos no palco problemas e situações locais." 142 Chamou-se togata por conta do uso da toga, que era o traje romano comum.

No mesmo período em que se representou a comédia palliata, encontramos em Roma um gênero sério de teatro, a fabula praetexta. Ambientada em Roma, esta também tem seu nome tirado da veste usada no palco, a toga praetexta, que era a veste característica dos magistrados e aristocratas romanos. Da praetexta, chegou até nós uma única peça, atribuída a Sêneca, com o título Otávia.

Inspirada em fato histórico relativo à sua época, a fabula praetexta tinha assunto romano tratado de forma séria. A representabilidade dessa fabula, como a das tragédias de Sêneca, é discutível. Mas a maior questão levantada por esse caso não deve ser a da dificuldade do texto para a representação, mas a quem o teatro romano se destinava e o que levava o público romano ao teatro.

As representações teatrais em Roma não tiveram o mesmo espírito educativo e cultural que animou o teatro grego. Ao contrário, o poder estabelecido em Roma esforçava-se por manter a plebe na ignorância, oferecendo-lhe "pão e circo", acreditando que, desse modo, seriam evitadas conspirações. Os jogos, ludi romani,

\footnotetext{
${ }^{141}$ Há autores que falam da Odisséia como sendo a primeira tradução de Lívio Andronico e o marco inicial da literatura latina; outros dizem que foi uma tragédia e outros, que, no mesmo período, ele traduziu uma comédia e uma tragédia para os ludi, além da Odisséia.

${ }^{142}$ VASCONCELLOS, Luiz Paulo, op. cit., p. 89. A palavra "palco" encontra-se destacada em letras maiúsculas no texto da autor, por ser chamada para o verbete.
} 
promovidos para comemorar os triunfos romanos, tinham como segunda intenção manter o povo iludido e alegre. Por isso, a representação de peças de assunto sério deveria ficar restrita a uma platéia de uns poucos doctores. A peça Otávia é a única representante da praetexta, entre as seis de que se tem notícia, conservada até hoje. O uso da toga praetexta indicava que seus personagens eram nobres e magistrados, aqueles que se vestiam com esse tipo de manto. É possível que esse gênero teatral tenha sido criado por membros da aristocracia romana justamente para que fosse celebrada a sua nobreza. ${ }^{143}$

\section{A fabula palliata}

Imitação romana de textos gregos, a comédia latina do tipo palliata não pode ser analisada sem um conhecimento prévio daquela que lhe serviu de modelo, a Comédia Nova Grega. A existência de farto material a respeito da Nova torna possível o seu estudo, ainda que parco material de um único autor grego, Menandro, tenha resistido ao tempo e chegado aos nossos dias com "identidade dramatúrgica definida e consistente": ${ }^{144}$ O Misantropo (Dyskolos), comédia praticamente inteira, em que faltam somente alguns versos; O Escudo (Aspis), em que se perdeu todo o ato $\mathrm{V}$ e do ato IV restam apenas fragmentos; e outras três em estado bastante fragmentário, mas das quais se pode inferir o enredo: O Árbitro (Epitrepontes), A Mulher Careca (Perikeipomene) e A Mulher de Samos (Samia). ${ }^{145}$ As próprias comédias latinas de Plauto e Terêncio são fontes preciosas de informações sobre a Nova, especialmente porque no prólogo seus autores costumavam indicar que autor grego e quais comédias serviram de base às suas e, embora o confronto com os textos originais seja impossível, a partir dos textos latinos nos é dado conhecer os

\footnotetext{
${ }^{143}$ Cf. MENDES., op. cit., p. 61.

${ }^{144}$ PADUANO, Guido. Introduzione. In: MENANDRO. Commedie. Milano: Oscar Mondadori, 2004, p. xxx. Segundo o autor, restam de algumas outras peças um número de versos próximo ao de Aspis e de Perikeiromene, mas que não permitem "testemunhar sem incerteza os momentos dramáticos essenciais ao devir dramático."

${ }^{145} \mathrm{~A}$ tradução para o português dos três últimos títulos é nossa. Desconhecemos traduções brasileiras ou portuguesas destas peças.
} 
métodos utilizados na imitação "em segundo grau", ou seja, no processo de recriação dessas obras literárias.

Já as comédias de Menandro traziam, com freqüência, alusões às peças de Aristófanes, além de aludir a tragédias, à mitologia e a lugares-comuns da épica e da literatura grega em geral, como em $O$ Escudo, que, desde o título até a fala do escravo Davo, na abertura da peça, evoca duas tradições: uma do mundo militar grego, que se tornou topos literário - a do dever do soldado de não abandonar o escudo (vide Arquíloco, Fr. 38W, que testemunha contra si mesmo ao declarar em versos ter abandonado seu escudo, versos que foram citados por Aristófanes na comédia $A$ Paz) - e a dos guerreiros homéricos, que tinham o escudo como "baluarte dos dardos inimigos", ${ }^{146}$ mais uma demonstração de que entre os gregos a arte alusiva era comum. Os empréstimos, quer de temas, quer de versos inteiros, a autores consagrados enriqueciam obras de todos os gêneros na Grécia e, desde o período arcaico, Homero foi uma grande fonte, da qual poetas e filósofos se serviram.

Aristófanes, antes de Menandro, já citava em suas comédias autores épicos, líricos e trágicos, colocando seus versos num contexto completamente diferente do original, o que promovia uma mudança de sentido de efeito cômico (paródico), como o fez com os citados versos de Arquíloco ${ }^{147} \mathrm{e}$, entre outros, com o verso da tragédia Telefo, de Eurípides, que coloca na voz da personagem Pobreza, na comédia Pluto e que ora apresentamos como exemplo. Demonstrando racionalmente que a pobreza tem mais valor do que a riqueza, entre outros motivos, porque a pobreza leva à virtude, enquanto a riqueza leva seus possuidores ao vício da avareza, a Pobreza tenta convencer Cremilo, que tem Pluto, o deus da riqueza, hospedado em sua casa, a expulsá-lo e a deixá-la tomar o seu lugar. O hospedeiro do deus encerra o debate:

\footnotetext{
${ }^{146}$ Cf. PADUANO. Note, op. cit., p. 334.

${ }^{147}$ Embora os versos de Arquíloco já tratem na lírica a tradição do escudo com descaso e em tom satírico, com o seu deslocamento para a comédia de Aristófanes, eles ganham um novo sentido: o de abandono da guerra pela vitória da paz. Eis os versos citados n'A Paz: "Algum soldado Saiano / agora está todo prosa / com aquele escudo glorioso / que tive de jogar fora." Trad. de Mário da Gama Kury, Rio de Janeiro: Ediouro, [s.d.], p. 79.
} 
Cre.: - ... vá para o inferno e não soltes mais palavras, porque não me convencerás, ainda que me hajas convencido.

A isso responde a Pobreza, em tom trágico, evocando Eurípides:

Pobreza: - "Ouvis o que disse, habitantes de Argos?"148

Esse deslocamento do verso de seu contexto trágico, de tom elevado, para o da comédia, onde preside a ironia, promove, com o efeito intertextual, um estranhamento que provoca o riso.

Em As Rãs, entre tantas outras alusões às tragédias de Eurípides que Aristófanes faz na peça, um verso de Orestes é citado pelo escravo Xântias, que o torna ridículo pela maneira de pronunciá-lo: "Depois da tempestade vejo o gato."149 Kury, o tradutor, explica: "Toda a graça decorre da confusão no original entre galén (gato) e galén' (calmaria), em que há uma contração da letra final da palavra galéne."

N'As Vespas, evoca - e parodia - o canto IX da Odisséia, ao fazer o velho Filoclêon tentar escapar à vigilância do filho, Bdeliclêon, agarrado à barriga de um asno, como Odisseu agarrado à barriga da ovelha para fugir da caverna do ciclope, reproduzindo até o diálogo entre este último e o herói grego:

Bdeliclêon: - ... Quem é você?

Filoclêon: - Ninguém. ${ }^{150}$

O mesmo tipo de alusão fazia Plauto para evocar, no meio da comédia, um texto de gênero elevado, parodiando-o. Assim o fez, por exemplo, ao colocar na voz do escravo Crísalo, da peça Bacchides, versos da tragédia Andrômaca de Ênio, para

\footnotetext{
148 ARISTÓFANES, Comedias (Los caballeros, La paz, Las avispas, Pluto). Valencia: Prometeo, [s.d.], p. 219. tomo segundo.

${ }_{149}$ ARISTÓFANES. As Vespas. As Aves. As Rãs. Tradução do grego, introdução e notas de Mário da Gama Kury. Rio de Janeiro: Jorge Zahar, 1996, p. 225. A explicação que se segue vem na nota 27, p. 290.

${ }^{150}$ Ibidem, p. 22.
} 
comparar a grandeza de seu feito - tentativa de arrancar dinheiro ao velho patrão à dos astutos heróis gregos na guerra de Tróia: "Ó Tróia, ó pátria, ó Pérgamo ..." 151 Na cena anterior da mesma peça, Plauto já havia evocado a llíada, aludindo a vários de seus personagens e episódios.

Pelo fato de a arte alusiva permear toda a literatura da Antigüidade, consideramos necessário observar como as Poéticas da Antigüidade tratavam as questões da imitação e da "originalidade" na literatura daquele período. Entendemos por "originalidade" a maneira criativa com que um escritor ludibria as restrições do gênero a que filia sua obra e com que se utiliza de textos precedentes para produzir uma obra nova, portanto, inédita, e não somente o ineditismo da representação de uma realidade jamais imitada. ${ }^{152}$ Por imitação, compreende-se a arte de representar ou recriar tanto o que se encontra na natureza, como outra obra literária. Especialmente no que toca à literatura latina, cuja origem se vincula diretamente à reelaboração de textos gregos, e especificamente no caso da palliata, em que das vinte e seis comédias latinas completas que conhecemos, vinte de Plauto e seis de Terêncio, todas são imitações de peças gregas, essas questões têm que ser abordadas.

\subsection{As Poéticas e a imitação}

A Poética de Aristóteles trata dos gêneros literários como imitação da natureza, como imitação das ações dos homens. Pelo pensamento aristotélico, em qualquer das artes, a mímesis se dava nesse sentido, a partir do que estava na natureza, no mundo sensível, no qual o homem age. Isto é que servia de exemplo, de modelo para o artista. Longe da idéia platônica da imitação do poeta como deformação do modelo - por estar "três vezes" afastada do plano inteligível onde residem as formas ideais, prescindindo da razão e, portanto, dissociada do conhecimento -, para Aristóteles a imitação era, sim, fonte de conhecimento, pois os

\footnotetext{
151 "O Troia, o patria, o Pergamum..." Vasconcellos também cita este exemplo, op. cit., p. 40.

152 Daí o destaque dado ao termo, que denota também - e, quase sempre, acima de tudo -a característica de não ser copiado de nenhum modelo.
} 
homens aprendem imitando e na imitação se comprazem. A catarse no teatro é exemplo significativo de que o homem "aprende" com a arte. Além disso, para Aristóteles poesia é técnica e pode ser aprendida. Ele não acredita no poeta inspirado, que profere seu discurso em transe, fora da razão. O bom poeta exercitase numa técnica.

A Arte Poética de Horácio trata da imitatio como recriação, como literatura "em segundo grau", pois a literatura que os romanos vinham produzindo, desde seus primeiros contatos com a literatura grega, era uma imitação daquela imitação a que se refere Aristóteles, ou seja, trata de uma imitação indireta da vida - embora tenhamos visto que a prática da alusão a obras precedentes e já consagradas fosse comum entre os gregos.

Para Horácio, tratar um tema conhecido com perfeição é melhor do que cair nas armadilhas da invenção: “... e tu, com mais segurança, reduzes a atos o poema llíaco, do que, se por primeiro, publicasses o que é desconhecido e inédito". ${ }^{153}$ Para produzir essa literatura imitativa era preciso ter mais do que o ingenium (talento natural), era preciso dominar a ars (técnica), o mais importante para alcançar a perfeição e a excelência poética. Sua obra é um tratado de como imitar bem, que estabelece regras para se chegar ao belo ideal, é um manual de estética da arte imitativa, de recriação, que seria retomado no Renascimento. Seus conceitos ecoam na obra de teóricos do classicismo, como podemos observar, por exemplo, na Carta XII de António Ferreira, imitação da Epístola aos Pisões.

O romano antigo era um homem rude, prático, mais preocupado em guerrear e conquistar territórios do que com cultura, arte e estética. Mas, quando ele entra em contato com a arte grega, fica fascinado por ela. Os romanos acabam por dominar a Grécia, por subjugar a sociedade helênica, mas são dominados pela arte grega, como declara Horácio:

"A Grécia, capturada, capturou o feroz vencedor e as artes introduziu no rústico Lácio..." ${ }^{154}$ (Ep. II, 1, v. 156-157)

\footnotetext{
153 “...tuque / rectius lliacum carmen deducis in actus / quam si proferres ignota indictaque primus." $A$ Arte Poética de Horácio. Tradução de Dante Tringali. São Paulo: Musa, 1994, v. 129-130.

154 "Graecia capta ferum uictorem cepit et artes / intulit agresti Latio ..." Estes versos de Horácio são citados por diversos autores. Aqui, usamos a tradução de VASCONCELLOS, op. cit., p. 13.
} 
O próprio Virgílio, em sua epopéia de exaltação da romanidade, declara, pela voz de Anquises, a consciência que têm os romanos de sua inferioridade na cultura e nas artes, apesar de sua superioridade nas armas:

Outros hão de forjar mais suavemente bronzes que parecem respirar (creio de fato) e do mármore extrairão vultos vivos, melhor defenderão causas e os caminhos do céu descreverão com o compasso e o surgir dos astros dirão; tu, Romano, lembra-te de reger sob teu império os povos (serão estas as tuas artes), impor as condições de paz, poupar os vencidos e debelar os soberbos. (Eneida, VI, v. 847-853) ${ }^{155}$

Toda a literatura, e também a pintura e a escultura, enfim, toda a arte grega foi imitada pelos romanos. Não havia entre eles a idéia de originalidade que temos hoje - antes achavam que inventar algo novo não era motivo para aplausos, além de ser desnecessário, desde que tinham um modelo para imitar que consideravam excelente. Isso não quer dizer que eles não tivessem ou que não fossem capazes de produzir uma literatura própria. Mas, antes do contato com a cultura grega, o que havia em Roma era uma literatura limitada quase que tão somente a assuntos jurídicos e de negócios, sem preocupações poéticas ou estéticas, distante dos parâmetros de perfeição que a arte grega acabou por estabelecer. Assim, quando no século III a.C. se intensifica o contato dos romanos com a cultura grega, o desenvolvimento de uma literatura autônoma é reprimido e vemos o início da helenização cultural de Roma.

Na literatura, Lívio Andronico, escravo grego capturado na tomada de Tarento - importante centro formador de artistas que legou a Roma também o escritor Quinto Ênio -, começa por traduzir e levar à cena uma tragédia e uma comédia gregas, em 240 a.C, para os ludi maximi, em que se comemorava a vitória de Roma sobre

\footnotetext{
${ }^{155}$ Tradução de VASCONCELLOS, op. cit., p. 15. No original, citado por Vasconcellos: "Excudent alii spirantia mollius aera, / credo equidem, uiuos ducent de marmore uoltus, / orabunt causas melius, caelique meatus / describent radio et surgentia sidera dicent; / tu regere imperio populos, Romane, memento / (hae tibi erunt artes), pacique imponere morem, / parcere subiectis et debellare superbos."
} 
Cartago, desprezando a farsa atelana. Ao mesmo tempo, traduz também a Odisséia de Homero. Infelizmente, de sua produção, que parece ter sido ampla, só restaram trinta fragmentos e três títulos. ${ }^{156}$ É bom lembrar que a literatura latina começa por uma preocupação pedagógica: era preciso haver textos em latim para que se pudesse ensinar a ler e escrever, daí as traduções de textos gregos. Depois é que se passou à imitação.

A imitação latina pode ser analisada, hoje, à luz da Arte Poética horaciana, como reelaboração criativa do original grego - lembrando que Plauto e Terêncio escreveram muito antes de haver uma Poética romana. Os romanos tinham a arte grega como exemplo de excelência, mas a imitação, na literatura, deveria ser uma reprodução criativa, não uma reprodução servil ou tradução literal do modelo. Mesmo a tradução implicaria na adaptação do modelo antigo à língua e ao contexto da contemporaneidade romana.

Ao que parece, Terêncio fez mais ou menos isso: traduziu Menandro adaptando-o à sua cultura. Plauto foi mais ousado: brincou com as palavras, fez uso de neologismos, enriqueceu suas comédias com elementos próprios dos mimos, das atelanas, e das manifestações mais populares do teatro, chegando a ser grosseiro para tornar-se mais engraçado. Para definir a obra de Plauto, talvez nem o conceito de aemulatio fosse tão preciso (a imitação com a intenção de superar o modelo). 0 que ele fez, na verdade, foi ser criativo, dentro e além das categorias de inovações definidas por Cairns para a composição genérica.

Podemos adivinhar naquele povo lutador o desejo de igualar e mesmo de superar a grandeza da arte grega. Os romanos haviam, afinal, conquistado o mundo. Ainda assim, a aemulatio parece não ter um sentido de revanche. Aquele que emula continua sendo um grande admirador do modelo, ele só vai tentar emular aquilo que ele considera grandioso, belo - vide a Eneida de Virgílio. É a admiração pelo modelo que leva o artista a tentar "melhorá-lo" e ultrapassá-lo.

$\mathrm{Na}$ verdade, gregos e romanos eram povos de tradição e temperamento muito diferentes e a arte refletia as especificidades de cada um desses povos. No que se refere à comédia de Plauto, o ato criativo vai além da emulação. Plauto fazia parte

${ }^{156}$ Cf. COSTA, Aída. "Introdução". In: PLAUTO. Aulularia. São Paulo: Difusão Européia do Livro, 1967, p. 7. 
de um grupo cômico tradicionalmente romano e tentava situar seu público introduzindo em seu texto versos que traziam ditos, acontecimentos, em suma, qualquer coisa que fosse significativa para eles. Além disso, ele imitou muitas comédias da fase chamada intermediária, que ainda misturava características da Comédia Grega Antiga com outras da Nova, juntando à mistura elementos próprios daquele teatro rústico tão apreciado pelo povo romano. Isso tudo o diferencia muito de Terêncio, um helenista tradicional que rejeitava a maior parte das tradições do teatro cômico romano. ${ }^{157}$

Embora compondo de formas diferentes, Plauto e Terêncio enfrentaram um problema comum na hora de recriar as peças gregas: a quantidade limitada de modelos. Era necessário misturar uma peça com outra - ou outras -, para resultar numa terceira, que terminava por levar o nome daquela que continha o argumento principal. Daí muitas das peças apresentarem dupla intriga. Dessa montagem de textos diversos surgia uma peça nova, inédita. Essa técnica de recriação literária, amplamente usada pelos latinos, foi chamada "contaminação":

Em latim, contaminatio, isto é, processo de criação literária que consistia em imitar um original grego, inserindo-Ihe simultaneamente elementos de diversa proveniência. No caso particular do teatro, a contaminação de dois ou mais modelos gregos dava origem a uma peça, por assim dizer, nova. Não só foi praticada pelos autores dramáticos [...], como está presente em todas as épocas da literatura latina, mesmo em obras de outros gêneros muito diferentes, como é o caso, p. ex., das Bucólicas de Virgílio. A contaminação foi, assim, para os escritores latinos em geral, uma fonte inesgotável de inspiração e, por estranho que pareça, um manancial de originalidade. ${ }^{158}$

Apesar da técnica ser comum entre os autores latinos, Terêncio foi tratado como plagiarius $^{159}$ por fazer uso da contaminatio em sua época. Na verdade, os comediógrafos que o atacavam temiam que pudessem faltar modelos gregos para

\footnotetext{
157 Sobre as diferenças entre Plauto e Terêncio, ver WRIGHT, John. Dancing in chains: the stylistic unity of the Comoedia Palliata. Rome: American Academy, 1974.

158 FONSECA, Carlos Alberto Louro. Prefácio. In: PLAUTO. O Soldado Fanfarrão. Coimbra: Atlântida, 1968, p. 16, nota 19.

${ }^{159}$ No sentido original: aquele que rouba escravos alheios ou rapta pessoas livres para vender como escravos. O termo é uma metáfora elaborada por Marcial $(1,53)$ aplicada no sentido de roubo literário.
} 
suas futuras adaptações. Terêncio defendia-se citando autores como Plauto e Névio, seus predecessores, que sempre fizeram uso da técnica.

Como dissemos anteriormante, a comédia palliata, como recriação da Comédia Nova Grega, pode ser estudada, hoje, a partir das regras estabelecidas por Horácio na Arte Poética. Mas Horácio estabeleceu aqueles princípios para a recriação literária somente no século I a.C. Ele, inclusive, criticava os autores romanos antigos que imitaram sem nenhum critério. Na época de Plauto e Terêncio ainda não havia uma poética que indicasse regras para a criação "em segundo grau". A comédia que eles imitavam eram as de que Aristóteles tratou em sua Poética - embora tenha dedicado muito pouco desse trabalho ao gênero cômico. Regras traçadas por ele para a tragédia, como a das três unidades - lugar, tempo e ação - que dão verossimilhança à fábula, são seguidas pelos autores latinos:

- verossimilhança: o objeto da poesia não é o real, mas o possível - o escritor tem que pensar no que o leitor ou o espectador vai acreditar.

- conveniências: regra para manter o decoro, é a ética da estética. Não poderia haver, por exemplo, cenas de violência, de morte ou de erotismo no palco.

- regra das três unidades: unidade de ação, de lugar e de tempo. Na comédia, em geral, a ação gira em torno de um casal que quer se unir, mas algum obstáculo o impede, então, tudo o que acontece na peça tem que levar ao desenlace dessa situação. Isso é unidade de ação. Tudo acontece no mesmo lugar, ou seja, no mesmo cenário: se um personagem viaja, ele não pode aparecer em outro cenário durante a viagem. Até o seu retorno, ele será somente mencionado. Essa é a unidade de lugar. $E$ tudo o que acontece deve "caber dentro de um período do sol, ou pouco excedê-lo" ( $\mathrm{V}, 24)$, para que haja unidade de tempo. Sem essas regras, perde-se a verossimilhança.

- unidade de tom: a tragédia não pode ter elementos cômicos, assim como a comédia não vai tratar de temas próprios da tragédia - cada assunto em seu lugar. 
Quando Plauto escreve o seu Anfitrião chega a ser proibido de representar a peça por tratar de um deus numa comédia, apresentando-o com defeitos próprios de um homem comum do povo, com a torpeza dos mortais. É então que ele cria o termo "tragicomédia", para escapar à censura genérica imposta pela concepção aristotélica:

A comédia é, como dissemos, imitação de homens inferiores; não, todavia, quanto a toda a espécie de vícios, mas só quanto àquela parte do torpe que é ridículo. $O$ ridículo é apenas certo defeito, torpeza anódina e inocente; que bem demonstra, por exemplo, a máscara cômica, que, sendo feia e disforme, não tem [expressão] de dor. ${ }^{160}$

Neste trecho da Poética, Aristóteles parece referir-se à Comédia Nova Grega - ou à Comédia Intermediária, que não mais tratava de assuntos políticos - e não à Antiga, pois que esta última retratava deuses em suas imperfeições, além de importantes personalidades da vida pública (gente do povo e, até mesmo, animais tinham parte na Comédia Antiga, mas o assunto era sempre, de alguma forma, elevado, de crítica aos que detinham algum tipo de poder, não tratava de questões domésticas). O estagirita diz que a comédia não pode imitar indivíduos particulares, mas a vida do homem comum, e esse é o assunto da Comédia Nova.

\subsection{A Comédia Nova}

Porque os latinos imitaram dos gregos a Comédia Nova - véa - e não a Comédia Antiga? A princípio, podemos pensar que isso ocorreu porque o contato mais intenso dos romanos diretamente com a cultura grega se deu no período helenístico (período que vai da morte de Alexandre, em 323 a.C. até o império de Augusto). E a comédia deste período já é a véa, que é em tudo diferente da antiga. Isso é possível, mas não deve ser a principal razão.

\footnotetext{
${ }^{160}$ ARISTÓTELES, Poética, edição citada, V, 22, grifo nosso.
} 
A Comédia Grega Antiga, cujo único representante que nos foi dado conhecer é Aristófanes, com onze títulos preservados, também chegou a Roma, mas os romanos tinham seus motivos para não aprová-la.

A Comédia Antiga fazia mais ou menos o papel que a imprensa tem hoje. Ela expunha questões políticas, sociais e culturais ligadas à pólis, à cidade. Aristófanes criticava, em suas comédias, a corrupção dos políticos, o abuso de poder e fazia ainda uma espécie de crítica literária, como a que aparece em As Rãs, na disputa entre Ésquilo e Eurípedes, no Hades, pelo "trono de maior dramaturgo morto" ${ }^{161}$ Expunha e criticava qualquer personalidade ou instituição pública. Zombou tanto de Sócrates (As Nuvens) quanto do costume ateniense de levar tudo a julgamento (As Vespas); expôs ao ridículo magistrados e, também, seus rivais de cena. Não poupou nem os deuses. Era uma comédia às vezes tão agressiva, que acabou por ser proibida. Os comediógrafos, não podendo expor instituições ou personalidades públicas ao ridículo, precisaram mudar o alvo da troça.

Assim, temos a hipótese de que as comédias de Aristófanes não serviram como modelo em Roma porque também as autoridades romanas não teriam permitido que se expusessem à troça pública seus personagens ilustres. ${ }^{162}$

Entre a última fase da Comédia Antiga e a Comédia Nova passam-se aproximadamente oitenta anos. Nesse meio tempo, a comédia não fica em estado letárgico mas evolui de forma a ir-se adaptando às novas exigências dos governantes e da sociedade da época. À comédia dessa fase de transição chamamos Comédia Intermediária

$\mathrm{Na}$ transição da comédia Antiga para a Nova, a estreita ligação entre a comédia e a vida política da cidade, que era constante na primeira, vai diminuindo até desaparecer. Na Comédia Intermediária, da qual restam apenas fragmentos de Antífenes e Alexis, ${ }^{163}$ tendo sido proibido aos comediógrafos expor homens públicos, passou-se a não identificar claramente suas personagens, fazendo uma caricatura daqueles que se buscava ridicularizar. Isso, muitas vezes, tornava possível ao

\footnotetext{
${ }^{161}$ Cf. Introdução [sem autoria]. In: ARISTÓFANES. Lisístrata e As Nuvens. São Paulo: Abril Cultural, 1977, p. XIII. (Coleção Teatro Vivo).

${ }^{162}$ Cf. PARATORE, Ettore. História da Literatura Latina. Lisboa: Fundação Calouste Gulbenkian, 1983, p. 30.

${ }^{163}$ Cf. POSSEBON, Fabrício, em seu estudo de HOMERO, Batrocomiomaquia, São Paulo: Humanitas, 2003, p. 64.
} 
público reconhecer de quem se tratava. Então, esta comédia também não foi mais permitida.

Quando chega a Comédia Nova, última manifestação do teatro grego na Antigüidade, os personagens já não são nem caricaturas de uma ou outra personalidade pública, mas tipos comuns da sociedade. Ela já não trata de questões da pólis, de problemas da coletividade, mas de assuntos domésticos, trata da casa e do homem comum, das relações entre marido e mulher, pais e filhos, velhos e jovens, de desencontros amorosos. Na Atenas helenística, formava-se uma pequena burguesia e a Comédia Nova vem retratar os problemas domésticos desta classe. Estes mesmos personagens e seus problemas estarão presentes no palco da palliata latina.

A Comédia Nova apresenta "tipos". O tipo é um personagem-símbolo que reúne em si tudo o que caracteriza no ser humano, em geral, uma determinada deformação do caráter ou mesmo uma virtude levada ao extremo. ${ }^{164}$

Nada diz Aristóteles na Poética sobre esses tipos. Nesta obra, trata da criação artística, de seus princípios, da definição dos gêneros, ocupando-se pouco e superficialmente do gênero cômico. Não se preocupa em definir os personagens cômicos, nem em explicitar quais vícios eles retratam, e nem mesmo qual é a finalidade do gênero. Basta lembrar que quase tudo o que diz da comédia é que ela é "imitação de homens inferiores" ${ }^{165}$ e que imita os homens "piores [...] do que eles ordinariamente são". ${ }^{166}$

O Tractatus Coislinianus, ${ }^{167}$ documento anônimo trazido à luz em 1839 e que se pretendeu fosse a aristotélica Poética II, supostamente perdida, trata mais de como promover o riso na comédia do que de personagens e vícios, embora sugira sua finalidade quando a distingue da tragédia com mais elementos do que o fez Aristóteles:

\footnotetext{
${ }^{164}$ Cf. COSTA, Aída, op. cit., p.30.

${ }^{165}$ Edição citada, V, 22.

166 Ibidem, II, 9.

167 In: JANKO, Richard. Aristotle on comedy: towards a reconstruction of Poetics II. Los Angeles: University of California Press, 1984 e POSSEBON, Fabrício, em seu estudo de HOMERO, Batrocomiomaquia, São Paulo: Humanitas, 2003, de quem utilizamos a tradução.
} 
III A tragédia retira as temerosas afecções da alma, por meio do lamento e do terror, [e porque] quer manter a adequação do temor. E tem como mãe a dor.

IV A comédia é imitação de uma ação risível e excluída de grandeza, perfeita, com enunciado adocicado, separada em cada uma das partes por aspectos. Com atores e não pela narrativa; ela pelo prazer e riso conclui a catarse de tais afecções. ${ }^{168} \mathrm{E}$ tem como mãe o riso.

$[\ldots]$

VIII O zombeteiro quer censurar os erros da alma e do corpo.

O tratado distingue ainda, sem muitos argumentos, a Comédia Nova da Antiga e da Intermediária:

XVIII Da comédia:

- antiga, aquela abundante pelo riso.

- nova, aquela que descuida disso, tendo se inclinado ao grave.

- média, aquela mista de ambas.

Mas o mais próximo que chega da caracterização de personagens é:

XII Os caracteres da comédia são as vulgaridades, as dissimulações e as fanfarronices.

E não vai além disso.

É Teofrasto - que sucedeu Aristóteles no Liceu, dele herdando todas as suas anotações de aula ${ }^{169}$ - quem escreve, depois da morte do estagirita, o opúsculo que é considerado por muitos a complementação da Poética. Na obra intitulada Caracteres, o autor define os tipos observados nas comédias: o avarento, o adulador, o parasita, o misantropo, o vaidoso, o orgulhoso, o fingidor, o fofoqueiro, o trapaceiro, o insatisfeito, o velho que age como um menino, entre outros defeitos de

\footnotetext{
${ }^{168}$ As afecções (os males que afetam a alma) referidas nos itens III e IV são as mesmas, as comuns aos homens, que, conforme se depreende do Tractatus, tanto a tragédia como a comédia, por meios diversos, são capazes de retirar da alma.

169 Cf. FONSECA, Isis Borges B. Introdução. In: ARISTÓTELES. Retórica das Paixões. São Paulo: Martins Fontes, 2000, p. XI.
} 
caráter - ou de éthos. São trinta caracteres, que vão retratar os homens "piores do que ordinariamente são".

Sendo tão ligado a Aristóteles, não nos parece coincidência que os caracteres descritos por Teofrasto se relacionem tão estreitamente aos tipos extremos de conduta a que se refere o filósofo em Ética a Nicômaco - lembrando que de éthos deriva ethiké. Tratando das disposições morais do homem, ou de seu caráter, apresenta os extremos de uma disposição juntamente com seu meio-termo, em que "o meio-termo é louvável e os extremos nem louváveis nem corretos, porém censuráveis". ${ }^{170}$ Assim, para a conduta do homem calmo, que está numa situação intermediária, existem duas condutas extremas e censuráveis, a do irascível e a do apático. A veracidade é o meio termo entre a jactância e a falsa modéstia. Para a espirituosidade, meio-termo quanto à afabilidade no proporcionar divertimento, o excesso é a chocarrice e a falta a rusticidade. Já "o homem que sabe agradar a todos é amável, e o meio-termo é a amabilidade; o que excede os limites é obsequioso se não visa nenhum propósito determinado, e um adulador, se visa ao interesse próprio; e o homem que apresenta a falta, mostrando-se sempre desagradável, é o misantropo." E, assim por diante, quase vemos desfilar a galeria dos caracteres traçados por Teofrasto, que foi preceptor de Menandro, comediógrafo em cujas peças os vemos agir. E mais do que nas peças de Menandro, mais facilmente nas dos comediógrafos latinos, pelo maior número de exemplares que chegaram até nós, podemos ver esses tipos refletidos em quase sua totalidade - 0 adulador, no parasitus; o jactancioso, no miles gloriosus; o irascível no senex iratus, entre tantos outros exemplos.

Também no livro II da Retórica, traçando uma teoria do éthos, Aristóteles trata de alguns tipos de caráter humano, como o do homem jovem, movido pelas paixões; o do velho, que, perdendo as paixões, se torna covarde e pouco confiável; o do homem que está entre esses dois extremos e caracteriza-se pela moderação; o caráter produzido pela riqueza, que é o arrogante e insolente etc. Aí estão mais pistas da origem dos caracteres de Teofrasto.

\footnotetext{
${ }^{170}$ ARISTÓTELES. Ética a Nicômaco. Tradução de Pietro Nassetti. São Paulo: Martin Claret, 2005, II, 1108 a.
} 
Caracteres não chega a ser um tratado. É, na verdade, um conjunto de caricaturas dos pequenos defeitos, ou vícios, dos homens, como observa Garcia:

Não se trata de sisudas reflexões ou de excelentes investigações sobre a condição humana na estrita linha da investigação aristotélica, mas de um bocado de humor sadio e reconfortante sobre os defeitos inerentes a nossa qualidade de seres racionais. ${ }^{171}$

Em Caracteres encontramos uma "mímesis dos defeitos" que podem ser tratados como ridículos na comédia e que deram título a muitas das comédias da época - vide o Misantropo, de Menandro, e o Truculentus, de Plauto. Tanto os tipos como a temática desta comédia foram imitados pelos comediógrafos latinos e, posteriormente, influenciaram a comédia clássica européia e deram origem à comédia de costumes.

Baseada na análise psicológica das personagens, a Comédia Nova expõe essas deformações estampadas na máscara cômica. Em sua origem, o termo grego kharaktēr designava o instrumento que fazia uma gravação, como o da cunhagem de moedas e medalhas, e também a própria gravação: "Um uso metafórico do vocábulo levou-o a significar 'sinal', 'distintivo'. Provavelmente sob esta acepção utilizou-o Teofrasto, quem, talvez, introduziu a novidade de aplicá-lo à alma humana". ${ }^{172}$

A máscara cômica leva a marca de uma forma de ser, é como uma cicatriz da alma que se reflete externamente. O espectador do teatro busca esse encontro consigo mesmo na imitação da vida e de seus caracteres. O palco é o espelho em que se reflete a platéia. Bem expressam as palavras de Mangel: "Para conhecer objetivamente quem somos, devemos nos ver fora de nós mesmos, em algo que contém a nossa imagem, mas não é parte de nós, descobrindo o interno no externo". 173

A Comédia Nova era moralizante, queria mostrar que mesmo uma pessoa com defeitos de caráter poderia, depois de algum acontecimento (por

\footnotetext{
${ }^{171}$ GARCIA, Elisa Ruiz. Introducción. In: TEOFRASTO. Caracteres. Madrid: Editorial Gredos, 1988, p. $22-23$.

172 Ibidem, p. 34.

${ }^{173}$ MANGUEL, Alberto. Lendo imagens. São Paulo: Companhia das Letras, 2001, p. 185.
} 
reconhecimento ou peripécia), tornar-se uma pessoa boa ou, pelo menos, razoável. ${ }^{174}$ Como se viu no último item citado do Tractatus Coislinianus, nela já não abundava o riso. É uma comédia moderada, comedida.

Em Roma, é a palliata que vai cumprir esse papel moral e tratar da vida do cidadão comum, da casa, retratando famílias inteiras, incluindo seus escravos, e um dos membros dessas famílias vai se destacar e ser o protagonista ou o antagonista da ação. Mas todos os personagens intervêm de alguma forma na trama.

\subsection{Temas e tipos da palliata}

Os temas e tipos da palliata latina são os mesmos da véa grega, que traz como tema central, com exceção de Captivi (Plauto), invariavelmente, um desencontro amoroso: um casal enfrenta diversas atribulações no decorrer da ação para no final poder amar-se em paz. A dificuldade do relacionamento entre pai e filho é fundamental no conflito. Ao redor desse núcleo temático transitam outros temas: o do relacionamento entre os homens e suas mulheres, em que os homens apresentam, freqüentemente, misoginia; o tema dos duplos e dos simillimi personagens binários que podem ser irmãos, gêmeos ou não, ter o mesmo nome ou exatamente a mesma aparência, o que causa o qüiproquó. Há também o tema dos filhos perdidos; o do jovem esbanjador e o do velho juvenil; o do retorno inesperado do pai, surpreendendo o filho em delito, entre outros, desenvolvidos em meio a situações hilariantes, quase sempre provocadas por escravos e parasitas.

Existem, quase sempre, duas famílias envolvidas no conflito. Às vezes, uma família mais pobre representa o campo e outra mais rica representa a cidade. Outras vezes encontramos duas famílias vizinhas, cujas casas são de paredes meias, onde vivem dois velhos amigos que querem casar seus filhos e garantir o patrimônio um

\footnotetext{
174 Sobre a catarse na comédia, ver TOUCHARD, Pierre-Aimé, Dioniso: apologia do teatro: seguido de $O$ amador de teatro ou A regra do jogo. São Paulo: Cultrix, 1978. O autor recusa a idéia de catarse cômica. "Na comédia", segundo Touchard, "trata-se sempre de um outro que não sou eu ou de um eu que rejeito. No caso, o único compromisso possível é aquele que supõe a vontade de ruptura." (p. 32) Ver também o citado Tractatus Coislinianus, que trata do riso, meio pelo qual se "conclui a catarse" na comédia.
} 
do outro. Mas é comum que numa terceira casa viva uma meretrix ou uma escrava pertencente a um mercador, o leno, por quem o filho de uma das famílias amigas está apaixonado, o que dificulta o plano dos velhos. Somente em Persa, de Plauto, não aparecem as famílias, que estão fora, mas em suas casas estão os escravos, entre os quais o conflito amoroso se arma.

No cenário, as casas - representadas por portas - dão frente para uma praça onde toda a ação se desenrola. Duas saídas laterais fazem as vezes de ruas: a da direita vai dar no fórum e a da esquerda leva ao campo ou ao porto. Havia ainda uma rua imaginária, angiportus, por trás das casas, que servia como artifício para explicar algumas das entradas de personagens em cena pelas laterais, sem que tivessem saído de casa, ou, ao contrário, sua entrada em cena pela porta de casa, sem que nela tivessem entrado depois da última saída por uma das ruas laterais. Tais aparições seriam inverossímeis sem esta estratégia. No angiportus, que significa beco, desenrolam-se, muitas vezes, as tramóias dos escravos, ou suas desventuras, quando algo dá errado em suas armações. De lá, eles chegam esbaforidos ao centro da cena para contar tais acontecimentos, fazendo imaginar do angiportus um lugar sombrio, como o do cenário do poema 58 de Catulo, onde sua amada Lésbia se prostituía. ${ }^{175}$

Nas comédias gregas e em algumas latinas, aparecia ainda um altar no meio do cenário, que trazia, segundo Berthold, "a estátua do deus em cuja honra a peça era apresentada, e que, nos jogos fúnebres, era substituída pela estátua do falecido. ${ }^{176}$

A concentração do cenário é de grande importância para se conseguir agilidade na movimentação dos personagens. Eles precisam estar sempre se encontrando, depois de desencontros, e temos que imaginar toda uma cidade por detrás da praça, por onde o seruus currens circula sempre às pressas, de acordo com as ordens do patrão. Um personagem está saindo, outro está chegando; um pode estar na praça e não perceber que o outro se aproxima por uma das ruas. A

\footnotetext{
175 "Caeli, Lesbia nostra, Lesbia illa, / illa Lesbia, quam Catullus unam / plus quam se atque suos amauit omnes, / nunc in quadruuiis et angiportis / glubit magnanimi Remi nepotes." ("Célio: nossa Lésbia, aquela Lésbia, / Lésbia, aquela, única que Catulo / amou mais que a si e todos os seus, / agora nos becos e encruzilhadas / descasca os filhos de Remo magnânimo.) O Livro de Catulo. Tradução de João Angelo Oliva Neto, edição citada.

${ }^{176}$ Op. cit., p. 151.
} 
concentração também possibilita uma das situações convencionais, que é a de um personagem escutar o que o outro diz, às vezes em longos monólogos, sem ser percebido, porque o outro chega justamente falando o que aquele precisava saber. Este artificialismo do cenário busca tornar o enredo verossímil e propicia que a ação se desenrole rapidamente.

Neste cenário têm lugar as mais variadas intrigas: um pai de família rica costuma ter negócios no exterior e, por isso, passa muitos períodos fora de casa e da cidade, o que dá chance a seus filhos e escravos de promoverem diversas confusões. Algumas vezes esses pais levam seus filhos consigo na viagem, o que acaba acarretando a perda ou o rapto da criança - a perda de parentes por rapto ou por naufrágio em viagens é bastante comum nos argumentos porque costumava acontecer com freqüência na vida real. A criança, raptada ou perdida, ou vai tornarse escrava, ou vai acabar sendo encontrada e criada por uma família geralmente mais pobre que a sua, para no final haver o reconhecimento e ela voltar ao seio da família e, descobrindo-se rica, poder casar-se com o ser amado, também rico. Quando essa personagem é feminina - a pobre mocinha que se perdeu dos pais ou foi exposta quando criança e que, no final, é reconhecida como cidadã e membro da sociedade ateniense - é quase sempre personagem sem fala, mas em torno da qual o enredo se desenvolve.

Outra situação comum, que ocorre na ausência do pai, é a do filho que esbanja o dinheiro paterno com meretrizes e precisa sempre, com a ajuda de um escravo manhoso, conseguir mais dinheiro para esses gastos. Mas, então, o pai volta e põe um fim à brincadeira, e ainda dá uma lição de moral ao filho desregrado (isso se a peça for de Menandro ou de Terêncio, porque Plauto costuma introduzir o pai na festa do filho). Há, ainda, o motivo do rapaz que precisa conseguir dinheiro para comprar uma escrava por quem está apaixonado, mas o pai Ihe arranja um casamento com a filha de um amigo, que tem um bom dote.

Em meio a essas situações, entram em cena os escravos, os parasitas ou os alcoviteiros com suas artimanhas. São eles que tomam as iniciativas que movem o enredo, são eles que criam as situações cômicas, inventando as mentiras mais estapafúrdias para ludibriar seus velhos patrões em favor dos seus jovens senhores, para bajular fanfarrões em troca de favores, enganando tolos e ingênuos, em geral. 
Dentre os tipos cômicos, estes são os que carregam mais marcas das deformações de caráter que Teofrasto descreveu nos Caracteres.

Os escravos (o tipo seruus, que pode ser currens, callidus, rex ou factotum), que estão, em geral, a serviço do filho da casa, são mentirosos, maledicentes, inconvenientes, fingidos, fofoqueiros. A versão feminina deste tipo é a ancilla, que costuma ter um papel secundário, quando não somente de figuração, na comédia.

O parasita (parasitus) aparece normalmente a serviço do tipo miles gloriosus, o soldado fanfarrão. Ele também tem o papel de inventar mentiras para ludibriar e adular o soldado e viver, assim, às suas custas. É bajulador, servil, fingido e pode também adular outros personagens para conseguir sempre um lugar à mesa, não aparecendo somente ao lado do miles. É quase sempre um tipo comilão - parasitus edax.

O miles gloriosus é "aquele indivíduo que, não passando de um pobre diabo, se julga muito acima dos mortais e que, não raro, é vítima das suas próprias fantasias." ${ }^{177}$ Ele é vaidoso e tem mania de grandeza. O miles vive sendo enganado, tanto pelo seu parasita como pelo alcoviteiro, o leno. É um stultus.

O leno é um tipo semelhante ao escravo e ao parasita, no que diz respeito às artimanhas e mentiras, mas ele é mais mau-caráter. Trafica escravas e citaristas e faz arranjos entre amantes por dinheiro. É, às vezes, tolo - stultus - enquanto se julga muito esperto e se deixa enganar pelos escravos ou parasitas

Outro stultus na comédia é um dos tipos de senex, o velho ingênuo e facilmente ludibriado. É muitas vezes também puerilis, o velho que age como menino.

O senex pode ser ainda iratus, o velho colérico e ranzinza, ou indulgens, o seu oposto, o velho condescendente.

O adulescens é o jovem sempre às turras com o pai ou com o leno por causa da mulher amada. É um tipo quase patético: sofredor, chega mesmo a falar em suicídio.

A Comédia Nova apresentava também o tipo cozinheiro, o cocus, que aparece na comédia de Menandro. É um tipo zombeteiro e espertalhão, que também

${ }^{177}$ FONSECA, Carlos Alberto Louro. Prefácio. In: PLAUTO. O Soldado Fanfarrão. Coimbra: Atlântida, 1968, p. 14. 
entra na história para fazer rir com suas trapalhadas. Na comédia latina, o tipo aparece na Aulularia, de Plauto.

Nos papéis femininos, encontramos a mocinha pobre e virtuosa, a uirgo, que fica em casa esperando que seu pai lhe consiga um dote para que possa se casar. Há ainda aquela que foi raptada e que é pobre ou escrava - pensa-se que não é cidadã ateniense - e, por isso, também não tem como se casar. Em geral, a personagem não tem fala, muitas vezes nem aparece em cena.

Um tipo feminino importante é a meretrix, que também pode ter a função de movimentar o enredo. Tem caráter diferente nos dois autores latinos. Em Plauto é mesquinha e calculista; Terêncio a humaniza.

A alcoviteira (lena) é a mãe proxeneta da meretrix, cuja casa funciona como um bordel. É um tipo raro na comédia latina - encontra-se em Plauto, na Asinaria, em papel relevante, e na Cistellaria, num papel sem importância. Mais comum é o seu correspondente masculino, o leno, que é, na maioria das comédias, o mercador de mulheres.

Um último tipo feminino recorrente é a matrona, a mãe de família, quase sempre às turras com um marido misógino. A matrona aparece poucas vezes, mas é bem caracterizada por Plauto em Casina e Asinaria.

Os tipos são tão importantes no enredo que muitas vezes seus nomes fornecem o título às comédias, como nos casos de Epidicus (nome do seruus), Phormio (nome do parasitus), Bacchides (nome das meretrices), entre outros. A própria denominação do tipo pode ser o título, caso do Miles gloriosus.

Embora sejam os mesmos em Plauto e Terêncio, os tipos e as situações da comédia paliata apresentam características diferentes em cada autor: a meretriz de Terêncio costuma ter uma atitude nobre, o que faz com que o rapaz e seus familiares a tratem com respeito; o mesmo tipo em Plauto pensa somente em diversão e dinheiro. É propriamente terenciano dar um toque de nobreza de alma a esses tipos marcados por defeitos de caráter.

Os temas e tipos das paliatas provinham da comédia grega. Na verdade, os textos eram os mesmos, porém, os comediógrafos latinos costumavam inserir versos em suas adaptações que fizessem menção a alguma coisa significativa do tempo e do local onde a comédia era representada. Em Plauto, isso era bastante comum. Há 
um exemplo do Anfitrião, em que a ação se passa em Tebas, mas o escravo Sósia, no começo da primeira cena do ato I, andando de noite na rua, faz alusão à "polícia noturna" (tresuiri nocturni), que era a guarda de Roma. Tal artifício criava um anacronismo bastante cômico. Esse tipo de adaptação, ao que parece, Terêncio não tinha a mesma destreza para fazer - ou, quem sabe, não tivesse a intenção. Plauto brincava mais com a linguagem e, sob a influência da farsa atelana e do mimo, dava-se mais liberdade para criar. Ele adicionava às suas adaptações das comédias de Menandro, Dífilo ou Demófilo alguma fantasia, trabalhando com mais liberdade do que Terêncio. Este era um helenista fiel ao texto grego, dependente de Menandro, tanto que foi chamado por César de dimidiatus Menander. Embora pareça haver nesse apelido algo de irônico, pois "meio Menandro" pode sugerir uma capacidade artística inferior à do poeta grego, a intenção de César foi de fazer um elogio. $^{178}$

O modo como usavam o prólogo também diferencia os dois comediógrafos. Plauto, nas peças que apresentam prólogo, além de indicar que obras e autores gregos havia adaptado, explicava do que tratava e onde se passava a peça, tudo com muita graça. Terêncio aproveitava o prólogo para defender-se das freqüentes acusações de plágio de que era vítima. Nas peças em que há didascália, esta informa, além de quais foram os modelos gregos, a data ou época de sua representação.

\subsection{Categorias e modos da palliata}

As comédias paliatas podem ser classificadas como "comédia de reconhecimento", “comédia de enganos" e "comédia de caracteres”. Quanto à ação, a comédia pode ser bastante movimentada, e então temos uma fabula motoria; ou ser calma, ter pouca ação, e assim temos uma fabula stataria.

Nas comédias de reconhecimento, algum jovem - homem ou mulher - que foi raptado ou perdido na infância, ou ainda exposto ao nascer, será reconhecido como

178 Cf. MAROUZEAU, J. Introduction. In: TÉRENCE. Andrienne - Eunuque. Paris: Belles Lettres, 1947, p. 46, t. 1. 
filho legítimo de um senhor bem estabelecido e como cidadão ateniense, podendo, assim, casar-se com a pessoa amada. O reconhecimento ocorre quando da descoberta de um anel ou amuleto com que a criança fora presenteada pelas pais, e que guarda consigo. Há também o caso da moça violentada que engravida - a violência acontece à noite, no escuro, e, por isso, um não vê o outro - e o mal-feitor é reconhecido pelo anel que roubara à moça, como na Hecyra, de Terêncio.

A comédia de enganos apresenta muitas peripécias, qüipriquós e o imbróglio é contínuo. Os temas dos simillimi (os muito semelhantes) e da troca de identidade que podem aparecer juntos, como em Bacchides, de Plauto - são os que mais causam equívocos. São bons exemplos desta categoria as comédias plautinas Anfitrião e Os Menecmos.

Nas comédias de caracteres, os tipos são descritos de forma bastante precisa e sua "disposição moral" é acentuada, como em O Misantropo, de Menandro, que traz o caráter a ser descrito já no título, ou em Aulularia, de Plauto, que acentua o caráter do avarento, e na também plautina Trinummus, que privilegia a caracterização do jovem esbanjador.

Por conta das intrigas duplas, resultantes da contaminatio, muitas comédias são ao mesmo tempo de enganos e de reconhecimento. É o caso de Epidicus, de Plauto, em que encontramos personagens binárias, identidades trocadas, a mulher violentada e abandonada grávida, a criança que cresceu longe do pai e que é reconhecida quando adulta. Nesta comédia até o engano é duplo. A multiplicidade de temas e enganos faz crer que esta comédia sofreu a contaminação de vários textos, não de apenas dois. Em Casina, também de Plauto, além de enganos e reconhecimento, há a caracterização acentuada do tipo senex puerilis, o velho que se julga jovem e como jovem quer agir.

As comédias distinguem-se também quanto aos modos da ação, podendo classificar-se como fabula stataria ou fabula motoria.

Cícero compara, em Brutus, 30, a atuação dos oradores à dos atores de teatro, não desmerecendo nenhuma das formas de atuar ou proferir discursos:

Quero, com efeito, que tanto no teatro como no foro sejam elogiados não só aqueles que falam com movimentos rápidos e difíceis, mas também aqueles 
chamados "estáticos", que, quando falam, atuam de forma simples e natural, não afetada. ${ }^{179}$

Classifica-se, assim, como stataria a comédia cuja trama é simples e apresenta pouca movimentação, sendo seus atores chamados "estáticos". Em geral, as comédias de caracteres e as de reconhecimento funcionam deste modo. A obra de Terêncio é tida como exemplo da comédia stataria.

Em oposição à pouca ação da comédia stataria está a comédia motoria. Quase todas as comédias de Plauto cabem neste modo de representação, caracterizando-se pela vivacidade da trama e pelo contínuo movimento da ação.

\section{O modelo italiano}

Na Itália dos já consagrados Dante, Petrarca e Boccaccio, em meio a todas as atribulações que marcam sua história entre o final do século XV e o começo do século XVI - as invasões dos exércitos de Carlos V e Francisco I, as disputas pelo poder, a divisão na Igreja com a reforma proposta por Lutero e, ainda, a peste trazida pelos invasores - floresce um movimento literário que busca resgatar a poética da Antigüidade Clássica, valorizando, porém, a língua vernácula. Entre os artistas que lideraram esta corrente sobressai Ludovico Ariosto, primeiro a imitar os comediógrafos latinos em prosa e no italiano vulgar.

Ferrara, terra natal de Ariosto, foi também um centro cultural que, durante todo o século $X V$, reuniu sábios de todo o mundo ocidental para estudar cultura e filosofia antigas, ${ }^{180}$ promovendo um retorno à cultura pagã e à mitologia greco-latina, valores latentes durante a Idade Média, encobertos pela cultura cristã. A arte profana começava a ter lugar num mundo dominado pelos valores religiosos cristãos, já tão desvirtuados pelos homens.

\footnotetext{
${ }^{179}$ Por falta do texto latino, traduzimos a versão em espanhol: CICERÓN. Bruto. Madrid: Alianza Editorial, 2000.

${ }_{180}$ Cf. GAREFFI, Andréa. Ludovico Ariosto. Firenze: Giunti \& Lisciani Editori, 1995, p. 16. Sobre o teatro de Ariosto, ver também "O teatro renascentista italiano: alguma luz sobre o teatro de Ariosto", artigo de nossa autoria, constante na bibliografia, parcialmente reproduzido neste tópico.
} 
Berço do teatro renascentista europeu, Ferrara viu serem representadas, entre 1486 e 1504, tanto em latim como em versos traduzidos na língua vernácula, várias peças de Plauto e Terêncio. Mas foi Ariosto quem escreveu a primeira comédia regular imitada dos latinos: La Cassaria.

Representada em Ferrara, em março de 1508, La Cassaria inaugura o gênero cômico em prosa. O argumento da comédia é o de dois jovens - adulescentes - que ambicionam duas escravas pertencentes a um leno. Enquanto o velho pai de um deles, que é comerciante, viaja, os rapazes roubam-lhe uma caixa de tecidos confeccionados com fios de ouro e entregam-na ao rufião como penhor pela compra de uma das escravas. Mas o plano, arquitetado por um escravo, falha: a escrava é raptada - no angiportus - enquanto era encaminhada ao amante e, o que é pior, o pai do rapaz volta inesperadamente de viagem. O leno é, então, acusado de furtar a caixa, mas o velho descobre a trama do escravo e manda castigá-lo. Outro escravo assume a tarefa de conseguir dinheiro para pagar as moças ao rufião e, desta vez, obtém êxito: engana o velho e tira-lhe o dinheiro necessário; a escrava raptada reaparece e a comédia tem um final feliz para todos, como soem ser os finais de todas as comédias.

Não há um texto latino específico na base de La Cassaria, mas uma mistura de vários motivos provenientes de comédias diversas: "o motivo da caixa está em Poenulus; o do retorno imprevisto do pai encontra-se na Mostellaria, no Phormio e no Trinummus; o do dinheiro tirado do velho está nas Bacchides."

Em La Cassaria, Ariosto amplia a idéia de contaminatio e, baseando seu argumento não só em temas e motivos ${ }^{182}$ de várias comédias latinas, mas também nos da literatura italiana, principalmente tomados às novelas do Decamerão, de Boccaccio, ele constrói sua comédia como montagem de fragmentos, como "mosaico de citações" provenientes de dezoito peças de Plauto e de todas as seis

\footnotetext{
${ }^{181}$ GAREFFI, op. cit., p. 75.

182 Os termos "tema" e "motivo" aparecem nos vários trabalhos que estudamos para designar, muitas vezes, a mesma coisa. Para não haver dúvidas quanto ao que designa cada um deles neste trabalho, apresentamos, resumidamente, as definições que deles encontramos em dicionários de teatro e de termos literários, constantes em nossa bibliografia: Tema é um elemento estrutural, organizador do texto, mas pode haver tema central e temas secundários num mesmo texto. Motivos são elementos menores e mais numerosos, são temas recorrentes, situações que se repetem. $O$ tema, mesmo que central, não deixa de ser um motivo, posto que faz mover a ação.
} 
de Terêncio. Segundo pesquisa de Angela Casella, ${ }^{183}$ Ariosto utilizou na composição de La Cassaria, entre as peças de Plauto, 14 citações de Pseudolus, oito de Bacchides, sete de Asinaria, sete de Epidicus, sete de Poenulus, cinco de Mercator, cinco de Rudens, quatro de Persa, três de Miles Gloriosus, três de Trinummus, duas de Captivi, duas de Cistellaria, duas de Curculio, duas de Stichus, uma de Aulularia, uma de Casina e uma de Truculentus; das peças de Terêncio, extraiu dez citações de Phormio, sete de Andria, sete de Heautontimorumenos, três de Adelphoe, três de Hecyra e uma de Eunuchus.

São cento e cinco citações somente das comédias latinas e, ainda assim, Ariosto apresenta sua peça como "nova", do mesmo modo que os latinos apresentavam as suas:

Nova comedia v'appresento piena

Di varii giochi che né mai latine

Né greche lingue recitarno in scena.

184

Parece-nos oportuno reproduzir a nota explicativa de Stefani sobre o fato de Ariosto apresentar sua comédia como nova: "Nova: segundo alguns, nenhuma vez representada, mas, na verdade, original em relação aos modelos, porque não há na base da fabula um texto específico que tenha sido recitado na Antigüidade e por isso nunca vista antes." 185

Lembramos que a questão da "originalidade" da obra não pode, no caso dos poetas latinos e classicistas, ser tratada com o mesmo juízo que estabelece o plágio em épocas atuais. A contaminatio era uma técnica aceita e praticada intencionalmente que permitia ao poeta exercitar criativamente a arte de imitar; tinha-se o processo alusivo como elemento estrutural do texto. A combinação de

\footnotetext{
${ }^{183}$ Citada por Gareffi, op. cit., p. 75.

${ }^{184}$ Prólogo de La Cassaria. ARIOSTO. L. Commedie: La Cassaria - I Suppositi, a cura di Luigina Stefani. Milano: Mursia, 1997, p. 81. "Nova comédia vos apresento cheia de vários jogos [verbais], que nem a língua latina nem a grega jamais recitaram em cena." O prólogo desta comédia é escrito em versos, enquanto o restante da comédia foi composto em prosa.

${ }^{185}$ La Cassaria, edição citada, nota 1, p. 81: "Nova: secondo alcuni mai rappresentata altre volte; ma in realtà: originale rispetto ai modelli perché non ha alla base della fabula alcun texto specifico recitato nell'antichità e perciò mai vista prima."
} 
peças ou de trechos diversos de várias delas produzia, sim, uma obra nova e, do ponto de vista da época, "original", posto que se tornava também modelo para outros autores. Além disso, o que a comédia clássica do Renascimento retoma, principalmente, são as convenções e as fórmulas, os temas e os tipos, enfim, os lugares-comuns da comédia latina de Plauto e Terêncio. Aludir, citando, condensando ou parafraseando textos antigos, era mais uma convenção que inseria o autor renascentista na tradição clássica.

O problema é que o poeta italiano não declara que peças vai parafrasear ou citar, a quais vai aludir - como também não declarariam os portugueses depois, seguindo este modelo -, o que torna mais difícil a tarefa do pesquisador de buscar suas fontes. Ele indica apenas que vai imitar os autores latinos, como se bastasse saber que aquele era um exercício literário de recomposição. O sucesso da peça dependia do talento do poeta ao arranjar e combinar as diversas alusões, ou seja, a peça nova não poderia parecer um vaso remendado, mas sim uma pintura completa e sem rachaduras. $E$, naturalmente, somente aqueles que conhecessem profundamente os textos latinos aos quais o texto novo alude poderiam se deleitar no reconhecimento.

Ariosto escreveu ainda mais quatro comédias: I Suppositi (1509); II Negromante (terminada em 1520); Gli Studenti (na qual deve ter trabalhado entre 1520 e 1524, mas que deixou inacabada); e La Lena, sua obra-prima dentro do gênero cômico, representada em 1528. Todas, portanto, possíveis modelos para as comédias de Sá de Miranda.

$\mathrm{Na}$ primeira comédia, o poeta ainda está treinando, tentando participar de uma tradição, mas La Cassaria já é uma peça de grande mérito no que toca à criatividade por trazer um argumento novo. Além disso, tem todo um trabalho de lima, de aperfeiçoamento formal e de erudição que tem que ser valorizado. Mas seu grande mérito está em ser iniciadora - como para Portugal foi a primeira comédia de Sá de Miranda - e em inserir a prosa e o vernáculo no contexto clássico:

Ché tale impresa non li par suggetto

De li moderni ingegni e solo estima Quel che li antiqui han detto esser perfetto. 
È ver che né volgar prosa né rima

Ha paragon con prose antique o versi, Né pari è l'eloquenzia a quella prima;

La vulgar lingua di latino mista

È barbara e mal culta, ma con giochi

Si può far una fabula men trista.

Ariosto tinha consciência, apesar da falsa modéstia demonstrada neste trecho do prólogo, de ser o "inventor" de um novo gênero, de ser o primeiro a recriar a comédia dos antigos em prosa e língua vernácula, recheando-a de jogos lingüísticos inteligentes, e de fazê-lo de forma diferente da dos latinos: sem um texto base, criando uma fabula inédita, construída a partir de versos dos mais variados textos, como quem monta um quebra-cabeças.

A partir da segunda comédia, I Suppositi, ele começa a promover inovações à fórmula anterior. Além de trazer a ação para Ferrara - a ação da primeira transcorria na Grécia, como a das latinas - e de incluir a autocitação, ele cria um novo tipo cômico, o "doutor", a ironizar os sábios de ocasião. Acreditamos que Ariosto tenha se inspirado no miles gloriosus, o soldado fanfarrão, para criar o seu "doutor". O miles era um tipo da comédia latina que costumava se vangloriar de sua coragem, de suas façanhas na guerra, de sua beleza e sensualidade, e aparecia freqüentemente acompanhado de um tipo parasita, que o adulava para conseguir um lugar à mesa. Naturalmente, ele não era portador de tais qualidades, ao contrário, era covarde, feio e incapaz de atrair a atenção das mulheres. Assim é o "doutor", que se vangloria agora de sua intelectualidade, não perdendo nenhuma oportunidade de fazer uma citação em latim e de demonstrar sua pseudo-erudição. Apesar de ser já entrado em anos, julga-se atraente e quer tomar uma mulher jovem por esposa.

\footnotetext{
${ }^{186}$ Continuação do prólogo de La Cassaria, edição citada: "Porque tal empresa [a nova comédia] não parece assunto dos engenhos modernos [parece assunto dos antigos] e só estima aquele que os antigos disseram ser perfeito. É verdade que nem prosa vulgar, nem rima tem comparação com prosas ou versos antigos, nem a eloquüência é par para aquela primeira; [...] A língua vulgar, misturada de latim, é bárbara e pouco culta, mas com jogos se pode fazer uma comédia menos ruim."
} 
Este tipo remete ainda aos sábios ironizados por Erasmo no Elogio da Loucura, que é da mesma época (1509), e será retomado por Maquiavel, na Mandrágora, por Sá de Miranda, n'Os Estrangeiros, e por tantos outros autores posteriormente - para citar só alguns portugueses, ele é retomado por Dom João da Câmara, com o seu Porfírio de Os Velhos, e por Miguel Rovisco, que o reaproveita na adaptação que fez da peça de D. João da Câmara, Os velhos e Mefistófoles, com o personagem Herculano. Lembremos ainda do tipo "Dottore de Bolonha" da Commedia dell'Arte, que representa o sujeito pedante, o letrado de discurso vazio como o tipo de Ariosto. Não podemos afirmar que o "dottore" tenha sido inspirado no "doutor" de I Suppositi, mas isso parece possível, já que a origem da Commedia dell'Arte está na passagem do teatro erudito e amador do começo do século XVI para o teatro profissional e não literário, que acabaria por firmar-se no século XVIII. Berthold explica:

Quando o conceito de Commedia dell'arte surgiu na Itália no começo do século XVI, inicialmente significava não mais que uma delimitação em face do teatro literário culto, a commedia erudita. Os atores dell'arte eram, no sentido original da palavra, artesãos de sua arte, a do teatro. Foram, ao contrário dos grupos amadores acadêmicos, os primeiros atores profissionais. ${ }^{187}$

A Commedia dell'Arte nasce, assim, em contraposição à comédia erudita, como resposta popular ao academicismo do teatro clássico. Seus tipos assemelhamse aos caracteres traçados por Teofrasto, mas, com exceção do "doutor", também estavam presentes na comédia atelana, que era improvisada, sem texto prévio, como a dell'arte. Sua primeira apresentação deu-se em Veneza, no carnaval de 1520. O "doutor" de Ariosto data de 1509 e é, portanto, um paradigma possível para o "Dottore de Bolonha".

I Suppositi, que foi modelo também para Shakespeare ( $A$ megera domada), traz no argumento o caso do jovem Erostrato, um siciliano que vai a Ferrara, na companhia de seu escravo Dulippo, a fim de estudar. Ao chegar, conhece Polinesta, filha do velho Damone, por quem se apaixona perdidamente, mas a moça está prometida em casamento ao velho jurista Cleandro. O rapaz troca, então, roupas e

\footnotetext{
${ }^{187}$ Op. cit., p. 353.
} 
identidade com seu escravo e vai servir na casa da moça, encontrando-se com ela todas as noites, às escondidas, sob a proteção da ama. O falso Erostrato (Dulippo), instalado na casa vizinha, oferece ao pai de Polinesta um dote superior ao oferecido por Cleandro pela mão da moça e, enganando um estrangeiro - previnindo-o de que seu povo não é bem vindo em Ferrara - faz com que ele se passe por Filogono, o pai de Erostrato, para convencer Damone a renunciar ao oferecimento de Cleandro. Porém, o namoro de Polinesta e o falso Dulippo é descoberto e Damone manda prender o rapaz. Neste momento, chega a Ferrara o verdadeiro Filogono à procura do filho. O maior qüiproquó tem lugar por conta da troca de identidades entre o estrangeiro e o pai verdadeiro do rapaz, tramada por Dulippo, mas é isso o que leva ao desenlace, quando o engano não mais se sustenta e a verdade é revelada. Por fim, todos concordam com o casamento entre Polinesta e o verdadeiro Erostrato, sendo preterido o doutor Cleandro - final feliz que inclui o típico encerramento das comédias latinas: Valete et plaudite.

Do tema da troca de identidades entre o jovem estudante estrangeiro e seu escravo - para que o jovem pudesse conviver com a amada em sua casa, enquanto o escravo, de fora, promovia os enganos que tornavam o romance possível aproveitou-se o bardo inglês em $A$ megera domada. No motivo do velho jurista que, julgando-se atraente, disputa o amor de uma bela jovem com um rapaz, Sá de Miranda baseou Os Estrangeiros. Como se vê, I Suppositi aparece, ao longo do Classicismo, como paradigma literário tanto quanto o foram as comédias latinas.

O tema da troca de identidades, topos da comédia latina, pode ser verificado no Eunuchus, de Terêncio, e em Menaechmi, Casina, Amphitryo e Captivi, de Plauto. Mas, diferentemente do que fez em sua primeira comédia, nesta Ariosto informa no prólogo quais peças dos antigos seguiu:

Qui tra l'altre supposizioni el servo per lo libero et el libero per lo servo si suppone. E vi confessa in questo l'Autore avere e Plauto e Terenzio seguitato, de li quali l'un fece Cherea per Doro, e l'altro Filocrate per Tindaro, e Tindaro per Filocrate, l'uno ne lo Eunuco, l'altro ne li Captivi ... ${ }^{188}$

\footnotetext{
${ }^{188}$ ARIOSTO, L. Commedie: La Cassaria - I Suppositi, edição citada, p. 153-154. "Aqui, entre outras trocas, o escravo pelo livre e o livre pelo escravo se substituem. E nisto confessa o autor haver tanto Plauto como Terêncio seguido, dos quais um fez passar Querea por Doro e o outro, Filócrates por Tíndaro e Tíndaro por Filócrates, um no Eunuco, o outro nos Cativos ..."
} 
Como em La Cassaria, a técnica de composição utilizada pelo autor em I Suppositi também não é a da contaminação de dois modelos - embora sua fábula tenha por base as duas comédias anunciadas no prólogo - mas a da montagem de fragmentos provenientes de fontes diversas: alusões a versos plautinos e terencianos, a trechos do Decamerão, de Boccaccio, além da autocitação. As notas à edição de que dispomos indicam as seguintes alusões: Mercator, II, 2, 289-298 e Decamerão, VIII, 9, 45 (Supp. I, 2); La Cassaria, IV, 9 (autotextualidade, alusão a situação - Supp. II, 2); Casina, II, 8, 466 (Supp. II, 3); Amphitruo, IV, 3, 1021 e ss. e Trinummus, IV, 2, 843 e ss. (Supp. IV, 4 e IV, 5); Captivi, IV, 2, 826-827 (Supp., V, 2); alusões a situações de Captivi, IV, 2, Persa, I, 3 e Eunuchus, II, 2 (Supp., V, 4); Eunuchus, V, 1 (topos - Supp., V, 2); Aulularia, II, 6, 250-251 (Supp., V, 6).

Também os nomes próprios de personagens vêm do modelo latino: Damone é um senex de Rudens; Carino, verdadeiro nome de Dulippo, é nome comum entre os adulescentes apaixonados (Mercator, Pseudolus, Andria); Sofronia (Sophrona), nome da mãe de Dulippo, apenas referida na peça, aparece em Eunuchus e Phormio. Outros mecanismos geradores de comicidade próprios da composição de peças latinas, já utilizados em La Cassaria, mantêm-se nesta comédia, como a enumeratio (“...né per compassione o pensione o prece o prezzo te ne arei parlato...") e os jogos verbais (semânticos e fônicos).

Com II Negromante, escrita originalmente em versos entre 1509 e 1520, o poeta aproxima-se mais da sua realidade cotidiana. As alusões aos antigos agora se restringem praticamente à forma, o conteúdo é quase todo atual. Os temas do casamento não consumado e do casamento em segredo provêm, respectivamente, da Hecyra e do Phormio, ambas de Terêncio. Mas o personagem principal, que dá titulo à comédia, é colhido entre situações do cotidiano do poeta.

A crítica à sociedade, que nas duas primeiras peças era tímida e velada, agora é mais aberta. Ariosto satiriza uma sociedade que toma como conselheiros os astrólogos e nigromantes e que se deixa enganar por curandeirices. O motivo não é original, já fora utilizado por Bibbiena na Calandria, que é de 1513 (comédia que cedeu a II Negromante também o motivo do caixão onde vai escondido um homem e que provém originalmente do Decamerão, II, 9) e por Maquiavel, com seu falso 
médico, na Mandrágora, de 1518. O ineditismo fica por conta de uma situação nova. Ariosto não apresenta um enganador e um grupo de enganados, mas uma situação em que todos enganam a todos e, ao mesmo tempo, todos são enganados. Não há um culpado único a ser punido, todos padecem das mesmas fraquezas próprias do ser humano. "O Nigromante é antes de tudo uma vasta sátira contra a necedade humana, vista através do prisma da compreensão", resume Salazar. ${ }^{189}$

Em La Lena, Ariosto volta a buscar inspiração no passado. A comédia tem por base a Asinaria de Plauto, que introduz a versão feminina do leno, tipo cômico da comédia latina que representa o sempre vil mercador de escravas. $\mathrm{Na}$ versão feminina, o tipo representa a alcoviteira e aparece somente em duas das comédias plautinas, na Asinaria e na Cistellaria, e, em ambas, a lena faz a mãe que vende os "favores" da filha, a meretrix, tipo feminino de maior importância na comédia antiga. Mas é a lena da Asinaria, única de papel relevante, o arquétipo da alcoviteira, que terá seu mais famoso exemplar na Celestina, de Fernando de Rojas (1499). A lena de Ariosto, que se caracteriza também como a meretrix da comédia latina, tem um pouco das duas: como a Celestina, ela não é a mãe daquela a quem pretende corromper, mas baseia-se na Cleéreta, mãe da meretrix em Plauto, o que se pode depreender de suas falas parafraseadas por Ariosto - na verdade, todo o diálogo entre a Lena e o jovem, entre outros diálogos e situações da peça, são parafraseados da Asinaria. Ariosto aproveita-se do tema antigo para criticar toda a sua sociedade, do povo às instituições do poder que se deixam corromper pela força do dinheiro.

Talvez porque Ariosto evitasse o confronto direto, no plano particular, e direcionasse sua crítica à sociedade em geral, suas comédias não tenham angariado a simpatia da crítica, sempre muito ocupada em desvendar o mistério do conteúdo do Orlando Furioso. Talvez porque Maquiavel, na Mandrágora, assumisse, em tom de farsa aristofânica, uma crítica escancarada à corrupção do clero e à venda de indulgências promovida pela Igreja, esta sua comédia tenha sido considerada pela crítica a obra-prima do teatro renascentista. Mas o fato é que o homem de teatro Ariosto foi mal compreendido e suas peças mal interpretadas.

189 SALAZAR, Maria Tereza N. Introducción. In: ARIOSTO. El Nigromante. Barcelona: BOSCH, Casa Editorial, 1976, p. 65. 
Embora apontado como apolítico, "spirito altrettanto areligioso quanto afilosofico", 190 em suma, indiferente, não é este o homem que encontramos ao entrar em seus textos. O que observamos é que a genialidade do poeta está, justamente, na sua perspicácia enquanto observador de sua civilização, de seus semelhantes, de tudo que acontece à sua volta. Ele se apropria de tudo que tem à disposição: de seus predecessores literários (dos mais antigos aos mais próximos), das crises que agitam sua época (religiosa, política, cultural), de todo o debate sobre a loucura e a razão (A Nau dos Loucos, o Elogio da Loucura) e lança sua crítica, equilibradamente, contra toda uma civilização, sem a necessidade de ser agressivo. Sua ironia não é mordaz, é sutil e discreta.

Ariosto foi um verdadeiro homem de teatro, antes de ser o poeta épico autor de uma das mais belas jóias do Renascimento, o Orlando Furioso, pelo qual conquistou a fama, e sua importância para a história do teatro é fundamental.

Seu primeiro envolvimento com as comédias latinas dá-se em 1493, quando Ihe foi pedido que preparasse e levasse à cena algumas comédias para uma comemoração no palácio ducal de Ferrara. Depois disso, Ariosto passa a traduzir para o vernáculo e levar à cena na língua vulgar, produzindo e dirigindo, as comédias que antes eram representadas na língua de origem, o latim.

Com a composição de La Cassaria, Ariosto começa a reconstruir o teatro, reelaborando de forma criativa a comédia latina, para inaugurar uma nova fase do teatro mundial: "É a primeira comédia de Ariosto e é também a primeira comédia regular do período renascentista, é o arquétipo sobre o qual se modelará todo o teatro cômico que deverá vir, obras-primas inclusive", lembra Gareffi. ${ }^{191}$

Quanto às comédias de Maquiavel e Bibbiena, têm como modelo principalmente Ariosto, no que toca à composição em prosa e aos temas da atualidade, sendo que o primeiro é um crítico ferrenho da corrupção na Igreja, sem deixar de criticar a sociedade, e o segundo, um crítico mais a par com Ariosto no que diz respeito às práticas supersticiosas. Ambos fazem refletir em suas peças a vida

\footnotetext{
${ }^{190}$ CROCE, B. Ludovico Ariosto. In: La Crítica - Rivista di lettratura, storia e filososfia, diretta da B. Croce, volume XV. Bari: Gius. Laterza 7 Figli, editori, 1917, p. 90.

${ }^{191}$ GAREFFI, op. cit., p. 73-74. "È la prima commedia di Ariosto, ed è anche la prima commedia regolata della stagione rinascimentale, è l'archetipo sul quale si modellerà tutto il teatro comico che dovrà venire, capolavori inclusi."
} 
local e contemporânea. Os temas emprestados à comédia latina só muito levemente remetem a algum modelo em particular, são mais gerais e encontrados em comédias variadas. Na Mandrágora, Maquiavel retoma, principalmente, os tipos cômicos: "Um amante mesquinho, um doutor pouco astuto, [...] um parasita favorito da manha,"192 a eles acrescentando um tipo novo, "um frade de má vida" que dá o mote para a crítica à Igreja e ao clero. O motivo mais notável da Calândria, de Bibbiena, é o que evoca o Decamerão, II, 9, como já mencionamos, mas esta é também uma contaminação das comédias plautinas Menaechmi e Casina, pelos motivos da separação entre irmãos na infância por rapto e da troca de identidades entre homem e mulher, respectivamente.

Outro modelo sincrônico, para italianos e portugueses, que por ser único não receberá um tópico próprio, é a tragicomédia espanhola $A$ Celestina, de 1499, cuja protagonista, que dá título à obra, se tornou paradigma do tipo alcoviteira para as comédias modernas - não esquecendo que a Cleéreta de Plauto foi a protoalcoviteira.

Traços da lena Celestina podem ser reconhecidos tanto na personagem Lena de Ariosto, como no Bristo, o alcoviteiro homossexual da comédia de António Ferreira. Mas é uma peça que não segue regras e não se encaixa na fôrma clássica. Talvez por isso não tenha contribuído com muito mais do que o perfil de um tipo cômico para as composições nos moldes clássicos da época.

\footnotetext{
${ }^{192}$ No prólogo da Mandrágora, tradução de Gino Saviotti. ARIOSTO; MAQUIAVEL; BIBBIENA. Obras primas do teatro italiano. Lisboa: Cosmos, 1945.
} 


\section{Sá de Miranda \\ e o diálogo intertextual com seus paradigmas}

\section{Introdução}

Francisco de Sá de Miranda nasceu em Coimbra, em 1487, ${ }^{193}$ e morreu na sua Quinta da Tapada, no Minho, em 1558. Filho do cônego Gonçalo Mendes de Sá e de D. Inês de Melo, estudou as línguas grega e latina na adolescência e, depois, Direito na Universidade em Lisboa, possivelmente mais por vontade do pai do que por vocação. Rodrigues Lapa, no prefácio das Obras Completas de Sá de Miranda, considera: "Homem de altas visões, instruído na leitura dos antigos, trazia já em mente uma nova idea da arte." ${ }^{194}$ Por conta dessa "nova idéia da arte", ele abandona o direito, após a morte do pai - que, segundo consta, impedia sua entrega total à literatura - indo, em 1521, ${ }^{195}$ tomar os ares da modernidade na Itália e "beber [...] as novas inspirações da Renascença, que em Portugal apenas se pressentiam." 196

Sá de Miranda participa de dois períodos da literatura portuguesa. O período anterior à sua viagem é uma fase em que ele ainda aplicava somente as velhas fôrmas poéticas: escreveu cantigas, vilancetes, trovas, que foram reunidas no Cancioneiro Geral de Garcia de Resende. A partir de sua volta da Itália, torna-se responsável pela reforma literária em Portugal, pela introdução da nova métrica - a

\footnotetext{
${ }^{193}$ Conforme a bula do papa Júlio II, de 10 de fevereiro de 1509, "concedendo a Francisco de Sá, bacharel em Decretos, de 22 anos de idade, a igreja de S. Julião de Mouronho, da diocese de Coimbra, a que resignara João Rodrigues". In: Chartularium Universitatis Portugalensis (1288-1536). Editado por Francisco da Gama Caeiro, António Domingues de Sousa Costa e outros. Lisboa: Instituto Nacional de Investigação Científica, vol. 10, 1991-9, p. 386. Grifos nossos. A nota importa porque quase todos os estudiosos da obra de Sá de Miranda dão o ano de 1481 como o de seu nascimento.

${ }^{194}$ RODRIGUES LAPA, M. Prefácio. In: SÁ DE MIRANDA, Francisco de. Obras Completas. 2. ed. Lisboa: Livraria Sá da Costa, 1942, p. IX, v. I. (Coleção de Clássicos Sá da Costa).

${ }^{195}$ Há controvérsias quanto à data de sua partida para a Itália, mas aceitamos a mais provável, 1521.

${ }^{196}$ RODRIGUES LAPA, loc. cit.
} 
redondilha é substituída pelos versos decassílabos -, das novas formas poéticas apresenta o modelo petrarquiano -, do ideal de arte do Renascimento - a retomada dos modelos da Antigüidade Clássica e sua "imitação criativa" - e do teatro chamado erudito, por basear seu texto na alusão a textos consagrados. Além das duas comédias, Sá de Miranda escreveu também uma tragédia, Cleópatra, da qual restam apenas poucos versos.

Embora não abandonasse de todo as formas da tradição medieval - na poesia, ainda vai misturar o velho com o novo -, o que marca o início do Classicismo em Portugal é justamente o seu regresso da Itália, em 1527, apresentando esse novo ideal poético juntamente com um exemplar do novo gênero cômico, em língua portuguesa, a comédia em prosa Os Estrangeiros.

"Miranda seduzido pelo renascimento italiano não se limitou à reforma lírica que após o seu regresso a Portugal tratou de implantar por si e pelos seus admiradores. Trouxe também do país clássico o gôsto pelo teatro e assim quis fazer conhecer cá um pouco do que lá tinha visto." ${ }^{197}$ Estas palavras de Mendes dos Remédios fazem parecer que não havia teatro em Portugal antes da volta de Sá de Miranda, ou que os portugueses não tivessem até então desenvolvido o gosto por esta arte, quando é sabido que, à época, já se formara uma tradição teatral com Gil Vicente e seus autos e farsas. O que o poeta deve ter tentado foi promover uma renovação no gosto pelo teatro, apresentando ao público português a novidade dos palcos italianos.

O fato de suas comédias terem sido compostas em prosa, na língua vernácula e representarem um momento histórico de um passado muito recente, além de criticar situações que vinham ocorrendo no presente, indica que Sá de Miranda não buscou inspiração diretamente nos clássicos latinos, mas os imitou a partir do modelo italiano, especialmente o das comédias de Ludovico Ariosto, primeiro poeta do Renascimento a adaptar o modelo das comédias de Plauto e Terêncio, originalmente compostas em verso, à prosa, à língua e à cultura italianas. Divididas em cinco atos, como sugere Horácio, seguindo as regras aristotélicas das três unidades - ação, lugar e tempo - e apresentando tipos e temas, assim como

${ }^{197}$ REMÉDIOS, J. Mendes dos. As comédias de Sá de Miranda. Revista da Universidade de Coimbra. Vol. XI. Coimbra: Imprensa da Universidade, p. 1068. 
fórmulas e convenções próprios da comédia latina, as peças receberam da pena do poeta do Orlando Furioso a mesma carga de crítica à sociedade da época e às suas instituições que se pode observar no grande épico e em suas Sátiras e que outros poetas coetâneos reproduziriam em seguida, nomeadamente, Maquiavel e Bibbiena, ambos também exercendo influência na composição das peças de Sá de Miranda.

As primeiras décadas do século XVI configuram um momento de experiências, uma fase do renascimento italiano muito mais criativa - entre outras razões, porque ainda não se postulara um conjunto de princípios para a recriação poética - do que imitativa, como se tornaria a fase posterior, na segunda metade do século, o que é possível observar mesmo na comparação entre as recriações de outros gêneros poéticos, como as épicas dos italianos Ariosto e Torquato Tasso (1544-1595), o primeiro, permitindo à imaginação que fluísse solta, no seu Orlando: entre fórmulas da épica da Antigüidade e fábulas medievais, contos cavaleirescos, elementos do maravilhoso e do universo cristão (há até uma viagem à lua, que tem como guia o Evangelista), Ariosto constrói - sem a censura imposta pela Igreja, que viria, pouco depois, tolher a criatividade dos artistas, nem a imposição de regras para a composição - uma narrativa fantástica; Tasso, o "Homero italiano", assumindo de todo a imitação sob normas rígidas, engessado num modelo (ele próprio compôs três livros sobre poética, os Discursi dell'arte poetica e in particolare del poema eroico, de 1566) escreve num momento em que o poeta perdia a "autonomia do poético". A mesma comparação demonstra essa diferença entre o Orlando Furioso e Os Lusíadas, de Camões (não havendo na literatura portuguesa um modelo de épica do primeiro período para comparar). O tradutor do Orlando para a língua portuguesa, Pedro Garcez Ghirardi, explica as relações poéticas entre essas duas fases:

Sobre as relações entre Camões e Ariosto muito tem sido escrito [...]. Como se sabe, Camões, já nas primeiras estrofes de seu poema evoca os heróis de Ariosto, mas parece estabelecer com o Orlando Furioso uma relação ao mesmo tempo de aproximação (no plano expressivo) e de afastamento (no plano da liberdade fantástica). Isso se explica se lembrarmos que o Orlando Furioso aparece em 1516 (a edição definitiva é de 1532), ainda no início do Renascimento, portanto. E aparece como afirmação da autonomia do poético (como o Príncipe de Maquiavel, no mesmo período, afirma a autonomia do político). Entretanto, com o refluxo da segunda metade do século XVI (basta 
aqui lembrar a reforma tridentina e a cristalização de uma retórica normativa), a fantasia poética se vê mais vigiada pela ortodoxia religiosa e retórica. Daí a complexa relação entre um grande poeta do pleno Renascimento, como Ariosto, e grandes poetas do fim do Renascimento, como Camões e Tasso. ${ }^{198}$

Tendo Sá de Miranda presenciado justamente aquele primeiro momento da retomada dos clássicos antigos na Itália, pareceu-nos provável que características daquele período de maior liberdade tivessem influenciado o processo de composição de suas comédias e sob esta perspectiva baseamos nossa análise.

Iniciador de um movimento, Sá de Miranda ousou inovar ao invadir um território que era de domínio das farsas e autos de Gil Vicente, tão ao gosto português. É possível afirmar que Sá de Miranda foi um revolucionário ao introduzir um teatro que reflete o novo ideal poético da época, baseado na renascente cultura greco-latina, cultura pagã, num país marcado pelo fanatismo religioso cristão e, ainda, acrescentar ao nosso encômio que Sá de Miranda foi audacioso ao lançar em suas comédias duras críticas à ociosidade e corrupção do clero e à degradação dos costumes de sua época, ainda que o fizesse de forma indireta e sob a proteção dos príncipes portugueses, que aplaudiram sua iniciativa de inserir a literatura portuguesa no contexto da nova era - note-se que a cena de suas comédias não se passa em Portugal e que o poeta direciona sua crítica a Roma e aos italianos. A esse respeito, pondera Thomas Earle:

Seria improvável que membros da família real tivessem tolerado o humor de Sá de Miranda a menos que eles soubessem que este não se dirigia a eles nem às instituições que eles representavam. Isto se aplica particularmente ao Infante Henrique, cardeal e inquisidor-geral, que era um amante do teatro e um admirador e patrono do trabalho de Sá de Miranda em favor dele. Contudo, ele não teria apreciado as inúmeras piadas sobre padres, a menos que estivesse certo de que eles eram seguramente não-portugueses. ${ }^{199}$

De fato, D. Henrique, admirador do teatro mirandino, como afirma Earle, teve papel importante na apresentação do novo gênero ao público português, fazendo representar e imprimir aquelas peças clássicas, tanto que é a ele que Sá de Miranda

\footnotetext{
${ }^{198}$ Entrevista com Pedro Garcez Ghirardi, tradutor de Orlando Furioso. In Cadernos de Literatura e tradução, n. 6. São Paulo: Humanitas - FFLCH / USP, 2005, p. 183.

${ }^{199}$ Sá de Miranda's Roman Comedy. In: Cultural links between Portugal and Italy Renaissance. Ed. K. J.P. Lowe. Oxford: Oxford University Press, 2000, p. 154.
} 
dedica sua primeira comédia. Interessava ao cardeal não só que Portugal se emparelhasse culturalmente com a Itália, mas também conhecer os costumes italianos. Considerando ser a comédia um retrato da vida, nela buscou notícias do mundo de lá, lendo e relendo as peças do poeta que narrava suas próprias impressões do que viu e viveu em terras italianas. Segundo Earle, o cardeal pensava em fazer ele mesmo uma viagem a Roma.

Em 1559 ele foi candidato ao papado e obteve quinze votos no conclave. Ele, também, pode ter sentido a necessidade de conhecer a vida romana de dentro dela. Papas do período renascentista, como Pio IV, [...] eram reconhecidamente tolerantes e compreensivos com as artes. Henrique pode ter pensado, talvez, que seu patrocínio à comédia de Sá de Miranda fosse uma indicação de sua aptidão para o trono de São Pedro. ${ }^{200}$

Fossem quais fossem suas razões para apoiar a nova forma de expressão dramática, o fato é que esse apoio não chegou a sensibilizar de todo os corações patrícios. A comédia importada passou por um longo período de aclimatação às terras portuguesas e, ainda assim, não se pode dizer que chegou a se adaptar ao meio, o que se constata, facilmente, pelo pequeno número de comédias clássicas produzidas durante todo o Classicismo e pela verificação das datas relacionadas às peças: a primeira comédia é representada, pela primeira vez, em 1528; a segunda vem à luz em 1538; a primeira impressão de cada uma das comédias sai, respectivamente, em 1559 e 1560 - posteriormente, foram publicadas outras edições, e seus textos foram muito apreciados por filólogos e doutos em geral, mas há um intervalo de dez anos entre o surgimento da primeira e o da segunda comédia e de mais de trinta anos até sua publicação e o reconhecimento de seu valor literário. Levamos em conta também as duas comédias de António Ferreira, compostas na esteira de Sá de Miranda, que são dadas a conhecer na primeira década da segunda metade do século, quando o gênero, como literatura, já tem o seu valor, para verificarmos, então, que, depois delas, nada mais do teatro cômico erudito, na fôrma latina, foi produzido. Lembremos que Gil Vicente, num período

${ }^{200}$ Sá de Miranda's Roman Comedy, op. cit., p.163. 
equivalente, de pouco mais de trinta anos, compôs 44 peças $^{201}$ e teve seus epígonos, que, juntamente com um público cativo, não permitiram que o gênero vicentino desaparecesse.

Por seu próprio caráter intertextual, a comédia clássica, como a construíram Ariosto e Sá de Miranda, é um gênero teatral cujo valor reside na complexidade do texto, e não na graça fácil. É um teatro para ser lido, de preferência, na biblioteca, tamanha a quantidade de textos precedentes evocados. Não é que a peça não fizesse sentido no palco - tinha um enredo coerente, um fim moral e certa graça provinha dos jogos de palavras e das expressões da linguagem coloquial -, mas o reconhecimento do jogo alusivo faz parte do prazer que esse tipo de obra proporciona. Some-se a isso que as peças tinham pouca ação, caracterizando-se como fabula stataria, e que nem assunto nem personagens eram portugueses e é possível ter uma idéia do que foi a recepção deste gênero nos palcos. ${ }^{202}$ Os portugueses, habituados que estavam ao teatro simples, a tratar de assuntos locais e representar tipos populares, fizeram prevalecer a cena vicentina.

Em matéria de arte, Portugal apegava-se às próprias tradições. Seus poetas não deixariam de se exercitar nas velhas cantigas trovadorescas, nas redondilhas que continuariam a compor mesmo depois da revolução da "medida nova" promovida por Sá de Miranda, nem depois de ser o novo exercício poético teorizado por António Ferreira, único poeta português a aderir totalmente ao Classicismo. Sabe-se que estudantes bolsistas eram mantidos nas principais universidades européias e que professores estrangeiros eram contratados para lecionar nos cursos universitários portugueses; textos latinos eram estudados na Universidade, inclusive os de Plauto e Terêncio, bem antes da retomada dos clássicos antigos como ideal poético. "Aquela tradição não era de todo desconhecida em Portugal, desde a Idade Média as peças de Terêncio eram usadas como fonte de latim coloquial, com

\footnotetext{
${ }^{201}$ Número que consta na Compilação de todas as obras de Gil Vicente. Segundo Picchio (op. cit,. p.41) e Luiz Francisco Rebello, ele compôs cerca de cinqüenta peças. Citamos este último: "... Gil Vicente escreveu, interpretou e pôs em cena [...] cerca de cinqüenta autos, de que a maior parte foi reunida por seus filhos Luís e Paula Vicente numa Compilação editada em 1562 e reeditada vinte e quantro anos depois, com graves mutilações impostas pela censura inquisitorial." (História do Teatro Português. Lisboa: Publicações Europa-América, 1967, p. 29).

${ }^{202}$ Entenda-se por palco qualquer espaço onde as peças fossem encenadas.
} 
propósitos de ensino", lembra Earle. ${ }^{203}$ Ainda assim, tanto o gênero como o termo "comédia" parecem ter soado estranhos à audiência portuguesa. Esse estranhamento pode ser observado já no começo do prólogo de Os Estrangeiros: "Estranhais-me, que bem o vejo: que será? que não será? que entremês é este?" É a própria Comédia, feita personagem alegórica, que vem se apresentar:

Ora me ouvi, dir-vos-ei quem sou, donde venho, e ao que venho. Quanto ao primeiro, sou ũa pobre velha estrangeira, o meu nome é Comédia; mas não cuideis que me haveis de comer, porque eu naci em Grécia, e lá me foi posto o nome, por outras razões que não pertencem a esta vossa língua. ${ }^{204}$

Gil Vicente já havia denominado "comédia" uma das manifestações de seu variado teatro. Segundo Luciana S. Picchio, o termo foi adotado para designar os textos mais longos, que em nada se assemelhavam aos clássicos antigos, para assim diferenciá-los das farsas, que tinham, normalmente, um só ato. A estudiosa sugere que "talvez houvesse, da parte de Gil Vicente, alguma reminiscência erudita. Mas nada mais." ${ }^{205} \mathrm{O}$ "inventor" do teatro português jamais se renderia ao modelo importado da Itália, mas dava "... cada vez mais o nome de comédia a textos que nada têm de regular, que não obedecem a três, se não a três mil unidades", acrescenta Picchio. ${ }^{206} \mathrm{O}$ certo é que, embora chamadas comédias, as peças vicentinas não deixavam de ser autos e assim deviam ser compreendidas, não importando o título que recebessem. Mesmo Camões vai acomodar à redondilha os motivos clássicos de seu teatro e, respeitando a tradição local, no auge do Classicismo, denomina suas peças "autos". Era esse o modelo de teatro a que se familiarizara o público e daí ter Sá de Miranda que introduzir o novo gênero dando explicações e fazendo graça, como, por exemplo, a que fez através do trocadilho com a palavra comédia: "comedia" significava alimento. ${ }^{207}$ Os antigos tinham um nome para essa prática: captatio beneuolentiae.

\footnotetext{
${ }^{203}$ The Comedy of The Foreigners: Renaissance Sicily through Portuguese eyes. Oxford: Claredon Press, 1997, p. 8.

${ }^{204}$ Texto fixado por Rodrigues Lapa.

${ }^{205}$ História do Teatro Português. Lisboa: Portugália Editora, 1964, p. 73.

${ }^{206}$ Ibidem, p. 116.

${ }^{207}$ Cf. ROIG, A. O teatro clássico em Portugal no século XVI. Lisboa: Instituto de Cultura e Língua Portuguesa - Ministério da educação,1983, p. 18.
} 
Entre o público comum - lembrando que as peças eram representadas na corte, o que não significa que todos os que a freqüentavam fossem tão cultos quanto os príncipes que apoiaram a empreitada mirandina - a recepção não foi das mais calorosas. Para Picchio, a frieza da platéia, que contribuiu "para a falência da comédia erudita em Portugal", se deveu, além de à falta de familiaridade com o gênero, também à inabilidade dos autores portugueses para "organizar equilibradamente uma acção": ${ }^{208}$

E se, como em toda a parte, o povo não entende a nova comédia, em Portugal nem sequer a Corte se pode com ela divertir; as de Itália sim, que se riem e piscam o olho à decotada Mandragola, enquanto a de Lisboa boceja com os tímidos Vilhalpandos, Bristo e Cioso. ${ }^{209}$

A benevolência para com a comédia erudita parte de um pequeno grupo de pessoas de educação privilegiada, composto, segundo Remédios, pelo "escol da sociedade de então, príncipes, homens da igreja, fidalgos e literatos". ${ }^{210} \mathrm{E}$, a partir da apresentação feita por Sá de Miranda, a representação das comédias de Plauto e Terêncio acabou por tornar-se freqüente, principalmente no ambiente da Universidade, bem como a edição de seus textos em latim e também traduzidos. Não consta que antes disso os portugueses tivessem manifestado efetivamente qualquer interesse pelo gênero, como na Itália se manifestara já no século anterior. $\mathrm{E}$, depois disso, o interesse nesse teatro permaneceu exclusivamente pelo seu valor textual e de documentação histórica. Como espetáculo, a comédia clássica fracassou.

É como texto literário, primeiro representante da arte alusiva em Portugal - e é bom lembrar, como já o fez Earle, que Os Estrangeiros foi também a primeira comédia do Renascimento nos moldes clássicos de autoria não-italiana, ${ }^{211}$ o que coloca Portugal à frente até mesmo da França no cenário cultural da época - que a obra teatral de Sá de Miranda passa a ser analisada.

Como ficou registrado parágrafos acima, pareceu-nos que uma certa autonomia poética, própria do período na Itália, deveria transparecer nos textos de

\footnotetext{
208 Op. cit., p. 121.

209 Ibidem, p. 122.

210 Op. cit., p. 1052.

${ }^{211}$ The Comedy of The Foreigners, op.cit., p. 8.
} 
Sá de Miranda, considerando que foi do que presenciou lá, naquele momento, que Ihe veio a inspiração não só para a composição das comédias, mas também para a reforma que empreendeu na poesia portuguesa. De fato, o poeta segue à risca o modelo italiano das primeiras comédias recriadas, em especial o de Ariosto, que inovou ao construir seu texto como montagem de fragmentos de vários outros textos, técnica um pouco diferente da utilizada pelos comediógrafos latinos, a da contaminatio - que permitia a criação de uma fábula nova a partir da mistura de dois textos gregos, ou da inserção de uma cena de outro texto num texto principal - e mais próxima à de Virgílio na composição da Eneida. Também como fizeram os italianos, Sá de Miranda aproveitou-se do texto cômico para dar vazão à crítica aos costumes da época. A crítica aberta, em especial a dirigida ao clero corrupto, atesta que se vivia um momento de alguma liberdade de expressão que se refletiu no fazer poético - note-se que em António Ferreira a crítica à Igreja será mínima, não mais do que uma caricatura de certos frades bonachões. Mas, em Sá de Miranda, a crítica parece mais um sinal de adesão ao exemplo italiano, de imitação fiel do precedente sincrônico, do que propriamente de autonomia do poético, tão semelhante se faz ao modelo. Os provérbios e ditos populares comuns à audiência portuguesa, que vieram enriquecer seus textos e aproximá-los da realidade nacional, soam como novidade e expressão da criatividade do poeta, mas esse tipo de inovação já o trazia Plauto em suas comédias. O verdadeiro sinal de autonomia do poético em Sá de Miranda aparece quando ele escapa às regras - mas sem sair da fôrma - e se dá a liberdade de criar usando elementos de tradições diversas - liberdade que António Ferreira jamais buscaria. Bem nota Roig esse traço autêntico da comédia mirandina:

Há em Vilhalpandos a integração de trovas em versos tradicionais de sete sílabas - a esparsa composta por Vilhalpando I (III,2). [...] Para compor a sua esparsa, o capitão exprime-se na língua natal [o espanhol]. Uma vez mais se constata no comediógrafo português, no seio da comédia inovadora, de influência clássica e italiana, a coexistência de elementos tradicionais, próprios da literatura peninsular. ${ }^{212}$

O bilingüismo a que se permitiu Sá de Miranda também passará longe da obra de António Ferreira. Aliás, só na fôrma latina e na composição em prosa sua

${ }^{212}$ Op. cit., p. 34. 
comédia assemelhar-se-á à do mestre e à dos italianos. Numa análise, admitimos, não muito profunda das comédias do teórico do Classicismo português observamos que não foi somente dessas pequenas liberdades poéticas que se afastou Ferreira de seus antecedentes literários próximos. Também não foi o mesmo do mestre nem o dos predecessores italianos o procedimento adotado por este poeta na construção de suas comédias. O discípulo de Sá de Miranda, observando todas as regras e convenções do gênero, faz várias referências à Antigüidade Clássica, à História antiga e a muitos de seus personagens; diversos temas e situações encontrados em várias comédias latinas são evocados e, em especial, seus tipos; mas raras são as paráfrases $^{213}$ e somente duas citações com pequenas modificações foram por nós percebidas. ${ }^{214}$ António Ferreira tem, assim, um método próprio de recriação poética,

${ }^{213}$ Citamos duas, ambas em Bristo: a primeira, alude a Sá de Miranda, n'Os Vilhalpandos, I,1, e mostra o diálogo entre os senes (Bristo, I,3); a segunda alude à Celestina, I,10 (Bristo, II,1), parafraseando a fala da lena, no modelo, na do leno da imitação de Ferreira, como seguem:

Vilhalpandos.

Pompónio - Boa seja a vinda, Mário que em tua busca ia.

Mário - Ó Pompónio, e eu na tua! ...

Bristo

Calidonio - Oh Roberto, Deos venha contigo, agora hia a tua casa.

Roberto - E eu venho em tua busca.

Celestina

Celestina - ... Não há coisa mais perdida, filha, do que o rato que conhece um só buraco.

Bristo

Bristo - Bom está o rato, que não tem mais que hum buraco.

É bom que se saiba que, no caso da primeira, a alusão já se fazia em Sá de Miranda à Andria, III,3, de Terêncio, também entre os senes Cremes e Simão:

Cremes - Oh, andava mesmo à tua procura!

Simão - E eu à tua: chegas mesmo a propósito.

Mas este parece ser um diálogo formular, encontrado em diversas comédias com pequenas variações, portanto, teria sido usado pelo poeta de Bristo apenas como fórmula própria do gênero. Mas o fato de António Ferreira ter-se referido a Sá de Miranda, no prólogo desta comédia, como um de seus modelos, faz crer que ele deliberadamente aludiu aos velhos do mestre. É semelhante o que se dá com a segunda paráfrase identificada. Poderia tratar-se apenas de um dito popular comum à Espanha de Rojas e ao Portugal de Ferreira à época, portanto uma alusão percebida pelo leitor de aqui e agora e não para o autor do Quinhentos português. Mas a alusão à Celestina transparece já na personagem principal, o alcoviteiro Bristo, que em muitas passagens da peça evoca a mais famosa das alcoviteiras. São, assim, paráfrases possíveis, mas não prováveis, considerando ainda que são as únicas - parece não ter sido através de paráfrases e citações literais que António Ferreira promoveu o jogo intertextual em suas comédias.

${ }^{214}$ São ambas da Celestina (na tradução brasileira, ato II, 5), encontradas em Bristo, IV, 7: Celestina

Celestina - Justiça! Justiça! Senhores vizinhos! Justiça! 
que, diferentemente de Sá de Miranda, não segue o do modelo de Ariosto. A observação fica aqui como mote para um futuro estudo comparativo entre estes dois autores que marcaram a história da literatura portuguesa.

\section{Os Estrangeiros}

\subsection{Da peça}

É difícil precisar a data de composição desta peça - como a do restante da obra de Sá de Miranda - primeiramente, por falta de documentação, depois, porque o poeta retocava constantemente seus textos, atualizando-os. Dessa forma, um dado, no próprio texto do autor, que poderia revelar algo sobre a época de sua composição, consta em uma versão mas não em outra.

A maioria dos estudiosos do teatro português por nós consultados acredita que Sá de Miranda escreveu sua primeira comédia depois de deixar a Itália, em 1526, talvez durante uma passagem pela Espanha, antes de seu retorno a Portugal, ou logo em seguida. O único dentre esses autores que arrisca afirmar uma data é Fidelino de Figueiredo: "Foi durante a curta estada de D. João III em Coimbra, em 1527, que Sá de Miranda compôs a sua primeira tentativa de theatro classico, a comedia Os Estrangeiros." 215 A hipótese mais recente foi levantada por Thomas Earle, autor de vários trabalhos sobre a comédia mirandina, que diz haver evidências, no próprio texto da comédia, de que ela teria sido escrita durante a estada do poeta português na Itália.

\section{Bristo}

Liscisca - Justiça, justiça, ah que da justiça.

e

Celestina

Semprônio - Foge, foge, Parmeno, que vem muita gente!

Bristo

Pilarte - Vamo-nos, que acode gente.

${ }^{215}$ Historia da Litteratura Classica. Lisboa: Livraria Clássica Editora, 1922, p. 103. 
Todos aqueles que escreveram sobre a peça declaram, sem justificar seus pontos de vista, que ela foi concluída em 1526 ou 1527, depois do retorno de Sá de Miranda a Portugal. Se assim fosse, ele teria adotado a perspectiva do viajante que está de volta, que olha para suas experiências passadas, com todo o senso de superioridade que deriva de estar em casa, e compara sua própria sociedade favoravelmente com a estrangeira. Contudo, a peça não dá essa impressão. Ao contrário, ela é escrita de dentro da experiência no exterior, e é, como foi, um relato vindo diretamente do correspondente estrangeiro que não pode deixar de fazer parte da vida que descreve. [...] Ele a termina não depois de seu retorno a Portugal mas em 1523 ou 1524, enquanto ainda estava na Itália. ${ }^{216}$

Como se vê, Earle justifica seu ponto de vista, mas é, ainda assim, uma hipótese. De certo, temos somente que em 1527 Sá de Miranda estava de volta a seu país e que em 1528 fazia representar para a corte em Coimbra a peça que inaugurou o teatro clássico português, a comédia em prosa Os Estrangeiros.

A peça foi publicada postumamente em 1559, numa primeira versão que parece não ter sido autorizada, ${ }^{217}$ e, depois, em 1561, em versão que é considerada definitiva. A primeira edição, de João da Barreira, na qual não consta a dedicatória que Sá de Miranda faz ao cardeal D. Henrique e que precede a comédia na edição de 1561, nunca foi reimpressa, talvez, por se tratar de uma versão anterior aos últimos retoques feitos pelo poeta e, por isso, não autorizada. Na segunda edição, de António de Maris - provavelmente a que traz o texto aprovado pelo poeta baseiam-se todas as edições seguintes, inclusive a que seguimos neste trabalho, a de Rodrigues Lapa, publicada pela Livraria Sá da Costa. ${ }^{218}$

Segundo Earle, "nenhuma comparação detalhada das duas versões foi jamais realizada", ${ }^{219}$ e essa é uma tarefa que dificilmente será levada a cabo, pois existe somente um exemplar da primeira edição, da coleção de Fernando Palha, recolhida à Universidade de Harvard. Nas duas versões, ação e personagens são as mesmas, mas a linguagem é diferente do começo ao fim da peça, de acordo com a pesquisa

\footnotetext{
${ }^{216}$ The Comedy of The Foreigners, op. cit., p. 10.

217 Cf. FRANCO, Marcia Arruda. "Duas versões da dedicatória de Os Estrangeiros, de Sá de Miranda", trabalho apresentado no $2^{\circ}$ Colóquio do PPRLB, em abril de 2004, e publicado na Internet: www.realgabinete.com.br/coloquio/autor.asp?indice $=45$.

${ }^{218}$ Cf. EARLE. The Comedy of The Foreigners, op. cit., p. 11, nota 21. Ver também, sobre a impressão das comédias, p. 19.

${ }^{219}$ Rhetoric and Drama: the two versions of Sá de Miranda's Os Estrangeiros, op. cit., p. 35.
} 
de Remédios. ${ }^{220} \mathrm{O}$ trabalho de comparação empreendido por Earle esclarece um pouco mais:

Há o mesmo número de atos e cenas, e a trama complexa desenvolve-se da mesma maneira. Contudo, o modo como as personagens se expressam é surpreendentemente diferente. Muito poucas falas são as mesmas nas duas edições ... ${ }^{221}$

A impossibilidade de acesso à rara cópia da primeira edição empobrece sobremaneira nosso trabalho de pesquisa. A comparação detalhada entre as duas versões, certamente, traria à luz evidências do processo de criação do poeta.

Muito do que se tem escrito até hoje sobre as comédias mirandinas são suposições, hipóteses que não se podem provar. Não há nenhuma cópia autógrafa, nem documentos que atestem a vontade do autor.

\subsection{Da dedicatória}

A edição de 1561 traz à frente uma dedicatória ao Infante Cardeal Dom Henrique, na qual o autor informa sua intenção de imitar os latinos Plauto e Terêncio, do mesmo modo que estes procederam com os modelos gregos em sua época, e, ainda, de seguir os passos de escritores clássicos italianos, especificando Ludovico Ariosto, também seguidor das pegadas dos latinos.

Nas comédias antigas, essas informações costumavam vir no prólogo, que indicava também em qual ou quais comédias seus autores se basearam, além de informar o argumento da comédia.

Os prólogos de Sá de Miranda não trazem essas informações. É nessa Dedicatória que precede a comédia Os Estrangeiros que encontramos alguns dados necessários, não só para a análise da própria peça, mas para entender o modus operandi de Sá de Miranda na composição de suas comédias.

\footnotetext{
${ }^{220}$ As comédias de Sá de Miranda, op. cit., p. 1041.

${ }^{221}$ The Comedy of The Foreigners, op. cit., p. 20.
} 
O autor inicia a dedicatória desculpando-se de "querer às vezes arremedar Plauto e Terêncio" mas não explicita quais comédias quis "arremedar":

No que V. A. manda, que se pode dizer mais? A Comédia qual é, tal vai, aldeã e mal ataviada. Esta só lembrança lhe fiz à partida, que se não desculpasse de querer às vezes arremedar Plauto e Terêncio, porque em outras partes lhe fôra grande louvor ... ${ }^{222}$

Ora, são vinte as comédias de Plauto e seis as de Terêncio que chegaram à Idade Moderna e que, somadas às cinco de Ariosto, que reconhecemos também terem sido modelos para Sá de Miranda pela seqüência "e se mais também Ihe acoimassem a pessoa de um Doutor, como tomada de Ludovico Ariosto," totalizam trinta e um paradigmas para análise, sem considerar que outras comédias italianas de outros autores podem também ter-lhe servido de modelo, sem que isso fosse informado.

O tipo "doutor", criação de Ariosto, foi tomado de empréstimo da comédia I Suppositi e serviu de modelo para o Petrônio de Os Estrangeiros. Isso descobrimos lendo uma por uma as comédias ariosteas, pois a informação de que dispúnhamos não era de grande ajuda. A descoberta de uma outra versão da dedicatória, manuscrita, ${ }^{223}$ que teria sido a primeira, trouxe um pouco mais de luz para nossa pesquisa. Nessa versão, aparecem mais detalhes sobre a importância de Ariosto para o trabalho de Sá de Miranda:

No que V. A manda não há que dizer mais. Qual a Comédia é tal vai aldeã e mal ataviada. Fiz-lhe somente duas lembrãças a sua partida. Hũa que fizesse o coração tão largo pera a terra a que hia onde Ihe muito [cumpria]. Outra que nunca se desculpasse de querer a lugares arremedar Plauto e Terêncio. Antes a quem lhe tanta honra fizesse sempre e agradecesse muito e tomasse em lugar de grande louvor. Também Ariosto, natural de Ferrara, homem nobre de muitas Letras e de muito engenho, em hũa sua Comédia Italiana assi mesmo em prosa meteu a pessoa dum doutor. Mas digo eu que se logo por isso fora defeso a todos fazer outro tanto, não houvera nas comédias antigas tantos enganos de escravos, tantos pais apertados, filhos pródigos,

\footnotetext{
${ }^{222}$ Utilizamos, aqui, a versão da dedicatória impressa na edição citada de Rodrigues Lapa: SÁ DE MIRANDA, Francisco de, Obras Completas / Francisco de Sá de Miranda. 2. ed. Texto fixado, notas e prefácio pelo prof. M. Rodrigues Lapa. Lisboa: Livraria Sá da Costa, 1942-1943, v. 2. (Coleção de Clássicos Sá da Costa).

${ }^{223}$ Manuscrito Asensio, apógrafo de cerca de 1540, que se encontra na Biblioteca Nacional de Lisboa.
} 
soldados bravos. Quanto mais que Ariosto não foi o primeiro. Há destes avogados em Terêncio, onde um afirma, outro nega e outro duvida. ${ }^{224}$

Sabemos, então, que Ariosto não era conhecido em Portugal à época em que Sá de Miranda escreveu a primeira versão da dedicatória, embora seu Orlando Furioso tivesse tido grande êxito e já fosse lido em toda parte logo após a sua primeira publicação em 1516. Conta Ghirardi que, em 1522, nomeado governador da Garfanhana, região perigosa e freqüentada por foragidos da justiça, ao aproximar-se da província que governaria, Ariosto foi atacado por um bando de salteadores:

Mas, ao obrigá-lo a entregar tudo o que levava, perceberam que ele tinha consigo o Orlando Furioso. Perguntaram-Ihe então se conhecia o autor daquela obra. Ao saberem que estavam diante do poeta, os bandoleiros não só lhe devolveram tudo, como o deixaram seguir entre aclamações, enquanto recitavam episódios do poema. ${ }^{225}$

Portugal permanecia de costas para o que acontecia fora de sua realidade ensimesmada. Um poeta como Ariosto precisava ser apresentado e a retomada dos clássicos da Antigüidade e do processo de imitação criativa, utilizada pelos romanos antigos e pelos renascentistas italianos, precisava de uma apologia: "porque em outras partes lhe fora grande louvor."

Aquelas "outras partes", mencionadas na versão impressa da dedicatória, em que fora grande louvor arremedar Plauto e Terêncio, se referem à Itália. Devido à importância que Ariosto teve na literatura italiana já à sua época, deduzimos que ele poderia ter exercido influência bem maior sobre Sá de Miranda do que pressupúnhamos, como de fato exerceu. Pelo menos mais uma de suas comédias inspirou ao poeta português, em seguida à d'Os Estrangeiros, a composição de Os Vilhalpandos: La Lena.

Franco, em trabalho sobre as duas versões da dedicatória de Os Estrangeiros, confirma que quando Sá de Miranda escreveu essa carta manuscrita, Ariosto ainda não seria familiar ao Cardeal e à corte, onde se representavam as comédias, por isso precisava de uma apresentação. Parece-nos que, do mesmo

\footnotetext{
${ }^{224}$ Esta edição da versão manuscrita é de FRANCO, op. cit..

${ }^{225}$ Poesia e loucura no Orlando Furioso. In: ARIOSTO, Ludovico, Orlando Furioso. Introdução, tradução e notas de Pedro Garcez Guirardi. Cotia: Ateliê editorial, 2002, p. 14.
} 
modo, esse tipo de comédia, baseada nas dos latinos, agora em prosa e língua vernácula, seria estranha à corte e, por isso, a necessidade de explicá-la. Quando, mais tarde, o poeta reescreveu a dedicatória que sairia junto à versão impressa, em 1561, após sua morte, Ariosto já não precisava de apresentações, suas comédias já deveriam ser conhecidas em Portugal, pelo menos a quem elas interessavam na corte.

Prosseguindo com a dedicatória, depois da referência ao Doutor, tomado de Ariosto, o autor refere-se aos três advogados de Terêncio:

... e se mais tambem the acoimassem a pessoa de um Doutor, como tomada
de Ludovico Ariosto, que lhes pusesse diante os três advogados de Terêncio,
dos quais um nega, outro afirma, o terceiro duvida, como inda cada dia
acontece: assi que des aquele tempo vem já o furto. ${ }^{226}$

Quanto aos três advogados a que ele alude, lembramos que são personagens da comédia Phormio, de Terêncio - Hegião, Cratino e Critão - que não são realmente advogados, senão amigos do senex chamados a the dar conselho, enquanto o tipo "doutor", criado por Ariosto, é um jurista, um tipo pedante. Em sua arrogância, o tipo nos remete muito mais ao miles gloriosus - este vangloriando-se de sua força, heroísmo e beleza física, aquele, de sua intelectualidade - do que aos três amigos do velho na peça de Terêncio. Tanto o Cleandro de I Suppositi de Ariosto, como o Petrônio d'Os Estrangeiros de Sá de Miranda nos fazem pensar num "doctor gloriosus", que se tornou arquetípico na literatura universal. Parece, então, ter havido um engano de Sá de Miranda na consideração deste objeto de "furto" de Ariosto - um Doutor inspirado nos advogados de Terêncio - e isso nos leva a crer que a comédia latina era pouco familiar também para ele.

No que diz respeito ao "furto", que é como Sá de Miranda denomina a imitação, Franco, no trabalho citado, diferencia os dois autores, Ariosto e Sá de Miranda, justamente pelo tratamento dado ao "mecanismo criativo da imitatio", lembrando que Ariosto também usa o termo "furto" no prólogo de I Suppositi:

${ }^{226}$ Edição de Rodrigues Lapa. 
... perché non solo ne li costumi, ma ne li argomenti ancora de le fabule vuole essere de li antichi e celebrati poeti, a tutta sua possanza, imitatore; e come essi Menandro et Apollodoro e li altri Greci ne le lor latine comedie seguitoro, egli così ne le sue vulgari e modi e processi de' latini scrittori schifar non vuole. Come io vi dico, da lo Eunuco di Terenzio e da li Captivi di Plauto ha parte de lo argumento de li suoi Suppositi transunto, ma sì modestamente però che Terenzio e Plauto medesimi, risapendolo, non l'arebbono a male, e di poetica imitazione, più presto che di furto, gli darebbono nome. ${ }^{227}$

Mas Sá de Miranda não usa o termo imitação em nenhuma das duas versões, como observa Franco:

Se nas duas versões da dedicatória mirandina importa caracterizar a imitação como inerente ao processo criativo do teatro antigo, o termo imitatio nunca é usado, quer na carta manuscrita,

Mas digo eu que se logo por isso fora defeso a todos fazer outro tanto, não houvera nas comédias antigas tantos enganos de escravos, tantos pais apertados, filhos pródigos, soldados bravos. Quanto mais que Ariosto não foi o primeiro. Há destes avogados em Terêncio, onde um afirma, outro nega e outro duvida. Já Túlio ameaçava seu amigo Trebácio, tamanho jurisconsulto, com as graças de Labério, e veio todavia a cair nas de Horácio, os comentos me perdoem, que al cuidavam. Assi que a Invenção antiga é

quer na versão impressa,

Tulio cõ/ que ameaçava já seu amigo Trebacio, tama /nho lurisconsulto, se não com as graças de / Laberio? \& Oracio cõ quantas de suas gra-/ças passa hum sermão co mesmo Trebacio?/

Nas duas versões, adverte que não é preciso desculpar-se por "querer a lugares arremedar Plauto e Terêncio" "porque em outras partes the fora grande louvor". Na versão impressa, porém, a palavra usada para caracterizar a imitatio é justamente "furto": "assi que des aquelle tempo vem ja o furto". Em outras palavras, importa a Sá de Miranda caracterizar o furto como processo criativo digno de louvor, enquanto no prólogo de I Suppositi, Ariosto prefere logo, como se diz, "dar nome aos bois", chamando o processo criativo de "imitação poética" e não de "furto". 228

\footnotetext{
${ }^{227}$ ARIOSTO, op. cit., grifos nossos. "...porque não só nos costumes, mas também nos argumentos das fábulas quer ser dos antigos e celebrados poetas, em toda a sua potência, imitador; e como esses seguiram Menandro e Apolodoro e os outros gregos em suas comédias latinas, ele, da mesma forma, nos seus vulgares modos e processos, não quer desdenhar dos escritores latinos. Como eu vos digo, do Eunuco de Terêncio e dos Cativos de Plauto extraiu parte do argumento dos seus Suppositi, mas tão modestamente todavia que, se os próprios Terêncio e Plauto o soubessem, não o levariam a mal, e de imitação poética, muito antes que de furto, Ihe dariam nome."

${ }^{228}$ FRANCO. "Duas versões da dedicatória de Os Estrangeiros, de Sá de Miranda".
} 
Em outro trecho da versão manuscrita da dedicatória, Franco vê "uma referência ao trabalho do comediógrafo como um passatempo que, apesar de remontar a uma invenção dos tempos antigos, ao contrário do moderno título de doutor, pode ser visto como afim da caça e do jogo e por isso isento da necessidade de louvor". ${ }^{229}$ Eis a referência na dedicatória:

Assim que a invenção antiga é, ainda que o título de doutor não seja antigo, nem daquele comedimento que foi o de filósofo, mas, ilustre senhor, é como dizem andar pelas ramas, que mui levemente pudera passar a perda deste trabalho e muito mais a do louvor. O trabalho tomei por meu passatempo. Assim como alguns caçam outros jogam, no louvor nunca cuidei. ${ }^{230}$

$\mathrm{Na}$ seqüência, o poeta fala até mesmo em "queimar tudo" e Remédios questiona a sinceridade destas afirmações:

Escreveria êle com efeito por mero passatempo? Seria para entreter horas de ócio e estas roubadas a cuidados mais altos e mais proveitosos? Em tão pouca conta tinha êle a sua obra, que julgasse preferível a estampá-la o estingui-la pelo fogo? Não tomemos à letra tais confissões, que eram mais uma imagem poética, que o significado exacto da verdade. ${ }^{231}$

Para corroborar seu ponto de vista, Remédios argumenta: "Também António Ferreira na Carta dedicatória ao Príncipe D. João, com que abre a Bristo, afirma tê-la escrito 'por seu desenfadamento em certos dias de férias e ainda êsses furtados ao estudo"'.232

A nosso ver, em ambos os casos as afirmações dos poetas portugueses soam como captatio beneuolentiae e não demonstram se aquele foi ou não mais do que um exercício intelectual.

A grande diferença entre Sá de Miranda e Ariosto parece residir mesmo no modo como cada um avalia e apresenta seu trabalho de imitação: um como procedimento poético, avalizado pelos antigos, de reelaboração criativa de um gênero - e não só de um texto específico - e o outro como passatempo. Mas há na

\footnotetext{
${ }^{229}$ FRANCO. "Duas versões da dedicatória de Os Estrangeiros, de Sá de Miranda".

${ }^{230}$ A edição deste trecho da dedicatória é nossa. Empreendemos duas edições da versão manuscrita completa, uma semidiplomática e outra modernizada. Ambas encontram-se nos apêndices, ao final desta dissertação.

${ }^{231}$ Op. cit., p. 1047.

232 Ibidem.
} 
dedicatória uma contradição: se Sá de Miranda caracteriza o furto "como processo criativo digno de louvor", ele não seria somente "passatempo", e se é mero "passatempo", não deveria ser digno de louvor. Por fim, ele declara: "No louvor nunca cuidei". Se para Sá de Miranda o exercício poético da imitatio é mesmo um passatempo, uma distração como outra qualquer, como se observa na versão manuscrita, confirma-se a nossa tese de que o autor praticou a imitação na comédia como mero exercício intelectual, e explica-se o fato de não transparecer em seus textos uma alma, algo que os torne propriamente seus, como se percebe na obra de Ariosto.

\subsection{Do jogo alusivo - o diálogo intertextual}

\subsubsection{A arquitextualidade}

Sá de Miranda dá início ao jogo alusivo ao escolher um gênero clássico e esforçar-se por inserir sua composição numa tradição genérica. Para tanto, o escritor precisa imprimir na obra marcas do gênero escolhido e com elas evocar todo um conjunto de textos. A esse tipo de evocação primeira e superficial denominamos, conforme Genette, arquitextualidade.

Desde a divisão da peça em prólogo e cinco atos, como sugere Horácio, até a representação da vida do homem comum e seus pequenos vícios, como determina Aristóteles; da repetição de fórmulas, de temas e tipos, enfim, de loci da comédia latina, ao cumprimento de regras e convenções características, o hipertexto dialoga com um "Modelo-Gênero". O autor, nas palavras de Vasconcellos, "constrói um 'análogo' do modelo, tratando-o como 'uma espécie de matriz gerativa'."233

Segundo Vasconcellos, "trata-se de reproduzir não uma passagem qualquer de um precursor, transformado-a seja como for, mas de concretizar, reatualizando, na nova obra as regras de um código, extraídas de todo um repertório de textos

\footnotetext{
${ }^{233}$ Op. cit., p. 42. As expressões citadas por Vasconcellos são de Barchiesi e Conte, "Imitazione e Arte Allusiva. Modi e Funzioni dell' Intertextualità". In: CAVALLO, Guglielmo et alii (direttori). Lo Spazio Letterario di Roma Antica. Roma, Salerno, [1989], p. 94-95.
} 
paradigmáticos."234 Quando a retomada é de loci determinados de um precursor, este será um "Modelo-Exemplar" para o poeta. ${ }^{235}$

Sá de Miranda começa por identificar o gênero, pouco familiar ao público português, no prólogo, fazendo com que a própria Comédia, como personagem alegórica, se introduza, apresentando um breve histórico do gênero. A Comédia diz a que vem: "Eu trato cousas correntes, sou muito clara."

É no prólogo, também, que conhecemos o local da ação: "Palermo, cidade nobre da Sicília". Aí encontramos mais um dos componentes da arquitextualidade de Os Estrangeiros. A ambientação da comédia numa cidade estrangeira é uma das marcas do gênero cômico. Earle atribui a Terêncio o estabelecimento dessa convenção, ${ }^{236}$ mas mesmo antes, em Plauto, ela já era observada. Nas comédias latinas a ação transcorria sempre em uma cidade grega e Ariosto dava início à imitação desses textos clássicos ambientando sua primeira comédia na ilha de Lesbos, na Grécia, mantendo a convenção latina. Mas todas as suas outras comédias, assim como todas as outras comédias italianas do período, foram ambientadas em cidades italianas.

Quis Sá de Miranda dizer algo ao estabelecer a cena de suas comédias na Itália e não na Grécia, como o fizeram os predecessores latinos? Nossa interpretação deste fato é que o poeta português quis identificar seu "modeloexemplar" como sendo o italiano - se os predecessores latinos estabeleciam sua cena no ambiente original do modelo, a Grécia, ele também o faria, ambientando sua comédia na Itália de seu modelo. O poeta mantém, assim, a convenção de fazer transcorrer a ação da peça no estrangeiro e, ao mesmo tempo, declara a que tradição se filia. Confirma-se nossa interpretação se associarmos a este um outro fato, ligado ao modo de enunciação. Ao adotar a prosa, Sá de Miranda avisa que seu principal modelo é Ariosto, que vai imitar os latinos como Ariosto o fez, recriando a comédia em prosa. Ele filia-se a toda uma tradição teatral cômica que principia na Grécia e se mantém nos latinos, mas é a versão moderna que a comédia tomou no Renascimento, sem métrica e em língua vernácula, que ele vai seguir.

\footnotetext{
${ }^{234}$ Op. cit., p. 42.

${ }^{235}$ Ibidem.

${ }^{236}$ Sá de Miranda's Roman Comedy, op. cit., p. 154.
} 
Também o argumento da peça traz marcas do gênero. O tema da criança perdida, criada por uma família pobre e, mais tarde, reconhecida como filha de uma família importante, é freqüente nas comédia latinas. O enredo da peça baseia-se neste tema, girando em torno da bela Lucrécia, moça pobre de Florença (na comédia paliata, corresponde à personagem feminina que não tem cidadania ateniense), que, não tendo dote, deverá se casar com quem "a tomará em camisa". Ela tem três pretendentes: um jovem sem fortuna própria (adulescens), um velho jurista rico (o "doutor") e um capitão (miles gloriosus). Com a ajuda de criados, alcoviteiros e parasitas, os três tentam conquistá-la. Seu casamento com o jurista Petrônio está quase certo, quando a chegada inesperada de alguém de fora acarreta seu reconhecimento como afilhada do doutor - que sendo um segundo pai não deve desposá-la. Ela pode, então, casar-se com o jovem a quem realmente ama. Exceto pelo "doutor", presente de Ariosto, todos os outros tipos provêm da comédia latina. Temas e tipos são genéricos evocando o conjunto de comédias precursoras.

Os Estrangeiros é uma comédia de reconhecimento, embora apresente também tipos e motivos próprios das comédias de enganos: o parasitus e o miles. Quanto à ação, trata-se de uma fabula stataria. A ação é lenta, faltam conflitos e enganos, seguindo, assim, mais proximamente o paradigma terenciano do que 0 plautino.

Embora parta de um tema comum, Sá de Miranda inova, criando um ambiente onde todos os protagonistas são estrangeiros, numa Itália invadida por espanhóis, e evocando uma situação recente da história italiana. Inova também quanto aos nomes dados às personagens, nenhum comum à comédia precursora, mas mantém um artifício dos antigos ao nomeá-los, que, como lembra Earle, é tomado de Plauto: o nome das personagens como chave para o seu caráter. Assim temos um adulescens louco de paixão chamado Amente (demente, insensato), um parasitus edax (parasita glutão) chamado Devorante, um miles gloriosus de nome Briobris (de brio, valentia), um seruus callidus, o criado astuto Calídio, cujo nome evoca o próprio tipo da comédia latina. ${ }^{237}$

${ }^{237}$ Cf. EARLE. The Comedy of The Foreigners, op. cit., p. 11-12. 
Mas não é somente a uma tradição genérica que o poeta busca se filiar. Ele demonstra desejar inserir-se em toda uma cultura que considera modelar, a da Antigüidade. Já na dedicatória evoca os antigos, como ao aludir à Poética de Aristóteles:

A Comédia, tam estimada nos tempos antigos, que al disseram aqueles grandes engenhos que era, senão ũa pintura da vida comum? À dos Principes se repartiu a Tragédia. ${ }^{238}$

e aos costumes relatados nas épicas antigas de bem receber os estrangeiros:

... e pedir-lhe que empare estes Estrangeiros como fazem os grandes Príncipes, e de cujo emparo sómente confiam os que vão por terras alheas.

Menciona também nomes de personalidades da Antigüidade: Pitágoras, Cícero (a quem o poeta nomeia Túlio), Trebácio (jurisconsulto, amigo de Horácio, com quem este dialoga na Sátira, II, 1), Labério (autor de mimos, citado por Horácio na Sátira, I, 10) e o próprio Horácio.

Desde a dedicatória temos uma demonstração do grau de erudição necessário para se fazer compreender à platéia ou ao leitor um texto como este (e ainda estamos tratando somente da arquitextualidade!), de onde se conclui que a audiência se compunha de uns poucos letrados - Odi profanum vulgus! Esta comédia não vinha, assim, divertir o povo, como nos jogos e competições antigos, mas enlevar eruditos.

\subsubsection{A supercontaminação}

Os temas que serviram de mote para esta comédia mirandina - e que remetem à arquitextualidade do texto - são tantos e provindos de tão diversos hipotextos que temos assim um caso de supercontaminação de motivos.

${ }^{238}$ Edição de Rodrigues Lapa, nesta e na citação que se segue. 
Do Eunuchus, adaptação de Terêncio da comédia de mesmo nome de Menandro, vem com mais força o motivo da moça pobre que se perdeu dos pais e que no final é reconhecida como cidadã e filha de família iportante. Mas o mesmo motivo pode ser encontrado em Phormio, Andria e Heautontimorumenos, também de Terêncio, e em Rudens, Epidicus e Casina, de Plauto. A personagem não tem fala na comédia mirandina, como também não tem na maioria das comédias latinas, mas o enredo se desenvolve em torno dela.

O jovem apaixonado pela moça pobre, que por qualquer razão se encontra impedido de realizar o seu amor, e que chega a desejar a morte, é personagem patético, que aparece na maioria das peças precursoras.

O jovem desolado por pensar que foi traído pelo amigo pode ser observado em Bacchides (Plauto) e Heautontimorumenos (Terêncio) - e será retomado em Bristo, de Antônio Ferreira.

O motivo do pai ausente e de seu regresso imprevisto encontra-se em Phormio, de Terêncio, Trinummus e Mostellaria, de Plauto e em La Cassaria e I Suppositi de Ariosto.

De Truculentos, comédia plautina, vem o motivo dos três homens apaixonados e em disputa pelo amor de uma mesma mulher. Em Plauto, os três são jovens, um do campo, um da cidade e o último é, como Briobris, um soldado fanfarrão que vem de fora. A grande diferença é que em Truculentos a pretendida é uma meretrix e não a uirgo mirandina.

O motivo das fanfarronices do soldado está presente, mas será melhor explorado em Os Vilhalpandos, assim como o do parasita bajulador, sempre a acompanhar o miles. N'Os Estrangeiros, o conteúdo das falas do soldado Briobris e do parasita Devorante é imitado dos modelos, mas não há citações nem chega a ser paráfrase. Interessante é um monólogo do parasita que vem explicar a relação entre estes dois tipos:

... lembrou-se Deus de mim, e acudiu-me co êste soldado apetitoso, convidador, mais vão que a mesma vaidade, nas armas um Roldão, mais fermoso e mais namorado de si que Narciso. Mas a mim que se me dá? [...] É de louvaminhas: farto-o delas. Quer contar suas mentiras, aparelho os ouvidos, encho-o de vaidade, e êle a mim, que não sou tão espiritual, encheme disso que se vende na praça. Seja nas boas horas; dure o que durar. É 
enfadonho? Não há logo de ser tudo como homem quer; e de que me podem melhor servir os meus ouvidos e a minha língua, que me de ganharem de comer? (II, 2)

Note-se a alusão a Orlando, o Roldão, soldado do exército de Carlos Magno, que é citado também em outra passagem da comédia (II, 1), ao lado do companheiro Rinaldo, ambos personagens do Orlando Furioso, de Ariosto, e das narrativas do ciclo carolíngeo, no diálogo entre Briobris e Devorante:

Dev.: - Assi contam que se toma o alicorne, animal tam bravo.

Bri.: - E assi aconteceu a Roldão e Reinaldo.

Narciso entra no rol das alusões mitológicas, juntamente com Hércules (II, 1), mencionado nesta mesma cena:

Bri.: - Assi que me tendes cativo em Palermo, em tempos de paz e terra de Cristãos?

Dev.: - São obras do Amor, que já fez a Hércules, conquistador do mundo, fiar e debar.

Vai Sá de Miranda, assim, amalgamando elementos de toda uma cultura que o precedeu e que admira, como faz com os textos da tradição, que considera exemplares.

Se o tema central da comédia - o do desencontro amoroso (aqui, a jovem desafortunada, perdida da família, que ama um rapaz sem fortuna própria, cuja relação amorosa só poderá se concretizar após o reconhecimento de sua real situação social) - e todos os outros satélites remetem a um "modelo-gênero", formado por todo um conjunto de textos de uma tradição literária, um outro tema está na base d'Os Estrangeiros, remetendo a seu "modelo-exemplar", a comédia I Suppositi, de Ariosto. Mais do que o tipo "doutor", I Suppositi forneceu o tema do senex puerilis, encarnado pelo velho jurista, que se apaixona pela mocinha, que, por sua vez, ama um jovem estudante forasteiro - a ação passa-se em Ferrara, centro cultural da Itália, e o estudante é siciliano -, cujo pai chega inesperadamente para 
visitá-lo. Petrônio, o velho "doutor" d'Os Estrangeiros, é tal e qual seu modelo, o Cleandro de I Suppositi, pedante, narcisista, sempre acompanhado de um adulador, como ocorre com o miles - um próprio doctor gloriosus. É de assinalar-se a semelhança dos diálogos entre estes tipos, o fanfarrão e o adulador, nas duas peças. Em I Suppositi $(I, 2)$ dialogam Cleandro e Pasifilo, o parasitus edax:

Cle.: - Não havia agora, Pasifilo, gente diante daquela porta?

Pas.: - Sim, havia, sapientíssimo Cleandro. Não viste tua Polinesta?

Cle.: - Era a minha Polinesta? Por Deus, não a reconheci.

Pas.: - Não me espanto: hoje o ar está agitado e meio nebuloso, e eu só a reconheci pelas roupas ...

Cle.: - Eu, graças a Deus, para minha idade tenho muito boa vista e sinto em mim pouca diferença daquele que fui aos vinte e cinco ou trinta anos.

Pas.: - E por que não? Tu és, por acaso, velho?

Cle.: - Eu tenho cinqüenta e seis anos.

Pas.: - (Diz dez a menos!)

Cle.: - Que dizes tu: dez a menos?

Pas.: - Digo que te estimava dez anos a menos. Não aparentas passar de trinta e seis, ou trinta e oito, no máximo.

Cle.: - Eu tenho, no entanto, a idade que te conto.

Pas.: - Em boa idade estás tu, e a tua disposição promete que te fará chegar aos cem anos ...

N'Os Estrangeiros (III, 2), um dos diálogos é entre Petrônio e sua criada Sargenta, que também o adula:

Petr.: - Vem cá, Sargenta, chega-te mais a mim que te quero preguntar donde vens.

Sar.: - E logo te o coração disse donde?

Petr.: - Que maravilha! se êle sempre por lá anda.

Sar.: - E a mim me parece que o vi.

Petr.: - Folgo com isso muito. E pois que anda a minha alma fazendo por lá?

Sar.: - Espalhando torvoadas como sino de virtudes.

Petr.: - E parece-te que fica o céu despejado de todo? 
Sar.: - Limpo como um espelho.

Petr.: - Nem lá contra o Poente não enxergas nada?

Sar.: - Ũa pouca de névoa e vento.

Petr.: - Daí se levantam às vezes grandes torvoadas; mas que entendeste dela?

Sar.: - Muitos sisos e muitas virtudes.

$[\ldots]$

Petr.: - Ao homem sesudo tudo há de lembrar, e mais isto das idades releva muito.

Sar.: - E bem, que disposição é assi a tua?

Petr.: -- Da disposição, Deus seja louvado, não hei enveja a ninguém; a idade pola ventura parecerá mais do que é co's nojos e co's trabalhos com que se as cãs adiantam.

Sar.: - Quem não sabe que as cãs não fazem velhice?

Também nas citações em latim Cleandro e Petrônio se emparelham, embora as citações não sejam as mesmas. Em I Suppositi (I, 2), dialogam Cleandro e Pasifilo:

Pas.: -- Estas são verdadeiras virtudes. Que filosofia? Que poesia? Todo o resto das ciências, face àquelas das leis, me parecem conversa fiada.

Cle.: - Conversa fiada, bem disseste: unde uersus: Opes dat sanctio lustiniana; Ex aliis paleas, ex istis collige grana. ${ }^{239}$

Pas.: - Que bom! De quem é? De Virgílio?

Cle.: - Que Virgílio? É de um nosso comentário excelentíssimo.

N'Os Estrangeiros (III, 3), Petrônio e Devorante:

Petr.: - Assi podemos dizer co aquele nosso grande Justiniano: Noctes ducimus insomnes, etc. ${ }^{240}$

Dev.: - Pois dêsse vosso Justiniano não sei que eu já ouvi dizer.

Petr.: - E quê?

Dev.: - Que não fôra ele dos mais Católicos.

\footnotetext{
239 "A lei de Justiniano produz riquezas; das outras se tira a palha, desta o grão."

240 "Levamos as noites sem dormir."
} 
Petr.: - Oh! línguas de serpentes! escrevendo ele tam altamente de Summa Trinitate e Fide Catholica?

É perceptível que Sá de Miranda quis fazer ressoar na fala de Petrônio a voz de Cleandro, ao evocar o mesmo Justiniano.

Embora em tudo semelhantes, o "doutor" de Sá de Miranda teve mais espaço do que o de Ariosto. Sua presunção característica foi também mais explorada na comédia mirandina, demonstrando uma tentativa de aemulatio, a nosso ver, bem sucedida, do poeta português. Através de Petrônio, Sá de Miranda pode fazer seu texto evocar mais naturalmente a poesia e a filosofia dos antigos, toda uma cultura na qual se quer inserir e que não caberia na voz de escravos e parasitas, a quem confia os provérbios da tradição local e os ditos populares. Deste modo, pode ele mesmo demonstrar sua erudição, como ao aludir a Ovídio, citando as Metamorfoses, XV, 234, em monólogo do jurista (III, 1):

Se nós outros passamos tam asinha, que podemos fazer que dure muito? Tempus edax rerum, tuque o invidiosa uetustas, omnia consumitis. ${ }^{241}$

E a Virgílio:

... agora que temos de Pisa senão pardieiros e campos ubi Troia fuit, ${ }^{242}$ como diz aquele divino Poeta?

E, ainda, na sententia da filosofia antiga:

... os homens não deviam de falar nas cousas do mundo senão despois de muita infinda experiência, que, segundo o Filósofo, est mater rerum. ${ }^{243}$

\footnotetext{
${ }^{241}$ Na tradução do editor: "Tempo devorador das coisas, e tu, ó ciosa velhice, tudo consumis." Earle (Rhetoric and Drama: the two versions of Sá de Miranda's Os Estrangeiros, op. cit., p. 38.) aponta um erro nesta citação: nas Metamorfoses, lê-se destruitis em lugar de consumitis. Verificamos, e a observação de Earle está correta. O estudioso acredita que, ou Sá de Miranda citou de memória, e enganou-se, ou usou alguma compilação de lugares-comuns das literaturas grega e latina, muito comuns naquela época, que trazia o erro.

242 "... onde existiu Tróia".

${ }^{243}$ A sentença é "A experiência é a mãe das coisas." Em nota do editor.
} 
Aproveitando-se da chegada por mar do mercador Guido - personagem que, como o Crito, de Andria, vem de fora para esclarecer a verdadeira situação de Lucrécia, a filha desaparecida de Reinaldo - Sá de Miranda evoca ainda Horácio, aludindo à aversão do poeta latino às viagens marítimas, pela voz do mercador:

Gui.: - Este mar tamanho, tam bravo, tam mudável, tam espantoso, quem ousou primeiramente de acometer?

A fala traz-nos imediatamente à lembrança a Ode, 1, 3, composta por ocasião de uma viagem por mar do amigo Virgílio: “... / Carvalho e tríplice bronze tinha / ao redor do peito quem primeiro / cometeu um frágil barco ao pélago bravio, /..."244

Tornando ao modelo-exemplar desta comédia mirandina, outra alusão a I Suppositi (IV, 7 e V, 1) está na sugestão do escravo Calídio ao jovem enamorado, Amente, de fingir não reconhecer o pai (Estr. IV, 6), estratégia utilizada pelo criado Dulippo, que, na comédia ariostea, se faz passar pelo jovem amo para confundir o velho patrão que chegara inesperadamente da Sicilia e iria atrapalhar os planos dos dois:

Dul.: - Esta foi mesmo uma grande desgraça, que antes que eu pudesse encontrar Erostrato, tenha tropeçado no velho patrão, por isso me foi conveniente fingir que não o conhecia ...

Não há citações nem paráfrases nas falas, Sá de Miranda alude a uma situação da comédia ariostea que repete na dele:

Cal.: - Ora bem vês que esta vinda de teu pai embaraça tudo, pelo qual aqui cumpre de acudir, se queres remédio.

Am.: - A maneira de acudir é a que não vejo.

Cal.: - Dir-to-ei. Façamos que não conhecemos teu pai, por mais Valenciano que fale.

${ }^{244}$ Tradução de Dante Tringali. Horácio poeta da festa: navegar não é preciso. São Paulo: Musa, 1995. "llli robur et aes triplex / circa pectus erat, qui fragilem truci / commisit pelago ratem / primus ..." 
A comédia Os Estrangeiros apresenta ainda outros temas provenientes da comédia italiana, que são os temas da ociosidade e corrupção dos clérigos e da degradação dos costumes em Roma, tomados especialmente da Mandrágora, de Maquiavel, que também serão mais explorados na comédia Os Vilhalpandos.

A rivalidade entre os servos, que se percebe nesta comédia mirandina, comparece em várias peças latinas, mas é em La Cassaria que vamos encontrá-la em situação semelhante à d'Os Estrangeiros. Diferentemente do que ocorre nas comédias latinas, um dos servos destas peças, o encarregado de cuidar do jovem amo durante a ausência do pai, tenta impedi-lo de realizar-se amorosamente, enquanto um outro vai contra o primeiro e busca ajudar o rapaz. Em La Cassaria, o "tutor" é Nebbia, um criado velho e ranzinza, fiel ao patrão. Sá de Miranda transfere estas mesmas características a Cassiano, o "tutor" de Amente. Com estes, os ladinos Volpino e Calídio, respectivamente, discutem e desentendem-se da mesma forma. Neste ponto, gostaríamos de fazer uma observação quanto à caracterização do tipo seruus: os da comédia mirandina são por demais desinteressados. Diferentemente do que fez com o tipo "doutor", que aperfeiçoou, na caracterização dos serui, tão importantes para a evolução da trama nas comédias, o poeta português deixou a desejar.

Encontra-se n'Os Estrangeiros também a figura de um casamenteiro, muito próxima da do tipo feminino lena - posto que seu correspondente masculino na comédia latina, o leno, é o mercador de escravas - mas não há um alcoviteiro assim caracterizado nem na comédia latina, nem na italiana. Sá de Miranda pode ter tentado amenizar a imoralidade que caracterizava este tipo, denominando-o, eufemisticamente, casamenteiro - aquele que arranja casamentos e não o que promove encontros entre amantes. Segundo Roig, o casamenteiro é uma figura da realidade portuguesa da época, que já aparecia nos autos de Gil Vicente. ${ }^{245}$

Roig lembra ainda dos astrólogos e físicos mencionados por Petrônio (III, 4), que também tomavam parte na "hierarquia em vigor no Portugal da época."246 Astrólogos e nigromantes exerciam grande poder sobre as pessoas no Quinhentos, que ainda acreditavam em bruxarias, e não só em Portugal. Ariosto, Maquiavel e

\footnotetext{
${ }^{245}$ Op. cit., p. 27.

${ }^{246}$ Ibidem.
} 
Bibbiena criticam duramente em suas comédias essa sociedade que se entrega a essa espécie de charlatanismo. N'Os Estrangeiros, Sá de Miranda faz somente essa menção, na voz do "doutor": "Os Astrólogos sempre tratam do por vir, de que eles nem ninguem sabe pouco nem muito." Como o tema será retomado n'Os Vilhalpando, e aí com pouco mais de profundidade, deixaremos nossas considerações a respeito para a análise da segunda peça.

Para imprimir sua marca nas comédias, Sá de Miranda integra no texto, junto aos motivos latinos e italianos, diversos provérbios e ditos portugueses. Assim avaliam muitos dos estudiosos de sua obra esta sua prática, como exemplo da criatividade do poeta. Mas lembramos que também esta não é uma prática peculiar ao poeta português. Já a Celestina, de Rojas, abusava deste artifício, assim como os italianos, em menor escala.

\subsubsection{Citações, condensações e paráfrases}

Observamos acima que Sá de Miranda evoca a Antigüidade Clássica, aludindo a suas personagens mitológicas, históricas ou da ficção. Alude também à literatura e a filosofia antiga principalmente pela voz do "doutor", citando Ovídio e Virgílio e, de outra forma, evocando Horácio. Mas quanto às comédias exemplares, limita-se quase que somente à arquitextualidade. Seu texto evoca os predecessores, aludindo a temas e motivos, situações e tipos comuns a uma grande variedade de textos da mesma tradição. Esta sua comédia caracteriza-se, deste modo, como uma montagem de fragmentos arquitextuais, muito mais do que textuais.

O diálogo intertextual mais importante é mantido com Ariosto, especialmente com a peça I Suppositi. Diferentemente de Ariosto, porém, que constrói suas comédias como "mosaico de citações", Sá de Miranda constrói um "mosaico de situações". Nestas situações, as falas das personagens são muito semelhantes às dos modelos imitados, mas não se pode precisar se são paráfrases, menos ainda se são citações modificadas ou condensadas dos textos aos quais alude. O poeta português transforma os diálogos dos modelos conforme as necessidades de seu enredo. Desta forma, o hipertexto faz lembrar o hipotexto, mas não o repete ipsis 
litteris. As citações literais resumem-se às que usa o "doutor" para caracterizar o tipo e nenhuma destas provém de qualquer comédia. Por isso, relacionaremos as passagens que nos pareceram parafrásicas.

Em Mostellaria (II, 1) encontramos um modelo de diálogo entre servo e jovem amo, que deve ter inspirado a paráfrase em Os Estrangeiros (IV, 4) sobre o motivo do retorno imprevisto do pai. Também o monólgo do servo, antes do diálogo, é parafrásico e aparece, na mesma situação, em La Cassaria (IV, 1). Nos três enredos, o pai ausente volta inesperadamente quando o imbróglio está no ápice e nada pior poderia acontecer para atrapalhar ainda mais os malfadados planos do seruus e do adulescens. Em Mostellaria, é o escravo Tranio (seruus currens) quem chega correndo do porto com a má notícia e encontra Philolaches, seu jovem senhor:

Tra.: - ... A esperança morreu, não há mais lugar para a confiança, e nem a própria Salvação poderia nos redimir, ainda que ela quisesse. Acabei de ter a mais vil das visões da desgraça e do infortúnio lá no porto! O meu senhor está de volta do estrangeiro. O pobre Tranio está arruinado! [...] Mas que idiota eu sou! Por que eu não corro para casa o mais rápido possível? [...] Philolaches!

Phi.: - O que é?

Tra.: - Você e eu, nós dois estamos ...

Phi.: - Estamos o quê?

Tra.: - Mortos!

Phi.: - Por que?

Tra.: - Seu pai voltou!

Phi.: - Quê? Eu ouvi direito? ${ }^{247}$

Em La Cassaria não há o diálogo entre o criado e o jovem senhor, mas somente o monólogo do primeiro, Volpino, que termina com a chegada inesperada do senex:

Vol.: Tantas adversidades, tantas desgraças te assaltam, mísero Volpino, de todos os cantos, que se souberes te defender, podes gabar-te de ser o melhor esgrimista que há no mundo hoje. Oh, risonha Fortuna, como estás sempre pronta para opor-te

\footnotetext{
${ }^{247}$ Versão nossa de tradução inglesa anônima. In: The Complete Roman Drama, v. 1. Edited, and with an introduction by George E. Duckworth. New York: Random House, 1942.
} 
aos nossos planos! [...] Um criado [...] me disse que o meu velho não saiu do porto, que quando estava para embarcar chegou um navio com cartas dando conta de que os negócios pelos quais ia em viagem estavam todos resolvidos e que ele não precisava mais ir. [...] Mas que luz é aquela que vem de lá? Ai de mim, que não seja o velho! Ai, infeliz! É o patrão, com certeza. Tu estás morto, Volpino! Que farás, miserável?

N'Os Estrangeiros, é Calídio quem vem correndo da "ribeira" ao encontro do jovem patrão, Amente, para dar a má notícia do retorno do pai. O monólogo lamurioso do criado tem lugar na cena anterior à do diálogo:

Cal.: - ... Folguei de me despejar deste por buscar Amente para lhe dar estas boas novas, com que haja seu conselho, que eu havido tenho o meu de apanhar os pés. Agora que fará com tal ajuda? Ai, mimosos, criados em vossos apetites, que em fim vem a ser o que não quereis crer, nem ouvir: então esmorecer! [...] A mim só cumpre buscar meu remédio, [...] bons pés tenho e arrezoada língua, do mais (como dizem) sobre a terra anda o haver.

Ame.: - Quem me chama? Ó meu Calídio, que a ti buscava eu!

Cal.: - E eu a ti!

Ame:: - Desviemo-nos, e vamos buscar algum lugar em que falemos à nossa vontade.

Cal.: - Ó Amente, à nossa vontade não podemos nós falar.

Ame.: - Porquê, Calídio?

Cal.: - Despois que me deixastes, dei comigo na ribeira, que me temia muito do mar e velava-me dele; em fim, tantas vezes fui lá, até que arrecadei.

Ame.: - E quê? Calídio?

Cal.: - Achei novas de teu pai.

Ame.: - Triste de mim! é ele morto? que assim te demudaste.

Cal.: - Tu e eu, Amente, somos os mortos, que ele vivo é e são.

Ame.: - Isso é bem.

Cal.: - E dentro de Palermo.

Ame.: - Isso é mal.

Cal.: - Não vês quam perto estava o mal do bem?

Ame.: - Contas-me tu verdade, Calídio?

Cal.: - Muito contra a minha vontade. [...] Amente, o espaço é pouco, as palavras não podem ser muitas. Teu pai bem o conheces, há de trazer suas contas repartidas em duas partes não iguais, convém a saber: a ti repreender-te, e a mim castigar-me. [...] A mim é necessário encomendar-me aos meus pés... 
Observe-se que não só o diálogo entre criado e jovem senhor é paráfrásico, mas também os monólogos dos servos, nas três comédias, têm o mesmo conteúdo semântico: os três consideram-se "mortos" e sabem que serão castigados violentamente.

No mesmo ato, mais à frente (Estr. IV, 6), quando Calídio e Amente vêem se aproximar o pai do jovem e sabem que o castigo é iminente, o diálogo que se dá entre os dois é parafraseado da comédia Phormio ( $\mathrm{l}, 4)$, de Terêncio. Nesta, falam Geta, o seruus, e o adulescens Antifão:

Geta: - ... Mas quem é aquele velho que estou a ver ao fundo da rua? É ele mesmo.

Anti.: - Não consigo ficar aqui.

Geta: - Ei! Que é que estás a fazer? Para onde vais, Antifão? Fica, fica, já disse! ${ }^{248}$

N'Os Estrangeiros,

Cal.: $-\ldots$ e vê-lo que aparece!

Ame.: - Aquele é, não posso esperar.

Cal.: - Que fazes? onde vás? torna, que eu era o que havia de fugir.

Parafrásica é também a fala de Calídio (Estr. V, 2), quando se sente injustiçado, por ter sido espancado. A mesma situação ocorre em Rudens (III, 2), com o também seruus Tracalião, e em Adelphoe (II, 1), com o leno Sanião. Todos reagem de forma semelhante frente a mesma situação:

Cal.: - Regedores, cidadãos, homens de bem, os grandes e os pequenos todos me acudi, todos me valei, que a todos releva, se aqui há algũa lembrança de liberdade e justiça!

Tra.: - Cidadãos de Cirene, imploro a vossa ajuda! Camponeses, moradores da vizinhança, amparai os desamparados e ponde um freio ao desenfreio! Dai escarmento ao despudor e prêmio à pudicícia ... ${ }^{249}$

\footnotetext{
${ }^{248}$ Tradução de Aires Pereira do Couto. Lisboa: Edições 70, 1999.

${ }^{249}$ Tradução de Jaime Bruna. PLAUTO. Comédias: O cabo / Caruncho / Os Menecmos / Os prisioneiros / O soldado fanfarrão. São Paulo: Cultrix, 1978.
} 
San.: - Eu vos conjuro, gentes desta terra!... Acudam a um desgraçado, a um inocente!... Ajudem um pobre desvalido!... ${ }^{250}$

Earle lembra que, na comédia latina, "ocorre às vezes, embora raramente, o castigo de um escravo ou de um alcoviteiro", mas julga que na comédia mirandina a violência é maior, assim como maior é "a dor do castigado, que produz nele uma mudança de personalidade. ${ }^{251}$ Pensamos que a diferença está no comportamento das personagens e não no castigo e na dor maior ou menor em uma que na outra. Em Andria, por exemplo, o seruus Davo, quando é punido, na mesma situação que é Calídio n'Os Estrangeiros, conta com o compadecimento do adulescens que pede ao pai para livrá-lo do castigo. O seruus acaba por comprazer-se na reconciliação de pai e filho. Amente, ao contrário, abandona Calídio à própria sorte, o que o torna hostil. O exagero de escravos e alcoviteiros ao alardear a dor e a injustiça que julgam terem cometido contra eles é o mesmo nesta comédia e nas precedentes, como se pode notar pelos trechos citados logo acima. Isto não nos parece mais do que uma das alterações do topos que Sá de Miranda vem tentando imprimir ao longo de sua comédia, como maneira de ser criativo.

É difícil afirmar que uma passagem é paráfrase, ou que não é, de determinado hipotexto, posto que a múltipla contaminação remete a mais do que um texto e que, como dissemos antes, os textos latinos eram compostos em versos e estes, muitas vezes, eram condensados na transposição para a prosa. As modificações nas tramas - que são novas, pois não se trata de tradução, mas de reelaboração de textos - e as alterações dos topoi, como forma de reproduzir criativamente os modelos, implicam na modificação também do texto. Assim, podem ter passado despercebidas para nós as condensações de textos que incluíam certas modificações e alterações que o autor, pela necessidade do novo texto, a ele imprimiu . O que se pode afirmar é que, para situações semelhantes, quase sempre, correspondem falas semelhantes às do(s) modelo(s). Isso nos traz à memória o

\footnotetext{
${ }^{250}$ Tradução de Walter de Souza Medeiros. TERÊNCIO. Os dois irmãos. Coimbra: Instituto Nacional de Investigação Científica/Centro de Estudos Clássicos e Humanísticos da Universidade de Coimbra, 1983.

${ }^{251}$ Traição e Amargura nas comédias de Francisco de Sá de Miranda, op. cit., p. 92-93.
} 
segundo princípio dos cinco arrolados por Russel para a imitação bem sucedida: "Deve-se reproduzir o espírito mais que a letra." Se esta foi a intenção do autor, podemos dizer que Os Estrangeiros é uma imitação bem sucedida.

Não foram encontradas nem auto nem intratextualidade nesta obra. Quanto à paratextualidade, não é possível afirmar que a intenção do autor ao dar à sua comédia o títlulo Os Estrangeiros foi evocar diversos títulos exemplares no plural, como Captivi (Os prisioneiros) e Adelphoe (Os irmãos) de Plauto, I Suppositi (Os trocados, que seria uma tradução possível para esse título ainda sem versão para o português) e Gli Studenti (Os estudantes) de Ariosto, pois seria este um argumento fraco e a hipótese careceria de informações mais substanciais que a comprovassem; não as encontramos no texto, nem o autor deixou qualquer nota a esse respeito. Apontar para um paralelismo com os títulos das comédias de seus predecessores, não pode, desse modo, ser mais que uma suposição.

\section{Os Vilhalpandos}

\subsection{Da peça}

Curiosamente, é nesta comédia representada em 1538, tempos depois de se afastar da corte, dez anos após a primeira representação d'Os Estrangeiros e onze depois de sua volta da Itália, que Sá de Miranda vai criticar de forma mais mordaz a degradação moral dos romanos. Lembremos que o conservador e austero Sá de Miranda, em 1521, ${ }^{252}$ quando deixou um Portugal tradicionalista, que vivia sob o dogmatismo católico, foi encontrar uma Itália paganizada, de costumes degradados, além de arrasada pelas lutas e invasões que tiveram início em 1494, com a reivindicação de Carlos VIII, da França, de seu direito de sucessão em Nápoles e Milão. Em 1521, justamente quando o poeta chega à dividida Itália, esta situação se agravara com a rivalidade entre Francisco I e Carlos V. Nessas disputas por

${ }^{252}$ Ou antes, se comprovada a hipótese de Earle. 
aumento de poder envolveram-se reis e papas, com acordos e traições. É, pois, notável que os temas da degradação dos costumes e da corrupção do clero tivessem sido abordados somente de passagem na primeira comédia, quando a motivação à crítica deveria ser maior, pela proximidade em relação aos acontecimentos, e só viessem ganhar força nesta segunda, num momento em que a Inquisição já havia sido instaurada em Portugal.

Como quanto à composição da primeira comédia, Earle acredita que também Os Vilhalpandos tenha sido escrita enquanto o poeta vivia na Itália. Contudo, o próprio estudioso admite que, até hoje, "nenhuma evidência veio a luz" sobre isso. ${ }^{253}$ Alegando que Sá de Miranda não faz nenhuma referência na comédia ao saque de Roma, busca comprovar sua hipótese. Mas há, sim, referência a esse evento em I, 3 e III, 5. Admitindo que a referência existe, Earle continua defendendo sua hipótese, alegando que a peça pode ter passado por revisão depois de $1527,{ }^{254}$ e quanto às referências que o poeta faz no prólogo à conquista de Túnis, em 1535, e ao cerco de Diu pelos turcos, em 1538, sua justificativa é que o prólogo pode ter sido escrito depois, por ocasião da representação da comédia. É possível, mas permanece o fato de que, da mesma forma que no caso d'Os Estrangeiros, também para Os Vilhalpandos não há qualquer documento que comprove a data de sua composição.

Surpreende que esta comédia não tenha sofrido a censura eclesiástica à época - viria a sofrer mais tarde, depois da morte do protetor do poeta, D. Henrique, em 1580. Segundo Remédios, "ao tempo a censura não tinha o rigor que se lhe supõi e depois veio a ter." 255 Mas Earle lembra que o cardeal, "na segunda metade do século XVI, [...] foi responsável por diversos índices de livros em português proibidos. Entre estes estavam um número de textos de peças, embora nenhum de Sá de Miranda". ${ }^{256}$ Possivelmente, a ambientação de suas peças na Itália preveniuas contra a censura.

Sá de Miranda estava ciente de que suas peças não chegavam a ser imorais e não representavam mais do que a vida que assistira na Itália. Mesmo assim, temia a censura inquisitorial, tanto que se justifica e pede o amparo de D. Henrique na

\footnotetext{
${ }^{253}$ Sá de Miranda's Roman Comedy, op. cit., p. 156.

254 Ibidem, p. 157.

255 Op. cit., p. 1053.

${ }^{256}$ Sá de Miranda's Roman Comedy, op. cit., p. 162.
} 
dedicatória que acompanhou sua primeira comédia, e que se repetiria na segunda, dirigindo a mesma carta a D. Duarte. ${ }^{257}$ Seu temor pode ser melhor avaliado na versão manuscrita:

... o de que sempre houve medo foram más interpretações a que se não pode fugir em nenhũa maneira, tanto que os hereges, interpretando mal, todos querem fundar seus erros na sagrada escritura e o diabo também. A isso houvera dous remédios: não escrever e dormir meu sono em cheo e o milhor é o segundo, pois já não podia dormir como Horácio diz: fora romper ou queimar tudo. ${ }^{258}$

O poeta português temia que suas críticas fossem tomadas a sério e não como imitação das críticas feitas pelos comediógrafos italianos. Além disso, sabemos que o cardeal tomou sua crítica como voltada à sociedade italiana, não à portuguesa. Ainda assim, o poeta teve medo da má interpretação, como a que os hereges fazem da bíblia. Mas, se pensarmos na situação de Sá de Miranda no momento em que traz à luz Os Vilhalpandos, não funcionaria essa imitação como alegoria para criticar os próprios costumes portugueses? Lembremo-nos de que quatro anos após sua volta da Itália, o poeta abandona a corte, onde fora sempre prestigiado antes da viagem e bem recebido de regresso - era amigo de Dom João III, que até mesmo o convidara para ser conselheiro na corte, e tinha como mecenas Dom Henrique - e se isola em sua quinta no Minho - fora buscar, como Horácio, o otium e a aurea mediocritas? Pensamos que não. Estaria, talvez um tanto contrariado com os rumos que tomava o país: “... no seu retiro minhoto, assistia confrangido aos males do país e lhe profetizava tam lucidamente a ruína...", comenta Rodrigues Lapa. ${ }^{259}$ Não é certo que tenha havido qualquer intriga ou desafeto que o levasse a se afastar da corte, mas o fato é que, de longe, escreveu esta comédia repleta de críticas, como observador da corte, não como cortesão.

Sá de Miranda situa suas comédias num lugar e numa época próximos de seu tempo e de seu espaço e, trazendo a ação para um contexto mais próximo, pode

\footnotetext{
${ }^{257}$ No trabalho citado, de Marcia Arruda Franco, sobre as duas versões da dedicatória, a professora informa que houve quatro cópias da versão manuscrita, três delas dirigidas a Dom Duarte, dedicandoIhe a comédia Os Vilhalpandos.

${ }^{258}$ Edição de Marcia Arruda Franco.

${ }^{259}$ Op. cit., p. VII.
} 
tanto tornar seu enredo mais acessível à compreensão do público, como pode tornálo ambíguo, gerando má interpretação. Na comédia latina, que era uma adaptação da véa grega, isso não acontecia. Elas eram as mesmas comédias gregas com a linguagem adaptada ao latim. Usava-se, muitas vezes, inserir versos que fizessem menção a alguma coisa significativa do tempo e do local onde a comédia era representada, como o anacronismo de efeito cômico, já apontado no capítulo anterior, da alusão de Plauto, no Anfitrião, à "polícia noturna" de Roma. O que Sá de Miranda fez não foi simplesmente inserir alusões a acontecimentos ou elementos significativos para os portugueses numa versão de uma comédia latina. Ele criou uma comédia nova, com situações próprias do mundo contemporâneo, parafraseando comédias latinas e italianas. Impõe-se-nos, assim, a consideração de que, ao sentir-se amparado pelas amizades que mantinha na corte, Sá de Miranda ousou elevar a voz, ainda que sob a máscara da imitação, contra uma sociedade que se entregava aos vícios da cobiça e da luxúria - que cresciam juntamente com a riqueza gerada pela expansão do reino -, usando uma crítica imitada dos italianos em causa própria.

A comédia Os Vilhalpandos teve duas edições em 1560 (as primeiras), ambas de António de Maris, sem que tenha havido qualquer alteração no texto. A única diferença é que uma foi impressa em caracteres redondos e a outra em carcteres góticos, como informa Remédios. ${ }^{260} \mathrm{O}$ fenômeno indica que a peça teve grande aceitação naquela época e que foi apreciada por muitos além de seu patrocinador, o cardeal D. Henrique.

\subsection{Do jogo alusivo - o diálogo intertextual}

\subsubsection{A arquitextualidade}

Da mesma forma que n'Os Estrangeiros, na comédia Os Vilhalpandos encontramos as marcas que refletem sua relação arquitextual com o gênero cômico:

${ }^{260}$ Op. cit., p. 1042. 
a divisão da comédia em prólogo e cinco atos, o retratar-se a vida comum, a reprodução de lugares-comuns, fórmulas, convenções, temas e tipos da comédia palliata, assim como sua ambientação numa cidade estrangeira - agora a ação transcorre em Roma, na Itália como a ação da primeira, confirmando sua intenção de imitar o conjunto de textos cômicos italianos. Também a composição em prosa evoca este conjunto, marca já registrada na primeira comédia.

A presença numa mesma comédia dos tipos miles, parasitus, meretrix e lena, além dos serui, pode indicar que estamos diante de uma comédia de enganos e, como costuma ser esta categoria de comédias, de muita ação, portanto, deveria tratar-se de uma fabula motoria. Mas não é isso o que encontramos no texto: o ritmo permanece lento como o d'Os Estrangeiros, os tipos carecem da energia própria à sua caracterização e o enredo tropeça na multiplicidade de motivos.

Sá de Miranda traz n'Os Vilhalpandos toda uma galeria de tipos da comédia latina. Há, além dos citados acima, o senex iratus - Pompónio, o velho ranzinza - e o senex indulgens - Mário, o complacente - a evocar, principalmente, a dupla Simão e Cremes, de Andria, mas também Micião e Demea dos Adelphoe e tantos outros pares de velhos. Pompónio carrega uma marca comum a muitos senes da comédia latina, a misoginia, que se vê, por exemplo, em Heautontimorumenos, de Terêncio, em Menaechmi e Rudens, de Plauto. E para fortalecer esta característica do senex iratus, o poeta dá lugar também à matrona, que faz por justificar a misoginia do marido, como ocorre na plautina Asinaria.

O seruus currens, que é mais comum em Plauto, mas aparece também em Terêncio (Adelphoe), é um tipo que, como sua denominação diz, corre. Tem muitas vezes características também do callidus. N'Os Vilhalpandos cumpre seu papel de correr, mas é um tipo um tanto apático para um caráter que deveria ser mais vivo. Talvez Sá de Miranda não desejasse imprimir aquele caráter ladino, próprio dos serui das comédias latinas, nesta figura de sua peça. Na própria fala do criado Antonioto (I, 4), ao evocar os famosos serui Davo (Andria, Phormio) e Siro (Adelphoe, Heautontimorumenos), transparece essa intenção do autor:

Ant.: - ... Oh! que inveja hei tamanha àqueles Davos e Sírios das comédias, que tam bons Ihe serão de enganar os seus velhos babosos! 
Mesmo assim esses tipos estão aí, evocando uma tradição, evocando um conjunto de textos do gênero cômico.

Comparecem ainda os adulescentes, carregando sua marca patética, como o fazem na maioria das comédias precedentes. Estes evocam, em especial, Carino e Pânfilo de Andria.

Os motivos desta comédia provêm de uma grande variedade de textos do gênero. O motivo central é o da paixão do jovem por uma meretriz, muito comum nas comédias latinas; para citar somente algumas, está presente em Eunuchus, Bacchides, Mercator, Miles gloriosos. Mas a situação em que se coloca - a meretriz é filha de uma lena que vende seus favores a quem melhor pagar por eles, e, estando o rapaz sem dinheiro, é preterido - parece anunciar o modelo-exemplar do poeta: a Asinaria, de Plauto.

Contudo, o que salta aos olhos logo no título da peça - e este, sim, diferentemente do que ocorre com o título Os Estrangeiros, trava uma relação paratextual com uma série de títulos semelhantes, envolvendo duplos de mesmo nome (Os Menecmos, As Báquides) - é o tema dos simillimi, dos iguais, que, desde a Antigüidade até hoje, vem inspirando autores e rendendo enredos a inúmeros filmes, peças e novelas. Não há no texto nenhuma indicação de que haja semelhança física entre os dois Vilhalpandos, como há entre os dois Menecmos e as duas Báquides, mas parece que a idéia do autor ao dar às duas personagens o mesmo nome, a mesma profissão e a mesma nacionalidade foi a de evocar a confusão causada pela aparência igual que anima as plautinas Menaechmi, Bacchides e Anphitruo - o que resulta, nas palavras de Duckworth, em "uma das mais efetivas fontes de riso na comédia de todos os tempos"261 - e não apenas aludir ao tema dos duplos, que não são necessariamente sempre semelhantes na aparência. A alusão é direta e sabemos, já pelo título, que é nessas peças que ele vai buscar, pelo menos, algum dos motivos de sua comédia.

Além de evocar elementos comuns a vários textos cômicos, filiando-se, assim a esta tradição, como fez na primeira peça, também nesta Sá de Miranda vai

${ }^{261}$ DUCKWORTH, George E. The Complete Roman Drama. New York: Random House, 1942, p. 437, v. 1. 
imprimir marcas que o identifiquem com toda a cultura clássica, aludindo várias vezes ao mundo antigo. Na fala de Fabiano, faz lembrar a Roma antiga, sua fundação, referindo-se ao rapto das Sabinas, e todo seu poder, para então acabar na decadência em que se encontra no momento presente (IV, 1):

Fabiano: $-\ldots$ que senhoreou esta sua terra o mundo todo, que não o que lemos dela, nem o que vemos desses seus teatros, termas, arcos triunfais [...]. Oh! torpezas, oh! descaimento daquele sangue Romão, que tam caras comprou as suas Sabinas!

Nomes de famílias ilustres daquela Roma poderosa vêm também ilustrar o texto $(I, 1)$ :

Pompónio: - ... Ao menos, dos nossos mancebos romãos, os Brutos e os Décios morrem-se pola repúbrica.

E também seus sábios são evocados (IV, 5):

Vilhalpando: - Falas como um Sêneca.

Alude à Eneida ao comparar uma travessia pela Roma atual à descida de Enéias ao Hades (I, 3):

Milvo: - ... se me houveres mester buscar-me, e seja como deve, que não percamos tempo agora.

Antonioto: - De que maneira?

Milvo: - Com aquele ramo com que Eneas passou todos os perigos do inferno.

E lembra ainda o herói Orlando, de Ariosto, na adulação do parasita ao soldado fanfarrão:

Milvo: - Um Rolão! 
Aproveitando-se de uma situação em que pode inovar, une a tradição portuguesa à cultura clássica, fazendo o soldado espanhol Vilhalpando aludir a Hércules e Júpiter numa esparsa de tradição bem ibérica:

$$
\begin{aligned}
& \text { Vil.: - Hércules que la serpienta } \\
& \text { Hidra mata sin temores } \\
& \text { tuvirera gran sobrevienta } \\
& \text { de nos requestar d'amores. } \\
& \\
& \text { Jupiter el falso Diós } \\
& \text { amor transformado em toro, } \\
& \text { amor transformado em oro, } \\
& \text { como agora a mim por vos. }
\end{aligned}
$$

E como a marcar sua condição de cristão, depois de aludir a símbolos do paganismo, faz uma citação da epístola de São Paulo aos Efésios $(\mathrm{l}, 1)^{: 262}$

Mário: - Porque aquele conselho santo, o qual nós tam mal cumprimos, que se não ponha o sol sobre a nossa ira, estes o cumprem bem.

A arquitextualidade desta comédia relaciona, deste modo, o texto Os Vilhalpandos com as tradições genérica, cultural e também religiosa a que o autor busca se vincular.

\subsubsection{A supercontaminação}

Ambientar a ação da peça em Roma, cidade invadida por soldados estrangeiros e por maus costumes, dá chance ao autor de desenvolver o tema da degradação moral desta civilização - que é também a dele. O tema é, como já observamos, imitado da comédia italiana e já fora reproduzido em sua primeira

\footnotetext{
${ }^{262}$ IV, 26: "Se vos irardes, seja sem pecar; não se ponha o sol sobre a vossa ira". Em nota do editor.
} 
comédia, mas se fortalece n'Os Vilhalpandos. A retomada do miles como soldado invasor - que já figurara entre os tipos d'Os Estrangeiros e agora tem um papel de maior destaque - e a presença do tipo meretrix, a desvirtuar rapazes de família, reforçam a idéia de uma sociedade falida, de costumes degenerados. $E$ a inclusão de mais um tipo tomado à comédia erudita italiana, o "ermitão", espécie de nigromante que aparece para incentivar as práticas supersticiosas a que se entregava a sociedade, vem reiterar o propósito crítico do autor de levantar questões de seu tempo. Com este tipo evoca II Negromante de Ariosto e também a Calândria de Bibbiena. Também os "físicos", sobre os quais conversam os velhos na primeira cena da peça, aludem ao falso médico da maquiavélica Mandrágora.

No cenário vemos três casas, as dos dois velhos amigos Pompónio e Mário e a de uma meretriz bolonhesa, Aurélia, em frente às quais vemos desenrolar um enredo confuso, por conta da multiplicidade de motivos e da intriga tripla mal desenvolvida (que, aparentemente, serviu apenas para que o autor se exercitasse na imitação "em segundo grau"). Torna-se difícil até mesmo resumir o enredo, tão confuso é, mas vamos a isso: o jovem Cesarião, comprometido com a filha de um amigo de seu pai, enamora-se de uma meretriz, por quem é recebido durante algum tempo, mas é preterido, por falta de dinheiro, em favor de outra pessoa que possa pagar por seu amor. O soldado Vilhalpando faz um contrato de exclusividade dos serviços da moça com sua mãe proxeneta, tendo a intermediação do "alcoviteiro" Milvo, ${ }^{263}$ que o engana para favorecer os amores da meretriz com outro soldado de mesmo nome. Fabiano, amigo de Cesarião, ama perdidamente Hipólita, a noiva do amigo, e pensa que está sendo traído por ele - Cesarião jurava não desejar se casar com a noiva arranjada - depois de ouvir uma conversa em que conhece ser o casamento certo. Por fim, Cesarião percebe a volubilidade da meretriz e decide casar-se com Hipólita, ao mesmo tempo que descobre ser Fabiano, na verdade, o irmão dela que tinha desaparecido quando criança. Ao soldado, é restituído o dinheiro pago pelos serviços não prestados da meretriz, enquanto a mãe proxeneta é punida.

\footnotetext{
${ }^{263}$ Milvo carcteriza-se como parasitus muito mais do que como alcoviteiro, mas como tal é denominado pelo autor.
} 
A intriga dupla é comum na comédia latina devido à contaminação que se dá em quase todas as peças. Os motivos do contrato e do jovem apaixonado pela meretriz e sem dinheiro para gozar desse amor já formavam uma intriga dupla na Asinaria. Ariosto faz uso do segundo destes motivos em La Lena, "contaminando" somente a protagonista com características da alcoviteira Celestina, da peça de Fernando de Rojas, mas o enredo é totalmente diferente. Uma intriga múltipla como esta d'Os Vilhalpandos, na comédia latina, não é de nosso conhecimento. O que Sá de Miranda parece ter tentado fazer foi uma montagem de fragmentos, como a que Ariosto fez em La Cassaria e I Suppositi, e que ele mesmo já experimentara n'Os Estrangeiros com melhor êxito, sem abusar de paráfrases e citações. Mas, desta vez, não foi feliz no resultado final. Ariosto, apesar das inúmeras citações das mais diversas comédias, compõe suas comédias com uma única intriga. Sá de Miranda perdeu-se na amarração dos diversos motivos e diálogos parafraseados.

Ao separarmos as intrigas, percebemos que cada uma delas poderia gerar uma comédia diferente e inédita:

Primeira intriga: rapaz enamorado de uma meretriz é preterido por não ter meios para mantê-la como amante. Seus pais tentam por meios diversos afastá-lo da casa dela, pois um casamento de conveniência já havia sido arranjado trabalhos inúteis e sem sentido, desde que a mãe alcoviteira da meretriz já decidira não mais recebê-lo, dando preferência àquele que pudesse melhor pagar por seus préstimos, no caso, um soldado fanfarrão. Reconhecendo a volubilidade da meretriz, o rapaz decide obedecer ao pai e casar-se com sua escolhida. $\mathrm{Na}$ base dessa primeira intriga encontram-se a Asinaria, de Plauto, e La Lena, de Ariosto, no que diz respeito ao rapaz sem recursos preterido pela alcoviteira, que tem o domínio sobre sua amada, mas a disputa pelo amor da meretriz aparece também em Terêncio, no Eunuchus. Terêncio dá ainda o mote, através da Hecyra, do rapaz apaixonado pela meretriz que se vê obrigado pelo pai a se casar com a filha do vizinho, assim como na Andria, com a diferença que nesta última a moça não é meretriz - embora seja considerada como tal pelo pai do rapaz - e sim uma jovem pobre. Quanto à decisão do filho de abandonar a meretriz para fazer um casamento de conveniência, encontramos o motivo em Heautontimorumenos, também de Terêncio. Vemos que, 
se a partir dos motivos desta primeira intriga de Os Vilhalpandos fosse construída uma comédia nova, esta já seria fruto de contaminatio e de múltipla intriga.

Segunda intriga: um certo capitão espanhol chamado Vilhalpando, soldado fanfarrão, faz um contrato com a mãe da meretriz, por intermédio de um alcoviteiro, para ter a exclusividade dos serviços da moça. Porém, a meretriz enamora-se de um outro Vilhalpando, também soldado espanhol, e pede que o alcoviteiro Milvo, seu amigo, Ihe traga este último no lugar do primeiro, pedido a que ele atende. Não conhecendo o Vilhalpando do contrato, a mãe alcoviteira deixa entrar em casa o preferido da filha. Quando chega o primeiro Vilhalpando, ela não lhe abre a porta. Depois de muita discussão, Milvo consegue, através de suas artimanhas, tirar da velha o dinheiro pago antecipadamente e restituí-lo ao soldado fraudado. O motivo do contrato está na Asinaria; o das fanfarronices do soldado, principalmente, no Miles gloriosus, de Plauto, mas comparece também no Eunhchus de Terêncio e nas plautinas Poenulus, Curculio e Bacchides. E há, ainda, o tema dos simillimi - uma cena inteira é absorvida dos Menaechmi de Plauto. Outra vez, vemos que uma única comédia desenvolvida a partir do tema dos simillimi e de vários motivos já seria obra inédita a partir da contaminatio.

Terceira intriga: o jovem Fabiano ama devotamente Hipólita, moça prometida em casamento a seu amigo Cesarião, que ama outra mulher e foge do casamento arranjado. Um engano promovido pelos velhos, pais de Cesarião e da moça, leva Fabiano a pensar que o casamento é certo e que o amigo é um traidor. Reconhecido, no final, como o filho do pai da moça a quem ama, desaparecido numa viagem de navio quando criança, sendo, portanto, irmão dela, aceita, de bom grado, casar-se com a irmã do amigo Cesarião, enquanto este, obedecendo ao pai, vai casar-se com Hipólita. Da Andria, de Terêncio, Sá de Miranda importa o motivo do jovem que ama a noiva do amigo. Os outros motivos, já foram identificados na primeira intriga. Teríamos mais um produto de contaminatio, numa comédia nova baseada nestes motivos.

A terceira intriga amarra-se à primeira, mas não tem nenhuma ligação com a segunda. Vem para ajudar na conclusão da trama, mas não seria indispensável. Porém, sem ela, a comédia de Sá de Miranda soaria como uma reprodução da 
Asinaria - apesar de todas as inserções de motivos e citações de outras comédias e não como uma comédia inédita.

Somando-se aos temas arrolados os temas contemporâneos - das superstições, da corrupção na Igreja, da degradação dos costumes - temos uma verdadeira miscelânea. A contaminatio é uma técnica de composição utilizada desde a Antigüidade e que se torna regra nas composições clássicas, inclusive em sua forma ampliada, a supercontaminação. Todavia, ela não deve deixar marcas. As múltiplas intrigas resultantes da contaminação precisam ser muito bem amarradas para que o resultado final, a comédia inédita, tenha sentido. A transparência da "contaminação", ou seja, das alusões a diversos textos, deve ter como propósito suscitar um sentido novo através do reconhecimento das fábulas evocadas e seus respectivos contextos.

A propósito do reconhecimento, sabemos que muitas situações se repetem em comédias diversas. A disputa entre um jovem e um soldado pelo amor da meretriz, por exemplo, é motivo em Plauto, na Asinaria, e também em Terêncio, no Eunuchus. Como reconhecer qual delas nosso autor quis evocar? A caracterização dos tipos é diferente nos dois autores latinos. O miles é sempre stultus, mas as meretrices dos dois poetas latinos apresentam características diferentes: a meretrix de Terêncio tem uma atitude nobre, é generosa, o que faz com que o rapaz e seus familiares a tratem com respeito; a de Plauto costuma ser mesquinha. Em Sá de Miranda encontramos uma meretrix mesquinha e mentirosa - de caráter ainda pior do que o da plautina -, o que leva o rapaz a desprezá-la. Além disso, na Asinaria, a meretrix encontra-se em situação semelhante à d'Os Vilhalpandos, tem uma mãe alcoviteira que quer vender os favores da filha àquele que tiver mais bens a oferecer, tentando afastar de sua casa o jovem apaixonado de poucos recursos. Com todas estas semelhanças, neste caso, só poderia remeter ao texto plautino. Mas há uma diferença na caracterização do senex. Sá de Miranda despreza o senex puerilis, pai do adulescens da Asinaria, que não só ajuda o filho a conseguir seu intento de gozar da companhia da meretrix, como participa ele próprio da orgia. Em seu lugar, o poeta coloca um senex iratus, que desaprova a insensatez do filho. Tudo termina como manda a moral e os bons costumes: os maus são punidos, a obediência ao pai é um valor restituído e, sem discutir, o filho aceita o casamento contratado, 
exatamente como no Heautontimorumenos. Final bem terenciano. O que começou como uma tentativa de fabula motoria, acaba como fabula stataria, inclusive com o reconhecimento no final do filho desaparecido de outro velho.

Em tempos de degradação moral, tema recorrente no Renascimento, parece proposital que o poeta busque perverter ainda mais um tipo que por si só já é de natureza perversa - as meretrizes têm consciência de que o que os jovens amam nelas é sua beleza, que é efêmera, então, entre o amor e o dinheiro, optam sempre pelo último (mesmo a meretriz de Terêncio, embora de bom coração, pensa dessa forma). Parece-nos que a intenção do autor ao tomar a meretriz plautina e o velho terenciano seja mostrar sua insatisfação com os valores adotados pela sociedade de sua época e mostrar como os costumes podem se regenerar.

Mesmo o parasita Milvo, a quem Sá de Miranda contamina com traços de alcoviteiro - uma contaminação de tipos como a que fez Ariosto com a personagem Lena, mistura de meretrix e lena -, tem seu paradigma em Terêncio e não no parasitus da Asinaria: o parasita Formião (Phormio). Até o nome que the cabe vem da comédia terenciana. Como observa Earle, a origem do nome Milvo está na ave de rapina chamada milhafre, à qual se compara Formião (II, 2). A tradução de milhafre em latim é miluus. ${ }^{264}$

\subsubsection{Citações, condensações e paráfrases}

Além da retomada de temas e tipos de variadas comédias precedentes pela técnica da contaminatio, o processo criativo da imitatio permite a reprodução de versos, de falas e até de diálogos inteiros. Sá de Miranda, n'Os Vilhalpandos, aproveitando-se dessa liberdade, experimenta compor à maneira de Ariosto, citando e parafraseando, principalmente, a Asinaria, mas também outros textos, a começar pelo prólogo.

Colocar uma personagem alegórica para apresentar o prólogo é próprio de Plauto: o deus Lar, na Aulularia; o deus Auxílio, na Cistellaria; a Luxúria, no

${ }^{264}$ Traição e Amargura nas comédias de Francisco de Sá de Miranda, op. cit., p. 93. 
Trinummus. N'Os Vilhalpandos, "a Fama faz o prólogo" e é, justamente, num destes três prólogos de Plauto, apresentados por personagens alegóricas, o de Trinummus, que Sá de Miranda vai buscar uma paráfrase, indicando que seu prólogo é conforme à tradição plautina:

\section{Trinummus:}

Luxúria: Mas não esperem que eu thes dê o enredo desta peça; os velhos que aparecerão no palco revelarão a estória a vocês. ${ }^{265}$

Vilhalpandos:

Fama: Sôbre êste negócio sairão a vós logo estes velhos ...

As primeiras falas da peça vêm na voz dos velhos Pompónio e Mário (I, 1), aludindo aos velhos Simão e Cremes de Andria (III, 3), Alcésimo e Lisídamo de Casina (III, 4) e à dupla Demea e Micião de Adelphoe (I, 2):

\section{Vilhalpandos:}

Pompónio: - Boa seja a vinda, Mário que em tua busca ia.

Mário: - Ó Pompónio, e eu na tua ...

Andria:

Cremes: - Oh, andava mesmo à tua procura!

Simão: - E eu à tua: chegas mesmo à propósito. ${ }^{266}$

Casina:

Alcésimo: ... Oh! Lisídamo, ia justamente a tua casa te procurar.

Lisídamo: Oh! E eu a tua. ... ${ }^{267}$

Adelphoe:

\footnotetext{
${ }^{265}$ Tradução nossa da versão em inglês de George E. Duckworth, op. cit., v. 2, p. 43.

${ }^{266}$ TERÊNCIO, A moça que veio de Andros. Introdução, versão do latim e notas de Walter de Medeiros. Coimbra: I.N.I.C., 1988, p. 93.

${ }^{267}$ Tradução nossa da versão em espanhol de Mercedes Gonzáles-Haba. PLAUTO. Comedias. Madrid: Gredos, 1992, p. 373.
} 
Demea: - Ah, mesmo na hora!... Andava exactamente à tua procura. ${ }^{268}$

(a continuação do diálogo, com a fala de Micião, difere dos demais exemplos)

Esta citação, com pequenas modificações, aparece tantas vezes nas comédias antigas que nos parece uma espécie de fórmula, mas a cena toda entre os velhos de Andria é tão semelhante a esta d'Os Vilhalpandos, que julgamos que o autor quis mesmo evocar o texto terenciano, anunciando já nas primeiras falas o seu modelo ou melhor, um de seus modelos - pelo menos para uma das inúmeras situações da comédia, a que envolve a terceira intriga, ligada à primeira. Os velhos de Andria armam o mesmo engano para o jovem desta peça que armarão os da peça mirandina, aquele engano que fará Fabiano acreditar na traição do amigo: fingem que o casamento entre o filho de um e a filha do outro está acertado. Também nesta comédia terenciana está presente a dupla de adulescentes e toda a situação é muito semelhante: um ama a noiva do outro.

O ato II d'Os Vilhalpandos inicia-se com um monólogo de Cesarião revoltado por não ser recebido na casa de sua amada Aurélia. Na cena seguinte, trava-se uma discussão entre ele e Guiscarda, a mãe proxeneta. O mesmo acontece no ato I de Asinaria: na segunda cena está o monólogo do apaixonado Argiripo, com o mesmo tipo de lamentação por não ter sido recebido e, em seguida, tem lugar uma discussão entre ele e Cleéreta, a lena, mãe de sua amada. Os dois diálogos são semelhantes, discute-se o mesmo assunto - o rapaz deseja saber por que não é mais recebido na casa das duas. Há ainda um trecho destas cenas em que são reconhecidas citações compondo o diálogo:

\section{Vilhalpandos:}

Ces. : - Que fez de quanto te dei?

Guis.: - É gastado; ...

\section{Asinaria:}

Arg.: - Ubi illaec quae dedi ante? (“Onde está o que te dei antes?") 269

\footnotetext{
${ }^{268}$ Tradução de Walter de Souza Medeiros, op. cit., p. 48.

${ }^{269}$ Para as passagens em que verificamos citação literal, ou seja, tradução literal, achamos por bem apresentar o texto latino, a fim de permitir uma melhor comparação.
} 
Cle.: - Abusa ... (particípio de abutor, Sá de Miranda traduziu literalmente: "é gasto, é consumido.")

Um monólogo do tipo seruus precede estas duas cenas mencionadas n'Os Vilhalpandos. Na Asinaria, um monólogo semelhante tem lugar depois das cenas mencionadas. Nesta última é Líbano, na primeira é Antonioto que aparece só, dando início à fala, ambos da mesma forma: a personagem solta uma interjeição e em seguida dirige-se a si mesma:

Vilhalpandos:

Antonioto: - Oh! doudinho de Antonioto ...

Asinaria:

Líbano: - Hercle uero, Libane ... (“Por Hércules, Líbano ...”)

Esse tipo de monólogo do seruus, iniciando com uma interjeição e conversando consigo mesmo, chamando-se pelo nome, aparece em muitas outras comédias latinas além da Asinaria, por isso, consideramos que seja uma expressão formular como tantas outras. Mas a citação literal da Asinaria, no exemplo anterior, declara que a peça plautina é um dos modelos do autor, juntamente com a Andria, para a primeira das intrigas.

Outro tipo presente nestas mesmas comédias e na mesma situação é o que na comédia mirandina é denominado alcoviteiro, mas que tem mais características do tipo parasitus, como o da Asinaria e o do Phormio, do que do tipo leno. É ele quem escreve o contrato de exclusividade dos serviços da meretriz entre 0 interessado na moça e a mãe desta. N'Os Vilhalpandos, a cena do contrato é a 5 do ato IV; na Asinaria, é a cena 1, também do ato IV. Em ambas as cenas o diálogo entre o contratante e o alcoviteiro começa pela fala do contratante. Na primeira peça é o capitão Vilhalpando, na segunda, o jovem Diabolus:

Vilhalpandos:

Vil.: - Ora vejamos este contrato $\ldots$ 
Asinaria:

Dia.: - Agedum istum ostende quem conscrips[is]ti sungrapum ... (“Ora vamos, mostre essa composição que escreveste..."270)

Segue-se a apresentação do contrato - n'Os Vilhalpandos por Milvo, na Asinaria pelo parasitus - em passagens parafrásicas do modelo, de conteúdo semelhante, e citações com modificações mínimas ou traduzidas literalmente do latim:

Milvo: - "Não terá a dita senhora Aurélia aqueles dias amigo, ainda que seja de boa amizade, nem parente, ainda que seja irmão."

Parasitus: - Alienum | hominem | intro mittat neminem. Quod illa aut amicum | aut patronum nominet ... ("Que não entre nenhum outro homem em sua casa. Nem que diga que se trata de um amigo ou seu protetor ...")

Milvo: - "Remoques nem palavras com dous entenderes."

Parasitus: Neque ullum uerbum faciat perplexabile ... ("Ela não dirá palavras de duplo sentido ...")

Milvo: — "Nem lhe virão cartas de sua terra."

Parasitus: - ... ne epistula quidem ulla sit in aedibus ... ( “... não terá em casa carta alguma ...")

Toda a cena do contrato n'Os Vilhalpandos é baseada na mesma cena da Asinaria. Mas o motivo do contrato na Asinaria não é relevante, é só um meio de levar ao desenlace: por conta do não cumprimento do contrato, o despeitado

\footnotetext{
${ }^{270}$ A palavra "sungrapum" não consta nos dicionários de latim que consultamos. No de grego,

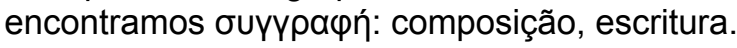


Diabolus faz com que a mulher do velho conheça o despudor do marido. $O$ argumento da peça latina apresenta o velho pai que quer ajudar o filho a conseguir dinheiro para pagar os favores da meretriz porque tem, ele próprio, interesse em passar uma noite com ela. Para tanto, manda vender os asnos da mulher - daí o título da peça. Como se pode notar, este é completamente diferente do argumento d'Os Vilhalpandos, em que o motivo do contrato é o centro de uma das intrigas, a que identificamos como a segunda.

A personagem do jovem apaixonado, que protagoniza a primeira intriga - 0 tipo adulescens, figura constante nas comédias latinas, pois quase todas têm como tema central um desencontro amoroso - é quase trágica. Sofre tanto por amor que chega a pensar em suicídio. Sá de Miranda tirou proveito dessa situação que ocorre também na mesma peça de Plauto, como mostram os exemplos:

Vilhalpandos (II, 2):

Cesarião: - ... Mulheres não falecem, mas amor e contentamento são os que falecem; pera que é perder tempo andando? Vejamos o que por hoje se pode aviar; tanto que não, i está êsse Tibre, que tem mortas outras muitas sêdes neste mundo. Assi fará a esta minha.

Asinaria (III, 3):

Argiripo: - Bene uale: apud Orcum te uidebo. Nam equidem me iam quantum potest a uita abiudicabo. ("Adeus, te vejo no outro mundo. Pois já decidi privar-me da vida o quanto antes.")

Assaz distante da atitude patética do jovem Cesarião está a do capitão Vilhalpando, que representa um dos tipos de maior comicidade do teatro clássico, o miles gloriosus - o soldado fanfarrão, vaidoso, orgulhoso, que vive proferindo bravatas sob a adulação de um parasita. Exemplificamos com um diálogo entre Milvo, o parasitus, e o miles Vilhalpando (III, 1):

Vil.: - Quebrarei dez lanças d'armas no canto daquela sua casa.

Mil.: - Um Rolão! 
Vil.: - Lançar-m'-ei em terra e erguer-m'-ei, armado de ponto em branco.

Mil.: - Quem fez nunca tal?

Vil.: - Saltarei em um cavalo sem pôr pé na estribeira.

Mil.: - Ligeireza!

Vil.: - Bafordarei por cima daquela torre.

Mil.: - Galantarias!

O miles está presente em outras comédias plautinas, além do Miles gloriosus. Em Terêncio, é encontrado no Eunuchus, de onde trazemos um diálogo muito semelhante ao do exemplo acima, pelo mesmo tipo de bravatas proferidas pelo miles e o mesmo tipo de apoio nas respostas do parasitus, e que representa a mesma situação: o miles é desprezado pela meretrix. Esta passagem do Eunuchus $(\mathrm{IV}, 7)$ pode ter inspirado a cena de Sá de Miranda:

\section{Eunuchus: ${ }^{271}$}

Trasão: - O quê, eu suportar uma afronta tão grande, Gnatão? [...] Primeiro vou tomar de assalto a casa.

Gnatão: - Muito bem!

Trasão: - Depois vou arrebatar a moça.

Gnatão: - Magnífico!

Trasão: - A Taís, dou-lhe uma surra.

Gnatão: - Bravo!

Mas é em Menaechmi que encontramos o outro paradigma dos soldados Vilhalpandos, afinal, é com esta peça de Plauto que o paratexto que é o título dialoga. Surpreenderia se estes textos não dialogassem dentro da peça. Na comédia plautina encontra-se uma cena muito semelhante à d'Os Vilhalpandos. É a cena em que os simillimi se encontram. Embora a alusão não se faça por paráfrases ou citações, sabemos que é com este hipotexto que o hipertexto mirandino se relaciona já pela identificação dos protagonistas: na peça de Plauto eles são identificados como Menecmo I e Menecmo II, assim como os mirandinos são Vilhalpando I e Vilhalpando II:

${ }^{271}$ Tradução de Aires Pereira do Couto, op. cit., p. 102. 
Vilhalpandos (IV, 8):

$[\ldots]$

Vilhalpando II: - Que zombarias são estas, ou que borracharias?

Vilhalpando I: - As zombarias e borracharias são as dessa casa, que de fora não se fala senão muita verdade.

Vilhalpando II: - Que tu és o capitão Vilhalpando?

Vilhalpando I: - E tu nega-lo?

Vilhalpando II: - Salvo se tu és eu.

Vilhalpando I: - Tu vê quem és, que eu sam o capitão Vilhalpando, conhecido na guerra dos grandes e dos pequenos.

$[\ldots]$

Menaechmi $(\mathrm{V}, 10):^{272}$

$[\ldots]$

Menecmo II: - Que raio de história é essa?

$[\ldots]$

Menecmo I: - Ora essa! [...] O meu nome é Menecmo.

Menecmo II: - Homessa! Menecmo chamo-me eu!

Menecmo I: - Eu cá sou siciliano, de Siracusa.

Menecmo II: - Mas é aí que eu moro, é essa aminha terra.

Menecmo I: - Que estás tu para aí a dizer?!

Menecmo II: - A verdade verdadíssima.

$[\ldots]$

Uma outra situação em que está envolvido o miles Vilhalpando na comédia de Sá de Miranda, em que é preciso chamar à porta de uma casa, encontra paralelos em La Lena e I Suppositi, de Ariosto, e também em Bacchides. N'Os Vilhalpandos, o soldado pede a um pagem que bata à porta (IV, 8):

Vil.: - Page, bate a essa porta.

Pag.: Tá, tá, tá.

${ }^{272}$ Tradução de Carlos A. L. Fonseca. PLAUTO. Os dois Menecmos. Coimbra: INIC, 1983, p. 104. 


\section{$[\ldots]$}

Vil.: - Bate bem. Hás dó da porta?

Pag.: - Não hei senão da minha mão.

Em La Lena (IV, 3), é Bartolo (um credor) quem pede a um guarda que bata à porta:

Bar.: Guarda, venha adiante e faça o seu serviço: bate naquela porta.

Gua.: Por que devo bater nela, se ela não me fez nada? ${ }^{273}$

I Suppositi (IV, 3) traz dois velhos, Filogono e um ferrarense, frente à porta:

Fil.: - Bate.

Fer.: - Ninguém responde.

Fil.: - Bate mais uma vez.

Fer.: - Creio que estão dormindo

Fil.: - Se esta porta fosse tua mãe, não teria maior respeito ao bater ...

E em Bacchides (IV, 1), é o parasita que manda um escravo chamar à porta:

Par.: - ...Tu, rapaz, tu que já veio antes com ela aqui, qual é sua casa, ande, chame à porta, venha, depressa, chegue perto da porta e chame. Vai-te já daqui, maldito! Isso é maneira de chamar, infame! ${ }^{274}$

Da Asinaria (I, 1), Sá de Miranda parafraseou ainda uma fala do senex Demêteno e a colocou na voz do seruus Antonioto $(I, 3)$ :

Dem.: - Si quid te uolam ubi eris? (Se eu quiser algo de ti, onde estarás?)

Ant.: - ... mas onde te acharei que certo seja?

Não identificamos nehuma autocitação. Auto e intratextualidade são formas de relação intertextual usadas pelos antigos e pelos imitadores renascentistas que

${ }^{273}$ ARIOSTO. La Lena, a cura di Guido Davico Bonino. Torino: Einaudi, 1976, p. 49.

${ }^{274}$ Op. cit., p. 241. 
podem produzir interessantes efeitos de sentido. Sá de Miranda não as utilizou em nenhuma de suas duas comédias.

Sabemos que a comédia Os Vilhalpandos tem bases na Asinaria, mas também em outros textos, especialmente os terencianos já mencionados. É, contudo, a comédia plautina que mais chama a atenção e que mais facilmente se reconhece nela. A Asinaria é também a comédia que mais transparece em La Lena, de Ariosto. Curiosamente, Os Estrangeiros é fundado em outra peça de Ariosto, I Suppositi. E tanto nestas duas comédias de Ariosto quanto nas duas de Sá de Miranda, a sociedade, com seus maus costumes, é que aparece como protagonista. Todas essas coincidências fazem crer que o poeta português, inspirado em La Lena, foi buscar as fontes de Ariosto para criar Os Vilhalpandos.

\subsubsection{A caricatura da sociedade}

Evocar a Asinaria, buscar o mote da prostituição, tem como efeito de sentido criticar o desregramento que se via em Roma, onde até o Papa tinha amantes (lembremos somente do caso de Lucrecia Bórgia, amante do pai, que foi Papa, e do irmão, César). Ariosto, em La Lena, como em outras de suas obras, é mais humano, faz que todos se perdoem. Sá de Miranda, severo, faz punir todos os "pecadores". Ao retomar a Asinaria, voltando à fonte de Ariosto, Sá de Miranda presta um tributo ao poeta italiano, mas, também, rivaliza com o modelo plautino, amplificando defeitos de caráter das personagens. Esta é uma interpretação possível. Mas o poeta português pode ter desejado mostrar justamente que não concordava com o modo como Ariosto usou o modelo plautino, e foi diretamente à fonte, para reutilizála como acreditava convir.

De qualquer forma, tanto o poeta italiano como o português usaram o gênero cômico para caricaturar toda a sociedade de uma só vez. Se a máscara cômica exagera um defeito, a deformação de um caráter particular, como uma caricatura, é a face de toda a sociedade corrompida pela força do dinheiro e entregue aos prazeres e às mãos de videntes e curandeiros que os comediógrafos vão caricaturar. 
A comédia tem uma função fundamentalmente moralizante e regeneradora. Ao expor, criticando, as mazelas sociais, a comédia clássica toma ares de farsa aristofânica e quer corrigir os vícios de um grupo e não mais de um caráter individual. E é ao aludir a esses vícios que ela faz refletir no palco a imagem da platéia.

A crítica aparece em diversos trechos da peça. A mais violenta é a que o autor dirige aos membros da Igreja e aos maus costumes, em geral. Na cena 1 do ato III, Vilhalpando procura Milvo, que Ihe fora bem recomendado, para contratar seus serviços de alcoviteiro:

Mil.: - Que o não digo por me estar gabando; mas quem as manda todas e governa, senão Milvo?

Vil.: - Assi me dizem, que já venho a ti por fama.

Mil.: - Não puderas topar em toda a Roma com homem que te assi aviasse e desenganasse.

Vil.: - Nem tu com quem te assi pagasse: que estes clérigos todos são avarentos.

Mil.: - Não pera estas obras de misericórdia corporais.

Em IV, 3, é o velho Pompónio que, desconsolado, faz refletir sua indignação:

Pom.: - ¿Que farei, onde me acoutarei? Aos amigos? Donde os acharei eu? Às casas de oração? E aí que há muita hipocresia!

Em I, 1, lembra a venda de indulgências promovida pela Igreja, na voz dos velhos Mário e Pompónio:

Már.: - Foi tempo que mandavam lavar as pecados com lágrimas!

Pom.: - Agora todos com aquela água que chamam moeda..${ }^{275}$

\footnotetext{
${ }^{275}$ Informa a nota ao pé da página que estas linhas foram cortadas pela censura eclesiástica na edição de 1622.
} 
Em I, 3, o criado Antonioto negocia com o alcoviteiro Milvo uma cortesã para seu jovem amo Cesarião, que substitua Aurélia, a meretrix por quem está apaixonado:

Mil.: - E havia-te de estar vendendo a dinheiro perigos e trabalhos? A minha gente toda é mansa; mas tenho de muitas sortes, assi como aqui há muitas sortes d'apetitos.

ao que Antonioto responde ironicamente - e a lembrar que não se trata de Portugal:

Ant.: - Ah! esquecia-me que estávamos em Roma!

Em III, 8, a crítica à corrupção vai no diálogo entre Vilhalpando, que é soldado espanhol e fala como o invasor, e Milvo, que, aparentemente, representa o pensamento de Sá de Miranda

Vil.: - Nós outros com arcabuzes às costas! Aqui ficam os dez mil, ali os vinte mil, e Roma sempre em seus prazeres! Deixa, que seu dia lhe virá como a seus vizinhos.

Mil.: -É um couto do mundo.

Vil.: - Nós o devassaremos cedo, sem tanto "escreve cá, escreve lá". Cursores vão, cursores vem, ${ }^{276}$ com suas varinhas na mão, de mais virtudes que as que chamam de condão.

ao que Milvo retruca ironicamente.

Mil.: - É uma cidade de paz.

Sá de Miranda defende-se das más interpretações pela voz do criado Antonioto, em I, 4, que mostra um certo orgulho das coisas de Portugal, onde, supõe-se, estas coisas não acontecem:

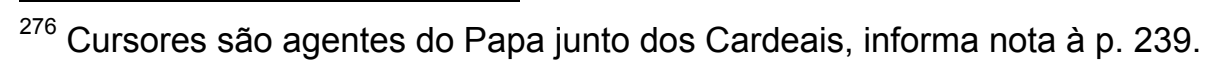


Ant.: - Oh! doudinho de Antonioto, como havias mester curado desta tua cabeça! Cuidavas pola ventura que estavas em Portugal, onde todo o negócio é suspirar e dizer saudades? Torna em ti, e lembre-te onde estás.

A presença de um ermitão, contratado para desfazer o que quer que tenha amarrado o jovem Amente àquela paixão pela meretrix, faz evocar os nigromantes de Ariosto e Bibbiena, a lembrar as práticas supersticiosas da sociedade - consta que reis e papas tinham seus nigromantes e astrólogos particulares e não tomavam qualquer decisão importante sem antes consultá-los. Também as beguinas que acompanham a matrona Fausta, com suas mezinhas e simpatias, remetem a essas práticas, que o velho Pompónio abomina (IV, 3):

Pom.: - ... Té os ermitães do ermo me saqueam a casa! Se foram soldados, aquele é o seu ofício, mas ermitães? Dum descalço, barbudo, todo coberto de seu capelo, quem se havia de temer? Despois, culpam os velhos de suspeitosos. Que faremos de tanta maldade como cada dia vemos?

Pompónio representa a austeridade, a moralidade, a que todos fogem. Talvez represente também o alter ego do poeta.

Lembramos que as críticas que Sá de Miranda apresenta em suas comédias já constavam nas comédias italianas: ao dinheiro como senhor do mundo, aquele que governa e corrompe a sociedade e suas instituições, em Ariosto; à corrupção do clero e à venda de indulgências, em Maquiavel, que coloca um frade como personagem para representar toda aquela categoria; às crendices e superstições, em Ariosto e Bibbiena, em especial, com seus nigromantes, mas também na Mandrágora, planta que dá título à peça e que, segundo o falso médico, traria a fertilidade à puritana jovem esposa do tolo doutor.

A imitação do modelo italiano permite, cremos, que Sá de Miranda lance sua própria crítica. Dirigindo-a à degradação dos costumes em Roma, pode tê-la usado de forma alegórica para criticar o desregramento que percebia em seu próprio país. 
Infelizmente, não é possível fazer qualquer afirmação a esse respeito, só nos é dado conjeturar. 


\section{CONCLUSÃO}

As comédias de Sá de Miranda são um retrato de sua civilização, da sociedade em que viveu e de suas instituições, dos costumes, das atribulações e das contradições do começo do século XVI, matéria do Capítulo 1 desta dissertação. As crises que abalaram o período na Europa refletem-se nas páginas da literatura de uma geração de poetas, à qual pertenceu, que se caracterizou - parafraseando Spina - não só por se filiar a uma tradição cultural e estética, mas pela atitude crítica diante da realidade que a circundava.

O período foi, sem dúvida, propício para o desenvolvimento da comédia, gênero que permite ridicularizar os vícios, caricaturar os viciosos, censurar ironicamente idéias, costumes, pessoas e instituições - matéria para sátira não faltava, pelo contrário, era abundante.

A retomada de textos clássicos e a sua reelaboração criativa surge como princípio poético, mas também como pretexto para expressar o desconcerto daquele mundo. Temas e tipos da comédia da Antigüidade entram em cena para representar não somente uma cultura e um ideal estético considerados excelentes, mas para refletir a vida e o mundo contemporâneo. A meretrizes e soldados, vêm juntar-se nigromantes e doutores, todos membros daquela sociedade e integrantes daquela realidade. A influência dos mistificadores e o poder corruptor do dinheiro sobre os homens, que aumentava juntamente com a expansão comercial e territorial, vêm somar-se ao rol de temas a serem tratados na comédia.

Não se tratava, pois, de reproduzir fielmente os modelos de uma tradição, que, embora se mantivessem como fonte de imitação e paradigma de excelência, não seriam muito mais do que o mote para a elaboração de obras inéditas, de teor atualizado, na prosa vulgar, local e contempoânea. Assim os trataram os poetas italianos daquele começo de século. Assim reproduziria os modelos antigos e sincrônicos Sá de Miranda, primeiro poeta em toda a Europa a seguir as pegadas dos renascentistas italianos. 
Mesmo que em novo contexto, trata-se ainda da composição de uma literatura baseada em textos precedentes, de um modo de compor aludindo a outros textos e do restabelecimento de uma poética própria, voltada para a reelaboração criativa de textos exemplares.

Como ficou exposto no Capítulo 2 de nossa dissertação, esta é a principal característica da literatura clássica, ter como princípio de criação poética a apropriação intencional de textos precedentes. O poeta que compõe sob esse princípio aceita sua condição de imitador e a imitação como regra. O processo de recriação poética que os romanos antigos denominaram imitatio envolve o emprego pelo poeta de fórmulas e convenções próprias de cada gênero por ele retomado e o empréstimo de partes de textos - que podem variar no tamanho -, de temas e de conteúdos, que, com novo arranjo e em novo contexto, virão a compor um texto inédito. A liberdade poética é limitada, mas a imitatio não impede que o poeta seja criativo e pratique o jogo alusivo engenhosamente. Ele pode criar artifícios para driblar as limitações do processo e as restrições impostas por cada gênero em particular, reelaborando criativamente o modelo.

Para tornar próprio um texto que retoma e fazer da sua uma imitação bem sucedida, o poeta precisa aprofundar-se no universo de significações do texto imitado, trazendo-as para o texto novo e a elas somando os sentidos que a mudança de contexto e as modificações aplicadas ao modelo geram. O poeta pode brincar com as alusões, recriando o modelo de diversos modos, mas a imitação bem sucedida supõe o reconhecimento pelo leitor de todo esse processo de apropriação, supõe que o leitor tome parte no jogo alusivo, relacionando a obra literária com a(s) outra(s) obra(s) literária(s) que ela evoca e percebendo os sentidos gerados pelo diálogo intertextual, porque é com a sua participação que o processo alusivo se completa.

Também de diversos modos o poeta consegue escapar às restrições do gênero. Através de modificações ou de rearranjo dos topoi próprios do modelo, ou ainda da introdução no modelo de topoi ou de idéias dele desvinculadas, como sugere Cairns, ${ }^{277}$ o poeta pode mostrar-se inovador.

${ }^{277}$ Citado no nosso Capítulo 2. 
Todos esses artifícios foram usados pelos poetas do Renascimento italiano e podem ser observados em suas composições, especialmente no que diz respeito à arquitextualidade, relação intertextual mais facilmente percebida por um leitor não tão erudito, pois que não implica na percepção de sutilezas alusivas. É nesse aspecto do processo criativo que verificamos as maiores inovações. Os italianos introduziram no gênero novos temas, novos tipos, criaram novos topoi, todos tomados à realidade que os circundava, somando-os aos antigos, que Ihes serviram de mote para a criação de novos textos. Além disso, acrescentaram ao rol de modelos exemplares textos da sua própria tradição literária, que forneceram mais temas e mais matéria para ser usada na prática alusiva.

A herança clássica que recebeu Sá de Miranda passa primeiro pelos mãos dos poetas renascentistas italianos, que the imprimem a sua marca e the agregam valores. Assim, o poeta português torna-se um herdeiro mais rico, que também vai tentar deixar sua marca para a posteridade.

A primeira comédia mirandina, Os Estrangeiros, tem por modelo, principalmente, I Suppositi, de Ariosto, onde o poeta vai buscar o motivo da jovem que é prometida em casamento a um homem mais velho e bem estabelecido na vida - o tipo "doutor", criado por Ariosto - mas está apaixonada por um jovem, que lhe corresponde a paixão. Existe, porém, um impedimento que torna a relação entre os dois jovens impossível.

A segunda comédia, Os Vilhalpandos, cujo motivo da mãe alcoviteira, que vende os "favores" da filha, a princípio, parece ter sido inspirado diretamente na Asinaria, de Plauto, pode ter sido inspirado em La Lena, de Ariosto, que retoma o tipo lena da Asinaria e recria a alcoviteira, não como mãe, mas como preceptora da jovem que deseja corromper. Nossa hipótese confirma-se pela observação de que Sá de Miranda se apropria de outros elementos do método de composição e do próprio produto da recriação de Ariosto - ele já tinha extraído o tema de sua primeira comédia de I Suppositi e apropriado-se do tipo "doutor" -, como a composição em prosa, a amarração de fragmentos provenientes de comédias diversas, entremeados de alusões a assuntos locais e contemporâneos, somados à crítica aos costumes e, em especial, à corrupção entre os membros da lgreja. 
Mas apesar de acreditarmos que a comédia Os Vilhalpandos tenha sido inspirada em La Lena, pelos motivos que acabamos de expor, reconhecemos que Sá de Miranda foi, sim, ao texto original de Plauto. Pela tradução do texto original da Asinaria, em latim, e pela observação da recriação que dela fez Ariosto, podemos afirmar que os trechos que remetem à Asinaria, retomados por Sá de Miranda, foram traduzidos e citados, quase sempre, literalmente do texto latino, como demonstramos em nossa análise. Nossa conclusão é que o poeta português recorre à comédia plautina depois de passar pela italiana. Ele vai buscar as fontes de Ariosto para, então, escrever sua comédia.

Muitos hão de concordar se dissermos que as tentativas de imitação do gênero cômico por Sá de Miranda não foram bem sucedidas. Outros tantos discordarão e sairão em sua defesa citando a tamanha erudição que transparece em seus textos. Admitimos que Sá de Miranda buscou exercitar sua criatividade e imprimir inovações ao modelo, a começar pela tentativa de aperfeiçoar o tipo "doutor" de Ariosto - no que é bem sucedido, a nosso ver. Ele apresenta um novo tema - o dos estrangeiros - e faz pequenas alterações em outros, amplia o defeito de um tipo, diminui o de outro, fazendo-os servir aos seu propósitos moralizantes e, ainda, introduz no modelo clássico um elemento da tradição portuguesa: as esparsas do capitão Vilhalpando. Todas as inovações referentes à arquitextualidade de suas comédias parecem-nos terem tido bom êxito. Mas quando ele tenta construir o seu texto seguindo o modo de compor de Ariosto, como "mosaico de citações", se perde em meio ao excesso de contaminação e o diálogo intertextual fica comprometido pela falta de sentidos. O resultado final da obra faz lembrar o exemplo que dá Horácio, no início da Epístola aos Pisões, do pintor que mistura elementos díspares para compor uma figura única.

Se a finalidade do jogo alusivo é gerar sentidos pela evocação de textos e contextos anteriores e não simplesmente adornar um texto novo com citações de outros textos, Sá de Miranda não obteve êxito. Talvez o poeta tenha realmente tomado a empresa de compor comédias regulares como passatempo, como exercício intelectual, sem a preocupação de contribuir com inovações para o enriquecimento da "arte alusiva". Talvez nem tenha tido essa pretensão. 
A nosso ver, o valor literário da comédia mirandina reside em ser iniciadora de um gênero e de um movimento artístico em Portugal. Mas há nela também um outro valor, que é o de refletir no texto a imagem do mundo de seu tempo, um valor histórico e documental de uma época, como já o afirmaram muitos. Cabe-nos, aqui, reiterar a afirmação. 


\section{BIBLIOGRAFIA}

\section{I - Sá de Miranda}

SÁ DE MIRANDA, Francisco de, Obras Completas / Francisco de Sá de Miranda. Texto fixado, notas e prefácio pelo prof. M. Rodrigues Lapa. 2. ed. Lisboa: Livraria Sá da Costa, 1942-1943. (Coleção de Clássicos Sá da Costa).

. Poesia e teatro / Sá de Miranda. Introdução, seleção e notas por Silvério Augusto Benedito. Lisbon: Biblioteca Ulisseia de Autores Portugueses, 1989.

BRAGA, Teófilo. Sá de Miranda e a Eschola Italiana. Porto: Livraria Chardron, 1896.

EARLE, Thomas F. Rhetoric and Drama: the two versions of Sá de Miranda's Os Estrangeiros. In: Culture and society. Ed. by Niguel Griffin et al. London:Tanesis, 2001.

Sá de Miranda's Roman Comedy. In: Cultural links between Portugal and Italy Renaissance. Ed. K. J.P. Lowe. Oxford: Oxford University Press, 2000.

. The Comedy of The Foreigners: Renaissance Sicily through Portuguese eyes. Oxford: Claredon Press, 1997.

- Traição e Amargura nas comédias de Francisco de Sá de Miranda. In:

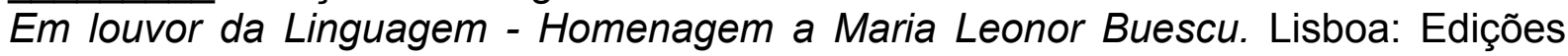
Colibri, 2003.

FRANCO, Marcia Arruda. Duas versões da dedicatória de Os Estrangeiros, de Sá de Miranda. Trabalho apresentado no $2^{\circ}$ Colóquio do PPRLB, em abril de 2004. Disponível em: <www.realgabinete.com.br/coloquio/autor.asp?indice=45>.

REMÉDIOS, J. Mendes dos. As comédias de Sá de Miranda. Revista da Universidade de Coimbra. Coimbra: Imprensa da Universidade, v. 10, p. 1038-1076, 1933.

\section{II - Da Cultura, Literatura e Teatro Portugueses}

BRAGA, Teófilo. História da Literatura Portuguesa / II - Renascença. Lisboa: Publicações Europa-América, [19-]. 
BUESCO, M. L. Carvalhão. Aspectos da herança clássica na cultura portuguesa. Lisboa: Instituto de Cultura Portuguesa - Secretaria de Estado da Cultura, 1979. (Biblioteca Breve, v. 33).

CAMÕES. Teatro Camoniano I - Enfatriões. Prefácio e notas de Vieira de Almeida. Lisboa: Editorial Império, 1942.

Autos. Anotado por Marques Braga. Lisboa: Imprensa Nacional, 1928.

. Auto dos Anfitriões de Camões. Apresentação crítica, estabelecimento do texto, notas e sugestões para análise literária de Clara Rocha. Lisboa: Seara Nova, 1981.

El-Rei Seleuco. Introdução, notas e glossário de Augusto C. Pires de Lima. Porto: Editorial Domingos Barreira, 1960.

CARVALHO, Joaquim Barradas de. Estudos sobre a Cultura Portuguesa do século XVI. Coimbra: [s.n.], 1947, v. 1.

CIDADE, Hernani. Lições de Cultura e Literatura Portuguesa (séculos XV, XVI e XVII). 7. ed. Coimbra: Coimbra Editora, 1984, v. 1.

FERREIRA, António. Obras Completas do doutor Antonio Ferreira. 4. ed., anotada e precedida de um estudo sobre a vida e obras do poeta pelo Cônego Doutor J. -C. Fernandes Pinheiro. Rio de Janeiro: Garnier, 1865, tomo 2.

FIGUEIREDO, Fidelino de. Historia da Litteratura Clássica: $1^{a}$ Epocha: 1502 - 1580. 2. ed. Lisboa: Livraria Clássica Editora, 1922.

GIL VICENTE. Auto da Índia / Auto da Barca do Inferno / Farsa de Inês Pereira. Apresentação e notas por Benjamin Abdala Junior. São Paulo: SENAC, 1996.

MOISES, Massaud. A literatura portuguesa através dos textos. São Paulo: Cultrix, 1991.

As Estéticas Literárias em Portugal - séculos XIV a XVIII. Lisboa: Editorial Caminho, 1997.

PICCHIO, Luciana Stegagno. História do Teatro Português. Lisboa: Portugália Editora, 1964.

REBELLO, Luiz Francisco. História do Teatro Português. Lisboa: Publicações Europa-América, 1967.

REBELO, Luís de Sousa. A Tradição Clássica na Literatura Portuguesa. Lisboa: Livros Horizonte, 1982. 
ROIG, Adrien, O teatro clássico em Portugal no século XVI. Lisboa: Instituto de Cultura e Língua Portuguesa - Ministério da educação, 1983. (Biblioteca Breve, v. 76).

SARAIVA, António José. Para a História da Cultura em Portugal. 4. ed. Lisboa: Publicações Europa-América, 1972, v. 1.

SILVEIRA, Francisco Maciel (Seleção e Introdução). Poesia clássica: literatura portuguesa. São Paulo: Global, 1988.

VASCONCELOS, Jorge Ferreira de. Comédia Eufrosina. Conforme a impressão de 1561, publicada por ordem da Academia da Sciências de Lisboa por Aubrey F. G. Bell. Lisboa: Imprensa Nacional de Lisboa, 1918.

\section{III - Da Cultura, Literatura e Teatro Latinos}

CAIRNS, Francis. Generic Composition in Greek and Roman Poetry. Edinburgh: Edinburgh University Press, 1972.

CARDOSO, Zélia de Almeida. A Literatura Latina. Porto Alegre: Mercado Aberto, 1989.

CATULO. O Livro de Catulo. Tradução, introdução e notas de João Angelo Oliva Neto. São Paulo: Edusp, 1996.

CICERÓN. Bruto [Historia de la elocuencia Romana]. Madrid: Alianza Editorial, 2000.

CONTE, G. B. Latin Literature. A History. Baltimore: Johns Hopkins University, 1994.

COSTA, Aída. Temas Clássicos. São Paulo: Cultrix, 1978.

DUCKWORTH, George E. (Edited, and with an introduction by). The Complete Roman Drama - all the extant comedies of Plautus and Terence, and the tragedies of Seneca, in a variety of translations (in two volumes). New York: Random House, 1942.

GAILLARD, Jacques. Introdução à Literatura Latina. Lisboa: Editorial Inquérito, [s.d.].

HORÁCIO. Arte Poética. Tradução, notas e comentários de Dante Tringali. São Paulo: Musa, 1994.

LIVIO, Tito. Storia di Roma dalla sua fondazione. Vol. terzo (Libri V-VII). Note di Claudio Moreschini. Texto latino a fronte. Milano: Rizzoli Libri, 1989. 
LIVY. From the founding of the city. Vol. III (Books V-VII). With an English translation by B. O. Foster. Cambrige: Harvard University Press, London: Willian Heinemann Ltd, 1984.

MARTIN, René; GAILLARD, Jacques. Les genres littéraires à Rome, préface de Jacques Perret. Paris: Éditions Nathan, 1990.

MENDES, Andréa Cristina. O Espetáculo Tearal Romano e a peça Otávia. Monografia de Mestrado. São Paulo, DLCV-FFLCH-USP, 2001.

OLIVA NETO, João Angelo. Falo no Jardim: Priapéia grega, Priapéia latina. Tese apresentada para obtenção de título de Doutor junto ao Departamento de Letras Clássicas e Vernáculas da Faculdade de Filosofia, Letras e Ciências Humanas da USP. São Paulo, 1999.

ORAZIO. Tutte le opere. Versione, introduzione e note di Enzio Cetrangolo. Firenze: Sansoni Editori, 1988.

PARATORE, Ettore. História da Literatura Latina. Lisboa: Fundação Calouste Gulbenkian, 1983.

PLAUTO. Comedias - Anfitrión - La Comedia de los Asnos - La Comedia de la Olla Las Dos Báquides - Los Cautivos - Cásina, Tomo I. Introducciones, traducción y notas de Mercedes Gonzáles-Haba. Madrid: Editorial Gredos, 1992.

. Comédias - O cabo, Caruncho, Os Menecmos, Os prisioneiros, 0 soldado fanfarrão. Seleção, introdução, notas e tradução direta do latim por Jaime Bruna. São Paulo: Cultrix, 1978.

. Tutte le commedie - Amphitruo, Asinaria, Aulularia, Bacchides, a cura di Ettore Paratore, testo latino a fronte. Roma: Grandi Tascabili Economici Newton, 1992.

. Anfitrião. Introdução, versão do latim e notas de Carlos Alberto Louro Fonseca. Lisboa: Edições 70, 1993.

. Aulularia. Tradução, introdução e notas da Profa Aída Costa. São Paulo: Difusão Européia do Livro, 1967.

Epídico. Introdução, versão do latim e notas de Walter de Souza Medeiros. Coimbra: Instituto Nacional de Investigação Científica/Centro de Estudos Clássicos e Humanísticos da Universidade de Coimbra, 1980.

Lisboa: Edições 70, 1999.

Tradução, introdução e notas de Walter de Medeiros. 
. La casa del fantasma. Introduzione di Cesare Questa, traduzione di Mario Scandola, testo latino a fronte. Milano: Biblioteca Universale Rizzoli, 1983.

. Os dois Menecmos. Introdução, versão do latim e notas de Carlos Alberto Louro Fonseca. Coimbra: Instituto Nacional de Investigação Científica/Centro de Estudos Clássicos e Humanísticos da Universidade de Coimbra, 1983.

O Soldado Fanfarrão. Tradução, prefácio e notas de Carlos Alberto Louro Fonseca, coleção O Grande Teatro do Mundo. Coimbra: Atlântida, 1968.

- Persa. Introdução, tradução do latim, notas e sugestões para encenação por Maria Isabel Rebelo Gonçalves. Lisboa/SãoPaulo: Verbo, 1999.

PLAUTO e TERÊNCIO, A Comédia Latina: Anfitrião - Aulularia - Os Cativos - O Gorgulho - Os Adelfos - O Eunuco. Prefácio, seleção, tradução e notas de Agostinho da Silva. Rio de Janeiro: Tecnoprint, 1967.

TÁCITO. Anais. Tradução e prólogo de Leopoldo Pereira. Rio de Janeiro: Ediouro, [s.d.].

TÉRENCE. Andrienne - Eunuque. Tome I, texte établi et traduit par J. Marouzeau, Paris: Belles Lettres, 1947.

. Heautontimorumenos - Phormion. Tome II, texte établi et traduit par J. Marouzeau, Paris: Belles Lettres, 1964.

TERÊNCIO. A moça que veio de Andros. Introdução, versão do latim e notas de Walter de Medeiros. Coimbra: Instituto Nacional de Investigação Científica/Centro de Estudos Clássicos e Humanísticos da Universidade de Coimbra, 1988. (Textos Clássicos, 29).

. O homem que se puniu a si mesmo. Introdução, tradução e notas de Walter de Medeiros. Coimbra: Instituto Nacional de Investigação Científica/Centro de Estudos Clássicos e Humanísticos da Universidade de Coimbra, 1993. (Textos Clássicos, 35).

O Eunuco. Introdução, tradução do latim e notas de Aires Pereira do Couto. Lisboa: Edições 70, 1996. (Coleção Clássicos Gregos e Latinos).

Formião. Introdução, tradução do latim e notas de Aires Pereira do Couto. Lisboa: Edições 70, 1999. (Coleção Clássicos Gregos e Latinos).

. Os dois irmãos. Tradução, versão do latim e notas de Walter de Souza Medeiros. Coimbra: Instituto Nacional de Investigação Científica/Centro de Estudos Clássicos e Humanísticos da Universidade de Coimbra, 1983. (Textos Clássicos 14). 
. A Sogra. Introdução, versão do latim e notas de Walter de Medeiros. Brasília: Editora da Universidade de Brasília, 1994.

- Comédias: Ândria - Eunuco - Heautontimorumenon - Adelfos. Tradução clássica portuguesa de Leonel da Costa Lusitano, introdução de José Pérez. São Paulo: Edições Cultura, 1945. (Série Clássica Universal).

TRINGALI, Dante. Horácio poeta da festa: navegar não é preciso: 28 ODES. São Paulo: Musa, 1995. (Coleção Ler os Clássicos, v. 3).

WRIGHT, John. Dancing in chains: the stylistic unity of the Comoedia Palliata. Rome: American Academy, 1974.

\section{IV - Da Cultura, Literatura e Teatro Gregos}

ARISTÓFANES. Comedias: Los caballeros, La paz, Las avispas, Pluto. Tomo segundo. Traducción de R. Martinez Lafuente. Valencia: Prometeo, [s.d.].

As Vespas. As Aves. As Rãs. Tradução do grego, introdução e notas de Mário da Gama Kury. Rio de Janeiro: Jorge Zahar, 1996.

- Duas comédias: Lisístrata e As Tesmoforiantes. Tradução, apresentação e notas de Adriane da Silva Duarte. São Paulo: Martins Fontes, 2005.

Lisístrata e As Nuvens. Tradução e nota introdutória de Millôr

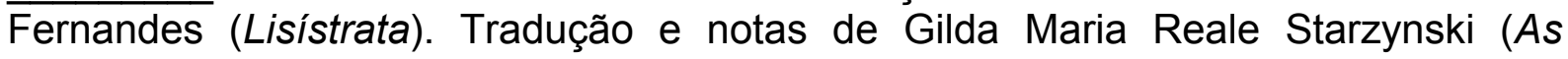
Nuvens). São Paulo: Abril Cultural, coleção Teatro Vivo, 1977.

; MENANDRO. A Paz - O Misantropo. Tradução do grego, introdução e notas de Mário da Gama Kury. Rio de Janeiro: Ediouro, [s.d.].

ARISTÓTELES. Ética a Nicômaco. Tradução de Pietro Nassetti. São Paulo: Martin Claret, 2005.

. Poética. Tradução de Eudoro de Souza. São Paulo: Ed. Abril, 1984. (Coleção Os Pensadores).

Tradução, prefácio, introdução, comentário e apêndices de Eudoro de Souza. Porto Alegre: Globo, 1966.

. Retórica das Paixões. Introdução, notas e tradução de Isis Borges B. da Fonseca. São Pauo: Martins Fontes, 2000. 
; HORÁCIO; LONGINO. A poética clássica. Introdução por Roberto de Oliveira Brandão; tradução direta do grego e do latim por Jaime Bruna. 12. ed. São Paulo: Cultrix, 2005.

DUARTE, Adriane da Silva. Comédia Grega Antiga: Temas e Personagens. Palestra apresentada na Faculdade de Letras da UFMG em 28/06/2000.

HOMERO. Batracomiomaquia. Estudo e tradução de Fabrício Possebon. São Paulo: Humanitas, 2003.

Ediouro, 2001, 2 v.

llíada /Odisséia. Tradução de Carlos Alberto Nunes. Rio de Janeiro:

JANKO, Richard. Aristotle on comedy: towards a reconstruction of Poetics II. Los Angeles: University of California Press, 1984.

MENANDRO. Comedias. Introducciones, traducciones y notas por Pedro Bádenas de La Peña. Editorial Gredos: Madrid, 1986.

(Classici Greci e Latini).

Commedie. A cura di Guido Paduano. Milano: Oscar Mondadori, 2004.

TEOFRASTO. Caracteres. Introducciones, traducciones y notas por Elisa Ruiz Garcia. Madrid: Editorial Gredos, 1988.

ZAGAGI, Netta. The Comedy of Menander - Convention, Variation \& Originality. London: Duckworth, 1994.

\section{V - Da Cultura, Literatura e Teatro Italianos}

ALIGHIERI, Dante. Le rime. Milano: Garzani, 1979.

Cultural, 2002.

A Divina Comédia. Tradução de Fábio M. Alberti. São Paulo: Nova

ARIOSTO, Ludovico. II negromante/El nigromante. Introducción, traducción y notas de Maria Teresa Navarro Salazar. Barcelona: Bosch, 1976.

Mursia, 1997.

Commedie: La Cassaria - I Suppositi. A cura di Luigina Stefani. Milano: . La Lena, a cura di Guido Davico Bonino. Torino: Einaudi, 1976.

. Orlando Furioso. Introdução, tradução e notas de Pedro Garcez Ghirardi. Cotia: Ateliê, 2002. 
Scolastica. Premessa di Roberto Trovato. Bologna: Arnaldo Forni, 1978.

; MACHIAVELLI; BIBBIENA. Obras primas do Teatro Italiano (século

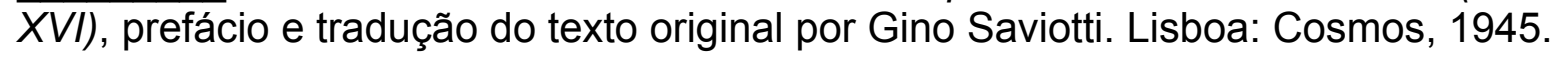

BLASI, G. de. L'Ariosto e le passioni. Giornale Storico della Letteratura Italiana CXXX, 1953.

BORSELLINO, Nino. Ludovico Ariosto. Bari: Editori Laterza, 1996.

1996.

; MERCURI, Roberto. II Teatro Del Cinquecento. Bari: Editori Laterza,

CROCE, B. Ludovico Ariosto. La Crítica - Rivista di lettratura, storia e filososfia. Diretta da B. Croce, v. XV. Bari: Gius. Laterza 7 Figli, editori, 1917.

DE SANCTIS, Francesco. Storia della Letteratura Italiana. Torino: UTET, 1968.

GAREFFI, Andréa. Ludovico Ariosto. Firenze: Giunti \& Lisciani Editori, 1995.

MAQUIAVEL. A Mandrágora - Belfagor, o Arquidiabo. Tradução de Pietro Nassetti. São Paulo: Martin Claret, 2004.

MARTI, Mario. Profilo della Critica Ariostesca. In: Letteratura Italiana - I Maggiori. Milano: Marzorati, 1975.

PETRARCA. O Cancioneiro. Tradução, introdução e notas de Jamil Almansur Haddad. Rio de Janeiro: Ediouro, [s.d.].

SCOLARI, Antonio. Ludovico Ariosto. Firenze: Le Monnier, 1903.

SILVA, Martha F. Maldonado Baena da. O teatro renascentista italiano: alguma luz sobre o teatro de Ariosto. Lumen - Revista de Estudos e Comunicações. São Paulo: IESP/UNIFAI, 2006. (Edição especial - Anais IV Simpósio Multidisciplinar do Centro Universitário Assunção).

TASSO, Torquato. Aminta. Introduzione di Mario Fubini, note di Bruno Maier, premessa al testo, cronologia e bibliografia di Ettore Barelli, con le incisione settecentesche di P. A. Novelli. Milano: Rizzole, 2002.

Barbèra, 1872.

. La Gerusalemme Liberata. Per cura di Domenico Carbone. Firenze: G.

TORRACA, Francesco. Gli "Studenti" di Ludovico Ariosto - studio critico. Padova: La Garangola, 1929. 


\section{VI - Intertextualidade}

BAKHTIN, Mikhail. Problemas da Poética de Dostoievski. 3. ed. Rio de Janeiro: Forense Universitária, 2002. . Marxismo e filosofia da linguagem. 7. ed. São Paulo: Hucitec, 1995.

BARROS, Diana Luz P. de; FIORIN, José Luiz (orgs.). Dialogismo, Polifonia, Intertextualidade. São Paulo: Edusp, 1994.

BONANNO, Maria Grazia. L'Allusione necessaria. Ricerche intertestuali sulla poesia greca e latina. Roma: Ateneo, 1990.

BOUCHÉ, Claude. Lautréamont: du lieu commun à la parodie. Paris: Larousse, 1974. (Thèmes et Textes).

CONTE, G. B. The Rhetoric of Imitation: Genre and Poetic Memory in Virgil and Other Latin Poets. Ithaca and London: Cornell University Press, 1996.

CORRADIN, Flávia Maria. Antônio José da Silva: textos versus (con)textos. Cotia: Íbis, 1998.

ECO, Umberto. Interpretação e Superinterpretação. São Paulo: Martins Fontes, 2005.

EDMUNDS, Lowell. Intertextuality and the reading of Roman poetry. Baltimore: Johns Hopkings University Press, 2001.

GENETTE, Gérard. Palimpsestes - la litttérature au second degré. Paris: Seuil, 1982.

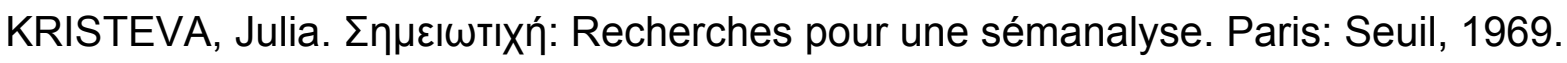
. Introdução à semanálise. São Paulo: Perspectiva, 1974.

MORA, Carlos de Miguel (coord.). Sátira, paródia e caricatura: da Antiguidade aos nossos dias. Aveiro: Universidade, 2003.

ORLANDI, E. P. Terra à vista. Discurso do confronto: velho e novo mundo. São Paulo: Cortez, 1990.

;; GUIMARÃES, E. Unidade e dispersão: uma questão do texto e do sujeito. In: ORLANDI, E. P. et al. Sujeito e texto. São Paulo: EDUC, 1988, p. 17-36. (Série Cadernos PUC). 
PASQUALI, Giorgio. Arte Allusiva. In: Stravaganze - Quarte e Supreme. Venezia: Neri Pozza, 1951.

PÊCHEUX, Michel. Semântica e discurso. Uma crítica à afirmação do óbvio. Campinas: Ed. da UNCAMP, 1988.

POSSEBON, Frabício. Capítulo 3: Riso; Capítulo 4: Intertextualidade. In: HOMERO. Batracomiomaquia. São Paulo: Humanitas, 2003, p. 47-77.

SANT'ANNA, Affonso Romano de. Paródia, paráfrase \& Cia, 7. ed. São Paulo: Ática, 2001.

VASCONCELLOS, Paulo Sérgio de. Efeitos Intertextuais na Eneida de Virgílio. São Paulo: Humanitas, 2001.

WEST, David \& WOODMAN, Tony (edited by). Creative Imitation and Latin Literature. Cambridge-London-New York-Melbourne: Cambridge University Press, 1979.

VII - Geral

ALBERTI, Verena. O riso e o risível na história do pensamento. Rio de Janeiro: Jorge Zahar, 2002.

ARÊAS, Vilma. Introdução à Comédia. Rio de Janeiro: Jorge Zahar, 1990.

AUERBACH, Erich. Mimesis. 4. ed. São Paulo: Perspectiva, 1998.

BAKHTIN, Mikhail. A cultura popular na Idade Média e no Renascimento. 5. ed. São Paulo: Hucitec, 2002.

BENDER, Ivo C. Comédia e riso: uma poética do teatro cômico. Porto Alegre: Ed. Universidade//UFRGS/EDPUCRS, 1996.

BERGSON, Henri. O riso. Tradução de Ivone Castilho Benedetti. São Paulo: Martins Fontes, 2004.

BERTHOLD, Margot. História Mundial do Teatro. São Paulo: Perspectiva, 2001.

Cadernos de Literatura e tradução, n. 6. São Paulo: Humanitas FFLCH / USP, 2005.

Chartularium Universitatis Portugalensis (1288-1536). Editado por Francisco da Gama Caeiro, António Domingues de Sousa Costa e outros. Lisboa: Instituto Nacional de Investigação Científica, vol. 10, 1991-9, p. 386-7. 
CURTIUS, E. R. Literatura Européia e Idade Média Latina. Tradução de Teodoro Cabral e Paulo Rónai. São Paulo: Hucitec: Edusp, 1996.

MANGUEL, Alberto. Lendo Imagens: uma história de amor e ódio. Tradução de Rubens Figueiredo, Rosaura Eichemberg, Cláudia Strauch. São Paulo: Companhia das Letras, 2001.

MENÉNDEZ PELAYO. Historia de las ideas estéticas en España. Vol. I e II. Buenos Aires: Espasa-Calpe, 1943.

MOISES, Massaud. A Criação Literária. São Paulo: Melhoramentos, 1968. . Dicionário de termos literários. 2. ed. rev. São Paulo: Cultrix, 1978.

MOUSSINAC, Léon. História do Teatro - das origens aos nossos dias. Tradução de Mário Jacques. Amadora: Livraria Bertrand, [s.d.].

PAVIS, Patrice. Dicionário de Teatro. São Paulo: Perspectiva, 1999.

PROPP, Vladímir. Comicidade e Riso. Tradução de Aurora Fornoni Bernardini e Homero Freitas de Andrade. São Paulo: Ática, 1992.

ROJAS, Fernando de. La Celestina. 3. ed. Madrid: Ediciones Cátedra,1976.

. A Celestina. Tradução de Walmir Ayala, a partir da adaptação de Luís Escobar e Humberto de la Ossa. Rio de Janeiro: Francisco Alves, 1988.

ROVISCO, Miguel. Uma Comédia de Quinhentos (Adaptação da comédia Os Vilhalpandos de Sá de Miranda), 1986. (Reprodução do documento original, Sociedade Portuguesa de Autores).

SHAW, Harry. Dicionário de termos literários. 2. ed. Lisboa: Dom Quixote, 1982.

SPINA, Segismundo. A cultura literária medieval. 2. ed. rev. São Caetano do Sul: Ateliê, 1997. . Introdução à Poética Clássica. São Paulo: F.T.D., 1967.

TOUCHARD, Pierre-Aimé. Dioniso: apologia do teatro: seguido de $O$ amador de teatro ou A regra do jogo. São Paulo: Cultrix, 1978.

1970.

. O teatro e a angústia dos homens. São Paulo: Livraria Duas Cidades,

VASCONCELLOS, Luiz Paulo. Dicionário de Teatro. São Paulo: L\&PM Editores S/A, 1987. 


\section{VIII - Obras de referência}

AMENDOLA, João. Dicionário italiano-português. 2. ed. rev., ampl. e atualizada conforme a nova ortografia em vigor. Prefácio de Mário Moretti. São Paulo: HEMUS, 1976.

DEZOTTI, Maria Celeste C. Miniléxico Grego-Português. Araraquara: FLC-UNESP, 2000.

FARIA, Ernesto. Dicionário escolar latino-português. 2. ed. Rio de Janeiro: Ministério da Educação e Cultura, 1956.

FLORENZANO, Everton. Dicionário Ediouro espanhol-português, portuguêsespanhol. 34. ed. Rio de Janeiro: Ediouro, 1999.

. Dicionário Ediouro francês-português, português-francês. 17. ed. Rio de Janeiro: Ediouro, [s.d.].

KURY, Mário da Gama. Dicionário de mitologia grega e romana. 5. ed. Rio de Janeiro: Jorge Zahar, 1999.

Michaelis - Dicionário Prático Inglês-Português - Português-Inglês. São Paulo: Melhoramentos, 2000.

RODRIGUES, André Figueiredo. Como elaborar e apresentar monografias. São Paulo: Humanitas, 2005. (Coleção Metodologias, v. 3)

. Como elaborar citações e notas de rodapé. 2. ed. ampliada. São Paulo: Humanitas, 2005. (Coleção Metodologias, v. 2)

. Como elaborar referência bibliográfica. 5. ed. rev. e ampl. São Paulo:

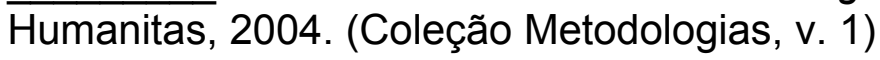

SARAIVA, F. R. dos Santos. Novíssimo Dicionário Latino-Português. 11. ed. Rio de Janeiro: Livraria Garnier, 2000. 


\section{APÊNDICE A}

\section{Manuscrito Asensio - BNL}

\section{Edição semidiplomática: $\|1 \mathrm{r} \cdot\|^{278}$ francisco $\cdot$ de $\cdot$ sa .}

carta sua $A$ o infante dom anrique

No que $\cdot$ Vossa $\cdot$ Alteza $\cdot$ manda naõ ha que dizer [mais] ${ }^{279} \cdot$ qual ha co | media he tal uai aldeam mal ataviada - fiz lhe soomẽte | duas lembrãças asua partida · huã que fizese o coraçaõ [tam] larguo | pera atera a que hia $\cdot$ omde lhe muito [cõprỷhaa] $\%$ outra que | nũca se desculpase de querer a lugares · aremedar plauto e | teremçio \% antes aquẽ lhe tanta honra fizese sempre h[e] a | gradeçase muito $\cdot$ e tomase ẽ lugar de gramde louuor / tam | bem ariosto natural de ferrara - omẽ nobre demũitas letras e | demuito engenho · en huã sua comedia Jtaliana asimesmo | en prosa · meteo apesoa duũ doutor \% mas diguo eu · que se loguo | por iso fora defesso atodos fazer outro tamto - não ouuera | nas comedias antigas tamtos ẽ guanos descravos - tamtos | pais apertados · filhos prodýguos . solldados baõs / quãto | maJs que ariosto não foỷ o prỷmeiro /. Jaa detres avogados · | ẽ teremçio - huũ afirma outro negua e outro douỷda / | Jaa tulio ameaçaua seu amiguo trebaçio, tamãnho Jures · cõ | sulto cõ as graças delaberỷo \% eveio todauia acair nas de ho | raçio os comẽtos me perdoem que al cuidaraõ $\%$ asi que a [in] | venção amtigua he · aJnda que o titolo de doutor nã seJa am | tiguo ${ }^{280}$. nẽ daquele comedimẽto que foi o de filosofo\%/ mas | Jlustre senhor he como dizem andar polas ramas - que muỷ levemente | pudera pasar aper da deste trabalho $\cdot$ e mũito maJs ado louvor $/ \cdot \mid$ o trabalho tomei por meu pasatenpo · asi como algũs caçam | outros Jogam / no louuor nũca cuidei $/ /$ o de que sem[pre] ouve | medo · foraõ maas Jntrepetações a que senão pode fugir | em nenhuuã maneira // tanto quehos Jreges Jntrepetamdo | mal todos querẽ fundar seus eros na sagrada escritura $\mid$ e 0 diabo $/ \cdot$ tanbem a Jsto ouvera dous remedỷos/· naõ escrever | e dormir meu sono em cheo e o milhor he o segũdo · pois jaa | não podia dormir como oraçio diz fora romper ou queỷ | mar tudo · este measegurou depois ao tenpo da neçesidade | amigos me forçaraõ dele/· o coraçaom damiguos foỷ | [fól. 2] as maõs medo eỷ que mesaỷam dimiguos . saluo se vosa | alteza mandar enparar os estrangeiros · por seus como sam | ou ao menos por estrangeiros - em que senpre se enpregua | bem ho enparo / enpurtugues escreuem poucos - nesta maneyra | descreuer aJnda ninguẽ que eu saiba $\%$ aos que começaõ he / divido perdam polo prouerbio greguo / eu cõ perdam soo | me cõtentareỷ \#\#\# /// fim da carta $\cdot / /$.

\footnotetext{
${ }^{278}$ No alto da mancha, à direita, constam as seguintes informações, feitas por outra mão: numeração de página: <118>; e procedência do documento: <Cópia da edição de | 1559, embora com ligeiras | modificações. | [ilegível] Cat. Palha, 1218>. Este manuscrito corresponde à versão impressa da edição de 1559, a qual se encontrava na Biblioteca de Fernando Palha, antes de ir para a de Harvard. Acreditamos que "Cat. Palha" signifique "Catálogo Palha", referindo-se à biblioteca de onde procede o texto.

${ }^{279}$ Rasurado no manuscrito, mas a leitura é possível.

${ }^{280}$ Há um borrão entre as letras $i$ e $g$ da palavra amtiguo.
} 


\section{APÊNDICE B}

\section{Manuscrito Asensio - BNL}

Edição modernizada: $\|1 \mathrm{r}\|. F \cdot d \cdot S$.

Carta sua ao Infante Dom Henrique

No que Vossa Alteza manda não há que dizer mais. Qual a comédia é tal vai aldeã e mal ataviada. Fiz-lhe somente duas lembranças a sua partida: uma que fizesse o coração tão largo para a terra a que ia, onde lhe muito cumpria; outra que nunca se desculpasse de querer a lugares arremedar Plauto e Terêncio. Antes a quem lhe tanta honra fizesse sempre e agradecesse muito e tomasse em lugar de grande louvor. Também Ariosto, natural de Ferrara, homem nobre de muitas letras e de muito engenho, em uma sua comédia italiana, assim mesmo em prosa, meteu a pessoa de um doutor. Mas digo eu que se logo por isso fora defeso a todos fazer outro tanto, não houvera nas comédias antigas tantos enganos de escravos, tantos pais apartados, filhos pródigos, soldados bons. Quanto mais que Ariosto não foi o primeiro. Já há de três advogados em Terêncio: um afirma, outro nega e outro duvida. Já Túlio ameaçava seu amigo Trebácio, tamanho jurisconsulto, com as graças de Labério, e veio todavia a cair nas de Horácio, os comentos me perdoem, que de outra coisa cuidaram. Assim que a invenção antiga é, ainda que o título de doutor não seja antigo, nem daquele comedimento que foi o de filósofo, mas, ilustre senhor, é como dizem andar pelas ramas, que mui levemente pudera passar a perda deste trabalho e muito mais a do louvor. O trabalho tomei por meu passatempo, assim como alguns caçam, outros jogam. No louvor nunca cuidei. $O$ de que sempre houve medo foram más interpretações a que se não pode fugir em nenhuma maneira, tanto que os hereges, interpretando mal, todos querem fundar seus erros na sagrada escritura e o diabo. Também a isto houvera dois remédios: não escrever e dormir meu sono em cheio e o melhor é o segundo, pois já não podia dormir como Horácio diz: fora romper ou queimar tudo. Este me assegurou depois ao tempo da necessidade, amigos me forçaram dele. O coração de amigos foi, | [fól. 2] as mãos medo hei que me saiam de inimigos, salvo se Vossa Alteza mandar amparar Os Estrangeiros por seus como são, ou ao menos por estrangeiros, em que sempre se emprega bem o amparo. Em português escrevem poucos, nesta maneira de escrever ainda ninguém que eu saiba. Aos que começam é devido perdão pelo provérbio grego, eu com perdão só me contentarei. Fim da carta. 